Claremont Colleges

Scholarship@ Claremont

CGU Theses \& Dissertations

CGU Student Scholarship

2013

\title{
The Use of Financial Statements to Predict the Stock Market Effects of Systemic Crises
}

Mohammad Yahia Almakrami

Claremont Graduate University

\section{Recommended Citation}

Almakrami, Mohammad Yahia, "The Use of Financial Statements to Predict the Stock Market Effects of Systemic Crises" (2013). CGU Theses \& Dissertations. Paper 85.

http://scholarship.claremont.edu/cgu_etd/85

DOI: $10.5642 /$ cguetd $/ 85$

This Open Access Dissertation is brought to you for free and open access by the CGU Student Scholarship at Scholarship @ Claremont. It has been accepted for inclusion in CGU Theses \& Dissertations by an authorized administrator of Scholarship @ Claremont. For more information, please contact scholarship@cuc.claremont.edu. 


\title{
THE USE OF FINANCIAL STATEMENTS TO PREDICT THE STOCK MARKET EFFECTS OF SYSTEMIC CRISES
}

\author{
By
}

\author{
Mohammad Almakrami
}

A Dissertation submitted to the Faculty of Claremont Graduate University in partial fulfillment of the requirements for the degree of Doctor of Philosophy in Economics.

Claremont Graduate University

2013

(c) Copyright Mohammad Almakrami, 2013

All rights reserved. 


\section{APPROVAL OF THE REVIEW COMMITTEE}

This dissertation has been duly read, reviewed, and critiqued by the Committee listed below, which hereby approves the manuscript of Mohammad Almakrami as fulfilling the scope and quality requirements for meriting the degree of Doctor of Philosophy in Economics.

Thomas D. Willett, Chair Claremont Graduate University Horton Professor of Economics

Thomas Borcherding Claremont Graduate University

Professor of Economics

Levan Efremidze Claremont Graduate University Adjunct Professor of Economics 


\begin{abstract}
The Use of Financial Statements to Predict the Stock Market Effects of Systemic Crises By

Mohammad Almakrami

Claremont Graduate University: 2013
\end{abstract}

The financial crisis of 2007-2009 had divesting effects around the globe. Many financial institutions and government officials failed to see the build up of problems predicting the crisis and hence failed to take actions to keep the crisis from breaking out. Thus, it is important to see if the emerging problems could have been identified in advance in order to develop types of analysis that could help us avoid future crises. A full investigation of such possibilities will require many different studies taking different approaches. This dissertation contributes to that collective effort by investigating the extent to which balance sheet information could have been used to identify the emerging problems. We implement our research strategy by analyzing what types of balance sheet information did the best job of explaining how hard different major financial institutions were hit during the crisis.

We constructed a large data set of financial variables from the financial reports of financial institutions over the years 2002 to 2011 . We used this data to developed models to predict the damage to an individual firm when a systemic crisis occurred based on its financial position and performance over varying time periods and relative to 
other institutions' characteristics. We used changes in stock market prices as our measure of performance. We found that the financial leverage ratio and the mismatch between current assets and current liabilities are the most significant ratios to predict the degree of stock market declines each institution would face if a systemic crisis occurred. We quantified the degree of the financial leverage and current ratios in two different ways, an average level and accumulated time-weighted rate of change over different lags of periods using two different estimation techniques. We found that the financial leverage and current ratios can be used as early warning signals based on both the multivariable fractional polynomials estimation technique and structural equation modeling. However, the out-of-sample tests showed that the imbalance between current assets and current liability would be the only significant predictor of the changes in stock market prices. The test confirmed that the changes in pre-crisis stock prices are less sensitive to the leverage ratio but more sensitive during crisis. 


\section{Dedication}

$\mathcal{T}_{0}$ my Parents and Wife 


\section{ACKNOWLEDGEMENT}

A special thank goes to my Dissertation Chair and Academic Advisor Prof. Thomas Willett, who has been a helpful in every stage of the process of completing this dissertation by advising, suggesting, and offering feedback. With his supervision, patience, kindness, and guidance, my research skills have been substantially improved and this dissertation has been constructed to see the light in its final shape.

I am also extremely grateful to my committee members Prof. Thomas Borcherding and Dr. Levan Efremidze for agreeing to serve on my Dissertation committee. Their suggestions and comments from the beginning to the end helped shape the scope and content of the Dissertation. I am also very indebted to friends, colleagues, and staff at Claremont Graduate University.

I want to thank my father Yahia Almakrami and my mother Karama Almakrami for the sacrifices they made during my life long and their spiritual guidance throughout the duration of my education. Also my siblings (Abdullah, Hiba, Hussain, Haider, Ali, Esmae'el, and Saif) and my children (Jihan, Laila, Bandar, Fajer, and Fatima) deserve special thanks for their support and love.

Last but not least, a very special thank goes to my lovely wife Jawaher Almakrami for standing with me through all the years of suffering particularly during the period of writing this dissertation. Her patience, support, judgment, and debating through the development of this dissertation from time to time inspired me and pushed me to complete this dissertation. 


\section{Table of Contents}

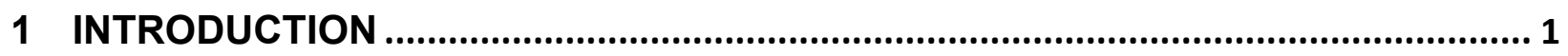

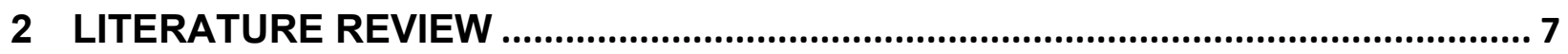

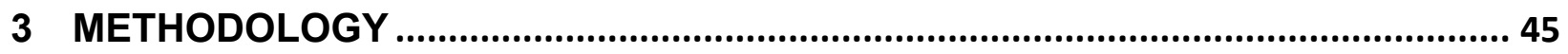

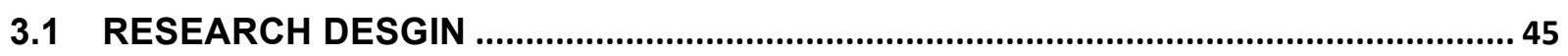

3.2 RATIONALE FOR A QUANTITATIVE FRAMEWORK ............................................. 45

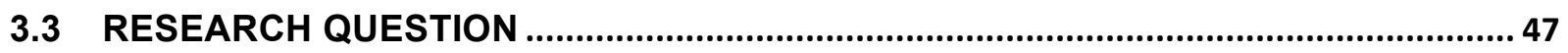

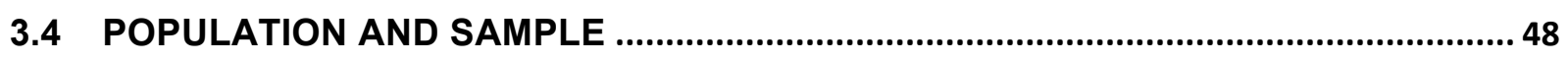

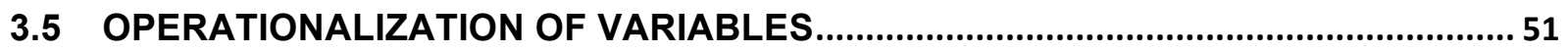

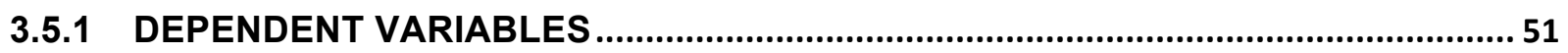

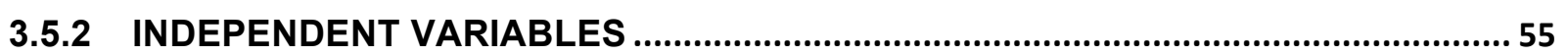

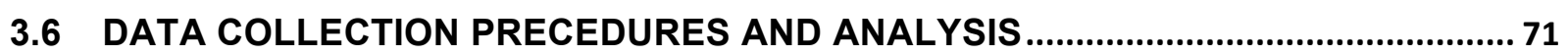

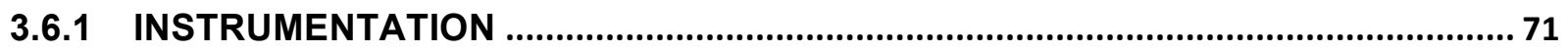

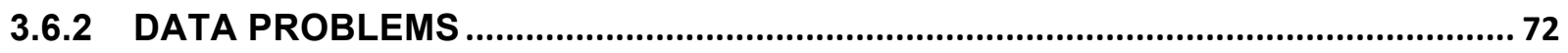

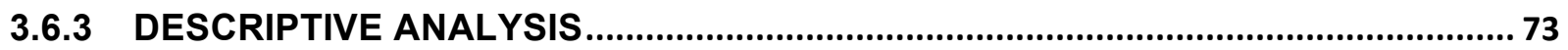

4 EMPERICAL ANALYSIS BASED ON STRUCTURAL EQUATION MODELING ... 74

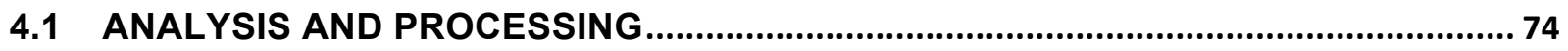

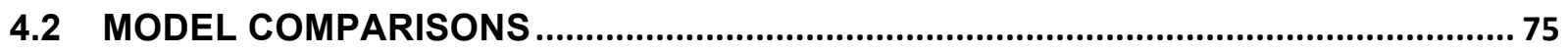

5 EMPERICAL ANALYSIS BASED ON MULTIVARIABLE FRACTIONAL

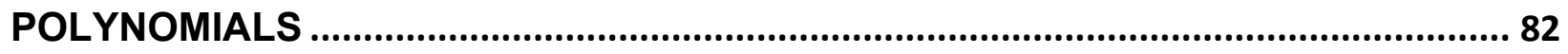

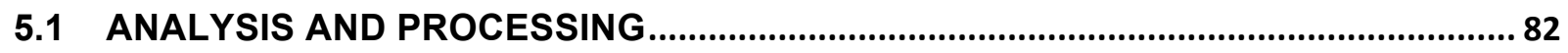

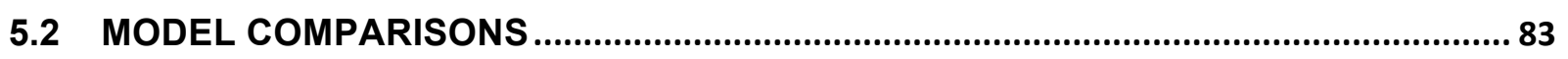

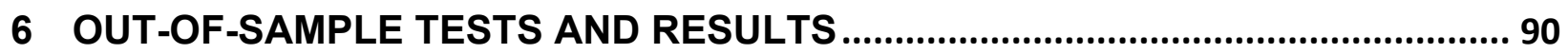

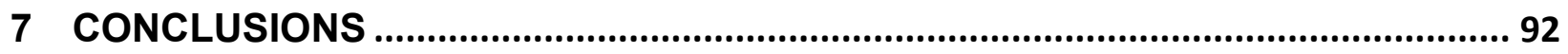

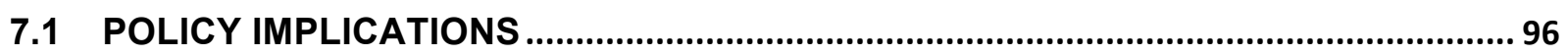

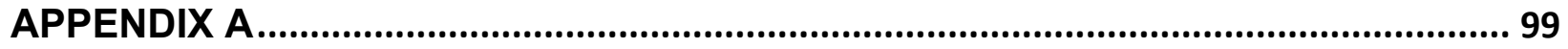

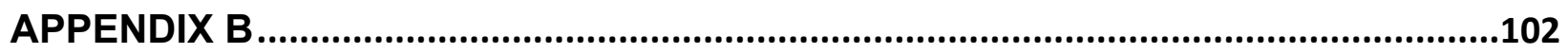

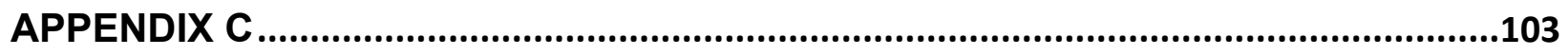

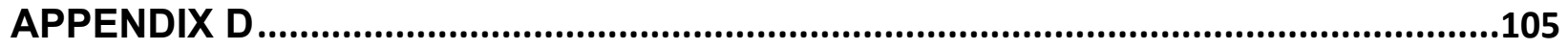

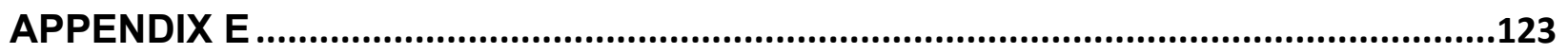

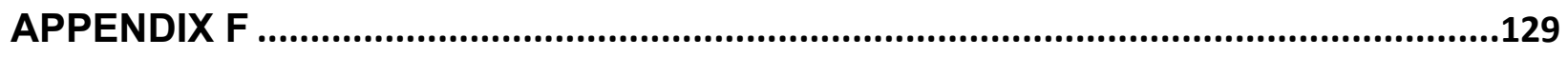

REFERENCES 


\section{INTRODUCTION}

The financial crisis of 2007-2009 had divesting effects around the globe. Many financial institutions and government officials failed to see the build up of problems predicting the crisis and hence failed to take actions to keep the crisis from breaking out. Thus, it is important to see if the emerging problems could have been identified in advance in order to develop types of analysis that could help us avoid future crises. A full investigation of such possibilities will require many different studies taking different approaches. This dissertation contributes to that collective effort by investigating the extent to which balance sheet information could have been used to identify the emerging problems. We implement our research strategy by analyzing what types of balance sheet information did the best job of explaining how hard different major financial institutions were hit during the crisis.

We constructed a large data set of financial variables from the financial reports of financial institutions over the years 2002 to 2011 . We used this data to developed models to predict the damage to an individual firm when a systemic crisis occurred based on its financial position and performance over varying time periods and relative to other institutions' characteristics. We used changes in stock market prices as our measure of performance. We found that the financial leverage ratio and the mismatch between current assets and current liabilities are the most significant ratios to predict the degree of stock market declines each institution would face if a systemic crisis occurred. We quantified the degree of the financial leverage and current ratios in two different ways, an average level and accumulated time-weighted rate of change over 
different lags of periods using two different estimation techniques. We found that the financial leverage and current ratios can be used as early warning signals based on both the multivariable fractional polynomials estimation technique and structural equation modeling. However, the out-of-sample tests showed that the imbalance between current assets and current liability would be the only significant predictor of the changes in stock market prices. The test confirmed that the changes in pre-crisis stock prices are less sensitive to the leverage ratio but more sensitive during crisis. By examining each firm's financial records by themselves, we can analyze indicators deviating from the norm from those financial reports as potential key warning signs. Additionally, due to the massive scale of such a systemic event, it is appropriate to test the outcomes against leading variables in order to understand how multinational firms identified in this study were affected.

The most significant factor that emerged during the economic growth period predating the crisis related to issues of mispricing financial risks. Due to the nature of these risks, serious flaws existed in the financial models that were used to calculate the risk of securities such as market-backed securities (MBS) and credit default swap (CDS). Thus undervaluing these particular risks by professionals in the field of finance and economics during that era led not only to the increase of the size and the volume of these traded securities, but also to the miscalculation of the values of balance sheet items such as assets and liabilities. Another factor related to the implementation of expansionary monetary policies by governments to stimulate economies coupled with the poor deregulation over those years which allowed financial firms to increase their leverage ratios to excessive levels (Willett, 2009). 
A third factor related to financial statements emphasizes on the impacts of the complexity and difficulties encountered by investors and users of these statements concerning their understanding and interpreting various types of risks related to the market, credit, and liquidity due to the lack of inadequate risk disclosures in financial reports. Some researchers argue that limited transparency regarding the on- and offbalance sheet items coupled with a declining economic environment will lead into disorderly market correction and inadequate market discipline, in particular during crises periods (Papa, 2011). ${ }^{1}$ All of these factors by themselves or interacting with each other boosted exposure to the counterparty defaults on obligations to unprecedented levels that an individual firm faced.

On the other hand, if a firm cannot generate cash internally via operations, it will find various channels to generate cash like issuing new shares, selling some assets, or incurring new debts. Therefore, the organization that runs a negative cash flow from operation over many years to meet basic business requirements will increase the ratio of leverage to unsustainable levels. Ultimately, on an aggregated basis, the whole market exposed to an extreme amount of shortfall of capital as a result of these defaults makes a good recipe for a crisis.

There is significant debate among scholars regarding every essential aspect involved in crisis analysis. First, scholars disagree on an appropriate measure for the

\footnotetext{
${ }^{1}$ Disorderly market correction refers to how the market adjusts during the crisis event when a state of economic is declining. The shortage of liquidity forces financial institutions to sell a large amount of their assets or to raise new debts to meet their obligations, and that incurs them with high cost when spreads are high. Inadequate market discipline refers to mispricing the different types of risks such as market, credit, and liquidity risk and accordingly misallocation of capital, in particular, when it combines with declining economic environment. For more details see Papa (2011).
} 
dependent variable that can accurately quantify the effect of financial crisis on an individual institution. Second, there is a conflict regarding the independent variables whether leading indicators should associate with financial reports or macroeconomic factors or both. The third controversy concerns assessing the impacts of this crisis on firms through investigating a set of indicators over varying lags of periods. For example, an early study implemented by Beaver (1967) found that a cash flow measure was the most significant variable to predict firms' bankruptcy, while another study conducted by Altman (1968) found other financial ratios related to profitability, performance, and solvency were the most significant indicators to predict firms' bankruptcy. Adrian and Brunnermeier (2011) used financial ratios to attempt to measure systemic risk and to predict the individual institution's participation to that risk found a set of balance sheet ratios were significant as leading indicators, while a study completed by Acharya, Pedersen, Philippon, and Richardson (2010) found the ratio of leverage was the only ratio to have made a significant contribution to predict firms' contribution to the systemic risk.

Another area of controversy that has emerged among researchers relates to the implementation of various types of methodologies and techniques when assessing the incidence of financial crises. The most common method is the use of linear regression or logistic regression to predict outcome of a categorical dependent variable. The aim of these approaches is to test the statistical significance of diverse indicators in defining the occurrence or the probability of occurrence of a financial crisis through a crosssection of firms or countries. Secondly, the non-parametric method starts by selecting control variables for a crisis which then determines threshold levels of these variables 
when it gives statistically significant results beyond those levels. The problem with this approach is that the threshold level determined within a sample and the significant results might not hold when conducted on out-of-sample tests. Another approach uses qualitative and quantitative analysis for the performance of indicator variables around the time the crisis occurred by making a crisis group and non-crisis group. This kind of analysis is based on panel analysis where the researchers try to predict the time of a crisis rather than analyzing the incidence at one point of time as cross-sectional does.

By taking all these controversies into account, the primary contribution that this dissertation makes to the existing literature is that rather than focusing upon how and why this financial crisis originated in the U.S., we concentrate upon a set of intervening variables critical the effective performance of financial institutions and examine the outcome of those intervening variables and what firms will suffer the most based upon their pre-crisis performance.

Additionally, we investigate which firms proved most vulnerable during the crisis by using two different estimation techniques including structural equation modeling and multivariable fractional polynomials over various lag periods. We concentrate our study on financial statements' data between 2002 to 2011 for 52 American financial institutions on a quarterly basis, focusing on variables associated with firms' performance, profitability, and solvency. Our results indicate that the capital structure and liquidity ratios over a two years lag period are the most significant indicators in determining the impact of a crisis on firms' stock market prices. 
The study takes the following format; chapter two is a review of literature. Chapter three introduces the methodology of the study and how the variables were operationalized. Chapter four presents the empirical study and analysis using structural equation modeling estimation technique. Chapter five presents the empirical study and analysis using multivariable fractional polynomials estimation technique. Chapter six presents our analysis and results using the out-of-sample tests. Finally, Chapter seven summarizes conclusions and offers recommendations. 


\section{LITERATURE REVIEW}

The primary objective of this study is to calculate the expected changes in the prices of stocks in the scenario of when a financial crisis hits the financial market based on the fundamental characteristics of financial firms that are related to profitability and sustainability over different periods of time.

The literature has introduced different models to measure the expected change in stock prices or asset returns starting from single-factor to multiple factor models in an attempt to measure and control risk associated with the changes in these different factors. The one single-factor model is commonly referred to as the Capital Asset Pricing Model (CAPM) otherwise known as the market model that was introduced by Jack Treynor in 1962 (French, 2003). This model assumes that all of the variation in stock prices is fully explained by a single factor, the systematic risk that shows the sensitivity of each stock price to the market index, and eliminates other factors such as inflation or interest rates, which might have their own impacts on asset returns. The market model, which takes into account only systematic risk, has shown an incomplete explanation of risks (Bodie, Gray, and Merton, 2001).

Multifactor models can be characterized as fundamental macroeconomic or microeconomic models depend on the type of factors used. Macroeconomic multifactor models build upon the surprises, the differences between actual and expected values. An early study showed macroeconomic variables that significantly explain the variations in stock prices were associated with firms' expected cash flows directly or indirectly via interest rate effects (Chen, 1986). The Arbitrage Pricing Theory (APT) describes the expected change in price as a linear function of the risks associated with different macro 
factors. Burmeister and McElroy showed that we might reject the market model in favor of a multifactor-model such as APT at the 1 percent level of significance (Burmeister and McElroy, 1988).

The fundamental microeconomic models are constructed on the characteristics of stocks that can significantly explain cross-sectional differences between firms' stocks based on changes in factors such as market capitalization, size, and financial leverage. The model pioneered by Eugene Fama and Kenneth French (Fama, 1992), which is commonly referred to as the Fama-French model, adds two factors associated with market capitalization and book-to-market ratio to the market model in order to provide a more detailed analysis of risk than CAPM does. The changing nature of different risk factors makes these factors act differently over stable and unstable economy. These different scenarios lead to violate the assumptions behind models such as CAPM. For example, the market model assumes that lending and borrowing will be at a risk free rate for all firms, and the transaction cost is equal to zero. Most of the models build upon probabilities which depend mainly on market volatilities and the associated variations in stock market prices to predict the outcome of a crisis. In fact, stable and growing economy is associated with low market volatilities and a low level of correlations between firms' pre-crisis stock market prices, while these volatilities and the correlation levels between stock market prices increase to risky levels during crisis (Angkinand, Wihlborg, and Willett, 2011).

Several publications have appeared in recent years documenting a number of intervening variables that place firms at a point of vulnerability to crises including financial ratios related to performance, profitability, solvency, capital structure, and a 
firm's size. Although some of the relevant research focused upon sources of crises, the studies presented in this review converge upon a set of intervening variables pertinent to an individual firm's performance that when deviating from the norm can act as potential key warning signs. The literature presented in this study particularly introduces different models to measure the expected change in stock prices or other measures of the effects of a financial crisis.

Max Heine (2000) adapted and updated two earlier studies related to Z-Score and ZETA models for Edward Altman (1968) and Altman, Haldeman, and Narayanan (1977) respectively to assess the effectiveness of the use of financial ratios to predict a corporation's bankruptcy or a firm being under distress. Altman and his fellows, in both Z-Score and ZETA models, modified and updated two other studies; Beaver (1967) and Deakin (1972) by the use of financial ratios to predict the same outcome (firm's bankruptcy). They divided a sample of 66 firms into two groups (failed and non-failed or stressed and non-stressed) with 33 firms in each group. Altman et al. collected financial ratios data from 1946 until 1965 on a yearly basis. They categorized these ratios into five classes (liquidity, profitability, leverage, solvency, and activity). In the early works, Beaver (1967) used univariate technique but Deakin (1972) continued evaluating the same 14 financial ratios used by Beaver but adapted a series of multivariate discriminant model, while Altman et al. used a multiple discriminant statistical methodology to evaluate the role of a set of financial ratios in predicting firm's bankruptcy.

Because evaluating firms' operating and financial positions is a subject to the analysis of their financial ratios, Altman attempted to fill in the gap between the use of 
traditional ratios as analytical technique and firms' performance. While, Beaver found only one single ratio of cash flow to debt as the best indicator to predict firm bankruptcy, Altman found a set of financial ratios related to performance, profitability, and solvency prevailed as the most significant leading indicators to firms' bankrupts. Altman argued that the use of univariate methodology has a possibility to produce vague results as a firm might be recognized to be headed towards bankruptcy due to poor profitability or solvency ratios while it has a better than average liquidity ratio which would make the situation appear to be not serious. ${ }^{1}$

Examining a list of 22 financial ratios, Altman examined 86 distressed firms between the years 1969 and 1975, 110 distressed firms between 1976 and 1995, and 120 distressed firms between 1997 and 1999. Altman found that the Z-score model accurately predicted a firm's bankruptcy by 82 percent and 94 percent using the cutoff score of 2.675. Altman found five ratios that prevailed as the best set of ratios to predict firm bankruptcy. The final discriminant function is as follows:

$$
\text { Z-Score }=0.012 X_{1}+0.014 X_{2}+0.033 X_{3}+0.006 X_{4}+0.999 X_{5}
$$

Where:

Z-Score $=$ the overall index

$\mathrm{X}_{1}=$ working capital/total assets

$\mathrm{X}_{2}=$ retained earnings/total assets

\footnotetext{
${ }^{1}$ Altman argued that a set of several measures with a meaningful predictive model will overcome the shortcomings of any univariate analysis. In an indication of these financial ratios should be used as analytical technique. For more detail see E. Altman (1968).
} 
$\mathrm{X}_{3}=$ earnings before interest and taxes/total assets

$\mathrm{X}_{4}=$ market value equity/book value of total liability

$\mathrm{X}_{5}=$ sales/total assets

In 1977, a revised Z-Score model introduced by changing the market value of equity with book value of equity to get:

$$
Z^{\prime} \text {-Score }=0.717 X_{1}+0.847 X_{2}+3.107 X_{3}+0.420 X_{4}+0.998 X_{5}
$$

Where:

$\mathrm{X}_{4}=$ book value equity/book value of total liability

Altman et al. (1977) introduced the 'ZETA' model by collecting data for 111 firms between 1969 and 1975 and created two groups including 53 bankrupt firms and 58 non-bankrupt firms. In this model, Altman et al. selected 28 variables with only seven financial ratios to be chosen as the most significant and reliable as a group, while the model would not be more significant if more variables were added. These financial ratios and their descriptions are shown in Table 2.1 below.

\section{Table 2.1: Description of the seven variables}

\begin{tabular}{|c|c|c|}
\hline Number & The Ratio & Description \\
\hline 1 & Return on Assets & Earnings before Interest and Taxes / Total Assets \\
\hline 2 & Stability of Earnings & $\begin{array}{l}\text { Normalized measure of the standard Error of } \\
\text { estimate around a } 5 \text { to } 10 \text { years trend in Return on } \\
\text { Assets }\end{array}$ \\
\hline 3 & Debt Service & $\begin{array}{l}\text { Earnings before Interest and Taxes / Total Interest } \\
\text { Payments }\end{array}$ \\
\hline
\end{tabular}




\begin{tabular}{lll}
\hline 4 & $\begin{array}{l}\text { Cumulative } \\
\text { profitability }\end{array}$ & Retained Earnings / Total Assets \\
5 & Liquidity & Current Assets / Current Liabilities \\
6 & Capitalization & Common Equity / Total Capital \\
7 & Size & Total Assets \\
\hline
\end{tabular}

By utilizing the ZETA model which depends upon selecting various indicators and setting threshold levels, Altman et al. increased the accuracy to 96.2 percent one period prior to bankruptcy and to 70 percent five annual periods prior to bankruptcy versus 93.9 percent and 36 percent for Z-Score model respectively. The model will signal a warning flag if these threshold levels are exceeded in a sense of that firm is facing a stress situation. ${ }^{1}$ Their results are shown in Table 2.2 below where these variables can be classified as profitability (1-6), coverage and earnings relative to leverage (8-14), liquidity (15-18) capitalization (19-23), earnings variability (24-26) and few others.

Table 2.2: Estimation results for ZETA model based on one period prior to bankruptcy

\begin{tabular}{llccc}
\hline No. & Variables & Failed & Non-Failed & $\begin{array}{c}\text { Univariate F- } \\
\text { test }\end{array}$ \\
\hline 1 & EBIT/TA & -0.0055 & 0.1117 & 54.3 \\
2 & NATC/TC & -0.0297 & 0.0742 & 36.6 \\
3 & SALES/TA & 1.3120 & 1.6200 & 3.3 \\
4 & SALES/TC & 2.1070 & 2.1600 & 0.0 \\
5 & EBIT/SALES & 0.0020 & 0.0070 & 30.2 \\
6 & NATC/SALES & -0.0153 & 0.0400 & 33.1 \\
\hline
\end{tabular}

${ }^{1}$ For more details see Altman et al. (1977). 


\begin{tabular}{llccc}
\hline 7 & LOG TANG.ASSETS & 1.9854 & 2.2220 & 5.5 \\
8 & INT COV & -0.5995 & 5.3410 & 26.1 \\
9 & LOG NO 8 & 0.9625 & 1.1620 & 26.1 \\
10 & FIXED CHARG COV & 0.2992 & 2.1839 & 15.7 \\
11 & Earnings /Debt & -0.0792 & 0.1806 & 32.8 \\
12 & Earnings 5 yr. Maturities & -0.1491 & 0.6976 & 8.8 \\
13 & Cash/Flow Fixed charges & 0.1513 & 2.9512 & 20.9 \\
14 & Cash Flow/TD & -0.0173 & 0.3136 & 31.4 \\
15 & WC/LTD & 0.3532 & 2.4433 & 6.0 \\
16 & Current Ratio & 1.5757 & 2.6040 & 38.2 \\
17 & WC/TA & 0.1498 & 0.3086 & 40.6 \\
18 & WC/Cash expenses & 0.1640 & 0.2467 & 5.2 \\
19 & Ret. Earn /TA & -0.0006 & 0.2935 & 114.6 \\
20 & BV Equity/TC & 0.2020 & 0.5260 & 64.5 \\
21 & MV Equity/TC & 0.3423 & 0.6022 & 32.1 \\
22 & 5 yrs. MV Equity/TL & 0.4063 & 0.6210 & 31.0 \\
23 & MV Equity/TL & 0.6113 & 1.8449 & 11.6 \\
24 & SD of est. EBIT/TA & 1.6870 & 5.784 & 33.8 \\
25 & EBIT drop & -3.2272 & 3.179 & 9.9 \\
26 & Margin drop & -0.2173 & 0.179 & 15.6 \\
27 & Capital lease/Asset & 0.2514 & 0.178 & 4.2 \\
28 & Sales/Fixed Assets & 3.1723 & 4.179 & 3.5 \\
\hline
\end{tabular}

Where

EBIT: Earnings before interest and taxes

NATC: Net available for total capital

TA: Total tangible assets 
LTD: Long term debt

MV: Market value of equity

TC: Total capital

TD: Total debt

WC: Working capital

CF: Cash flow

Capital structure also played a crucial role in the 2008 financial crisis. Although many of the financial institutions were in positions of meeting the minimum capital requirements that were imposed by Basel I and II, this failed to stop the panic in the financial industry promoting governments to step in to support and bail them out. ${ }^{1}$ In fact, the massive rescues of these firms have led to modifying such capital requirements through introducing Basel III by implementing a 1/N rule for leverage ratio. In 2010, Basel Committee introduced Tier I leverage ratio (i.e. 3 percent) which means an individual firm can leverage its equity up to 33 times. $^{2}$ However, the total risk-adjusted capital requirement stays the same as before (i.e. 8 percent), Tier I capital requirement will increase to 6 percent by 2019, and banks can use capital from Tier II to fill the gap between Tier I and total capital requirements. ${ }^{3}$

By assessing the relationships between various types of capital ratios and movement of stock prices before and during the 2007 crisis, Demirgus-Kunt,

\footnotetext{
${ }^{1}$ For more details see Andrew Haldane (2012), Merrouche and Nier (2010), Vinals et al. (2010), and Caprio et al. (2010).

${ }^{2}$ Andrew Haldane argued that 7 percent of leverage ratio instead of 3 percent was needed therefore large banks can survive the financial crisis in 2008. In addition, a 4 percent leverage ratio is required to minimized Type I and II crisis errors. For more details see Andrew Haldane (2012).

${ }^{3}$ For more details see Demirguc-Kunt et al (2010).
} 
Detragiache and Merrouche (2010) addressed the question of which type of capital structure ratios are more relevant to stock changes particularly during the time of crisis and how effective such capital structure can improve the bank's ability to absorb unexpected financial shocks.

Collecting financial data for 381 banks from 12 economies over the period 2005Q1 to 2009Q1, Demirgus-Kunt et al. base their analysis on two sample sets including a full sample and a sample containing only large banks that carried equal to or greater than 50 billion in assets while using dummy variables to control for pre-crisis and during-crisis periods that took a value of one from 2007Q3 to 2009Q1. DemirgusKunt et al. used the percent change in stock market prices as the dependent variable and a set of financial ratios which lagged one year as independent variables while selecting two types of capital structure as control variables in order to assess which one more effectively predicted the outcome. The first capital ratio measured the total regulatory capital (Tier I and Tier II) scaled by Basel Risk-Weighted Assets (RWR) and the second capital ratio measured the total regulatory capital scaled by total unweighted assets (Leverage). ${ }^{1}$

Demirgus-Kunt et al. find that financial leverage is more significant and reliable than risk-weighted asset ratio with respect to the sub-sample of large banks during the crisis at a one percent level but not during pre-crisis periods, while the full sample shows pre-crisis leverage ratios to be significant at the 10 percent level and RWR

\footnotetext{
${ }^{1}$ The regulatory capital includes Tier I and Tier II. Where: Tier I capital consists of shareholder funds and perpetual, non-cumulative preference shares, and Tier II capital consists of hybrid capital, subordinated debt, loan loss reserves, and valuation reserves. For more detail see Demirgus-Kunt, Detragiache, and Merrouche (2010)
} 
significant at the 10 percent level during the crisis. That tells us that the changes in precrisis stock prices are less sensitive to the leverage ratio but more sensitive during crisis. In addition, the regression results presented by Demirgus-Kunt et al. are shown in Table 2.3 which indicates that smaller decline in stock prices when the crisis hits the economy is most likely a result of institutions that were better capitalized.

Table 2.3: Estimation results for Demirgus-Kunt, Detragiache, and Merrouche (2010)

\begin{tabular}{|c|c|c|c|c|}
\hline & \multicolumn{2}{|c|}{ Full Sample } & \multicolumn{2}{|c|}{ Large Banks } \\
\hline $\begin{array}{c}\text { Independent } \\
\text { Variables }\end{array}$ & RWR & Leverage & RWR & Leverage \\
\hline Pre-Crisis: & (1) & (2) & (3) & (4) \\
\hline \multirow[t]{2}{*}{ Capital } & 0.023 & $0.078^{*}$ & -0.155 & -0.046 \\
\hline & $(0.036)$ & $(0.046)$ & $(0.102)$ & $(0.089)$ \\
\hline \multirow[t]{2}{*}{ Liquidity } & $0.016^{*}$ & 0.012 & $0.047^{* *}$ & 0.041 \\
\hline & $(0.008)$ & $(0.010)$ & $(0.022)$ & $(0.026)$ \\
\hline \multirow[t]{2}{*}{ Deposits } & 0.013 & 0.017 & 0.013 & 0.014 \\
\hline & $(0.009)$ & $(0.012)$ & $(0.014)$ & $(0.013)$ \\
\hline \multirow[t]{2}{*}{ Net Loans } & 0.001 & -0.001 & $-0.02^{*}$ & -0.012 \\
\hline & $(0.007)$ & $(0.008)$ & $(0.012)$ & $(0.012)$ \\
\hline \multirow[t]{2}{*}{ Provisions } & $-1.204^{* * *}$ & $-1.043^{* *}$ & $-1.333^{*}$ & -1.402 \\
\hline & $(0.374)$ & $(0.428)$ & $(0.76)$ & $(0.886)$ \\
\hline \multirow[t]{2}{*}{ Size } & 0.053 & 0.07 & -0.698 & -0.209 \\
\hline & $(0.070)$ & $(0.078)$ & $(0.839)$ & $(0.736)$ \\
\hline \multirow[t]{2}{*}{ MV/BV Equity } & $0.018^{* * *}$ & $0.015^{* *}$ & 0.108 & 0.093 \\
\hline & $(0.005)$ & $(0.006)$ & $(0.072)$ & $(0.075)$ \\
\hline Price-Earning & 0.000 & $-0.001^{* * *}$ & $0.009^{* * *}$ & $-0.009^{* * *}$ \\
\hline
\end{tabular}




\begin{tabular}{|c|c|c|c|c|}
\hline \multirow{3}{*}{ Beta } & $(0.000)$ & $(0.000)$ & $(0.003)$ & $(0.003)$ \\
\hline & -0.233 & -0.082 & -0.239 & -0.338 \\
\hline & $(0.242)$ & $(0.257)$ & $(0.293)$ & $(0.349)$ \\
\hline \multicolumn{5}{|l|}{ During-Crisis: } \\
\hline \multirow[t]{2}{*}{ Capital } & $0.114^{*}$ & 0.124 & 0.207 & $0.553^{* * *}$ \\
\hline & $(0.063)$ & $(0.096)$ & $(0.143)$ & $(0.194)$ \\
\hline \multirow[t]{2}{*}{ Liquidity } & $-0.037^{* *}$ & -0.037 & $0.098^{*}$ & 0.094 \\
\hline & $(0.017)$ & $(0.022)$ & $(0.056)$ & $(0.066)$ \\
\hline \multirow[t]{2}{*}{ Deposits } & $0.036^{* *}$ & $0.038^{*}$ & $0.074^{* * *}$ & $0.102^{* * *}$ \\
\hline & $(0.016)$ & $(0.020)$ & $(0.022)$ & $(0.030)$ \\
\hline \multirow[t]{2}{*}{ Net Loans } & $-0.030^{*}$ & $-0.031^{*}$ & -0.032 & $-0.073^{* *}$ \\
\hline & $(0.016)$ & $(0.018)$ & $(0.028)$ & $(0.028)$ \\
\hline \multirow[t]{2}{*}{ Provisions } & $-3.014^{* * *}$ & $-3.644^{* * *}$ & -2.947 & -2.927 \\
\hline & $(0.995)$ & $(1.076)$ & $(2.373)$ & (3.246) \\
\hline \multirow[t]{2}{*}{ Size } & -0.038 & 0.043 & -1.265 & -0.73 \\
\hline & $(0.088)$ & $(0.090)$ & $(0.830)$ & $(0.730)$ \\
\hline \multirow[t]{2}{*}{ MV/BV Equity } & 0.027 & 0.006 & 0.043 & 0.024 \\
\hline & $(0.064)$ & $(0.062)$ & $(0.070)$ & $(0.042)$ \\
\hline \multirow[t]{2}{*}{ Price-Earning } & $-0.001^{* * *}$ & $-0.001^{* * *}$ & $-0.001^{* * *}$ & $-0.001^{* * *}$ \\
\hline & $(0.000)$ & $(0.000)$ & $(0.000)$ & $(0.000)$ \\
\hline \multirow[t]{2}{*}{ Beta } & $-0.594^{*}$ & $-0.754^{* *}$ & -0.105 & 0.014 \\
\hline & $(0.350)$ & $(0.358)$ & $(0.506)$ & $(0.658)$ \\
\hline No. Obs & 4254 & 3779 & 887 & 741 \\
\hline$R^{2}$ & 0.23 & 0.23 & 0.31 & 0.32 \\
\hline
\end{tabular}

Note: ${ }^{*} p<0.05 ;{ }^{* *} p<0.01 ;{ }^{* * *} p<0.001$

Standard errors in parenthesis

Dependent Variables: the percent change in stock market price during the financial crisis from 2007q3 until 2009q1 
Berger and Bouwman (2009) examine the impact of capital structure before the 2008 crisis regarding a bank's ability to survive banking or market crises. ${ }^{1}$ By categorizing crises in the US to a banking crisis and a market crisis, Berger and Bouwman collected financial data from 1984Q1 to 2008Q4 for every commercial and credit card bank in the US (18326 banks) on a quarterly basis and created three subsamples according to the banks' sizes (small, medium, and large) ${ }^{2}$ Berger and Bouwman first used logit to assess the probability that a bank is more likely to survive a crisis. Although, they find that capital helps small banks to survive the two types of crises, they find that capital helps medium and large banks to survive a banking crisis only. The results are shown in Table 2.4 .

Second, Berger and Bouwman regress the percentage change in market share on the average level of capital ratio and same set of control variables over the same lag during or after the crisis. ${ }^{3}$ Berger and Bouwman find higher capital ratios enable all banks to improve their market share pre-crisis but only small and large banks maintain that improvement in market share after the crisis in the case of banking crises. But in the case of marketing crisis only small banks can benefit from having higher capital pre-

\footnotetext{
1 Berger and Bouwman categorize crises occurred in the US into two types; banking and marketing crises, and distinguish between them according to their sources. Banking crisis is that caused by banking system such as subprime crisis in 2008 , and market crisis is that caused by others such as dotcom crisis. In addition, capital structure refers to leverage or equity capital ratio and has been calculated here as the total equity capital scaled by gross total assets. ${ }^{2}$ Small banks refer to banks that have gross total assets (GTA) up to $\$ 1$ billion, medium banks that have gross total assets between $\$ 1$ to $\$ 3$ billions, and large banks that have GTA's value above $\$ 3$ billions).

${ }^{3}$ They calculate the percent change of market share as the difference between average level of market share during the crisis or over 8 quarter after it and the average level of market share over 8 quarter lag period and multiply by 100. For more detail see Berger and Bouwman (2009).
} 
crisis and also can maintain that improvement afterward. The results are shown in Table 2.5 .

Thirdly, Berger and Bouwman regress the change of return on equity (ROE) during and after a crisis on average level of capital ratio and the set of control variables to assess the effect of capital ratio on banks profitability. Berger and Bouwman find that higher capital shows no evidence of improvement in medium banks' profitability, while showing improvement in small and large banks during the banking crisis. However, only large banks can sustain the effect of higher capital upon profitability after a crisis. The results are shown in Table 2.6.

In addition, Berger and Bouwman find that improvement in market share and profitability due to higher capital ratios would lead to higher stock returns and abnormal stock returns for large banks if a banking crisis hits the economy. This, however, does not hold in a market crisis. Ironically, Berger and Bouwman find that in normal times higher capital benefits most small banks and that capital ratio is more important during crises, but not much before the crises.

Table 2.4: Estimation results of the effects of pre-crisis Equity Ratio on the ability to survive banking crises for Berger and Bouwman (2009)

\begin{tabular}{lcccccc}
\hline & \multicolumn{2}{c}{ Small Banks } & \multicolumn{2}{c}{ Medium Banks } & \multicolumn{2}{c}{ Large Banks } \\
\hline $\begin{array}{l}\text { Independent } \\
\text { Variables }\end{array}$ & SURV1 & SURV4 & SURV1 & SURV4 & SURV1 & SURV4 \\
$\begin{array}{l}\text { EQRAT } \\
\text { (Leverage) }\end{array}$ & $16.054^{* * *}$ & $12.759^{* * *}$ & $16.422^{* *}$ & $15.968^{* *}$ & $43.567^{* *}$ & 19.427 \\
& $(10.74)$ & $(9.96)$ & $(2.19)$ & $(2.33)$ & $(2.43)$ & $(1.43)$ \\
Ln(GTA) & $0.076^{*}$ & 0.061 & -0.028 & -0.432 & 0.117 & $0.413^{*}$ \\
& $(1.87)$ & $(1.63)$ & $(-0.07)$ & $(-1.13)$ & $(0.47)$ & $(1.70)$ \\
\hline
\end{tabular}




\begin{tabular}{lcccccc}
\hline Z-Score & $6.729^{* *}$ & $10.013^{* * *}$ & $20.021^{* *}$ & 11.345 & 2.182 & 17.192 \\
& $(2.49)$ & $(4.01)$ & $(2.04)$ & $(1.36)$ & $(0.16)$ & $(1.32)$ \\
D-BHC & $-0.667^{* * *}$ & $-0.713^{* * *}$ & 0.103 & -0.031 & $1.939^{\star * *}$ & $1.246^{\star *}$ \\
& $(-8.24)$ & $(-9.75)$ & $(0.26)$ & $(-0.08)$ & $(2.96)$ & $(2.10)$ \\
HHI & 0.298 & 0.349 & $4.818^{* *}$ & $4.480^{\star *}$ & 2.953 & 2.000 \\
& $(0.85)$ & $(1.11)$ & $(2.19)$ & $(2.23)$ & $(0.90)$ & $(0.70)$ \\
Inc-Growth & -1.374 & -1.445 & -6.845 & -5.144 & -6.251 & -2.156 \\
& $(-0.90)$ & $(-1.05)$ & $(-0.91)$ & $(-0.71)$ & $(-0.42)$ & $(-0.17)$ \\
Ln(POP) & $-0.216^{* * *}$ & $-0.228^{* * *}$ & 0.049 & 0.032 & 0.076 & 0.060 \\
& $(-11.88)$ & $(-13.74)$ & $(0.60)$ & $(0.41)$ & $(0.75)$ & $(0.64)$ \\
Constant & $2.854^{* * *}$ & $3.128^{* * *}$ & -1.158 & 4.786 & -5.688 & $-8.787^{* *}$ \\
& $(5.51)$ & $(6.66)$ & $(-0.19)$ & $(0.86)$ & $(-1.22)$ & $(-2.0)$ \\
Obs & 10364 & 10364 & 309 & 309 & 244 & 244 \\
\hline
\end{tabular}

Note: ${ }^{*} p<0.05 ;{ }^{* *} p<0.01 ;{ }^{* * *} p<0.001$

Standard errors in parenthesis

Dependent Variables: failed or survived the financial crisis

Table 2.5: Estimation results of the effects of pre-crisis Liquidity Ratio and Gross Total Assets on market Share during banking crises for Berger and Bouwman (2009)

\begin{tabular}{|c|c|c|c|c|c|c|c|c|c|c|c|c|}
\hline & \multicolumn{4}{|c|}{ Small Banks } & \multicolumn{4}{|c|}{ Medium Banks } & \multicolumn{4}{|c|}{ Large Banks } \\
\hline $\begin{array}{l}\text { Dep. } \\
\text { Vars. }\end{array}$ & $\% \mathrm{Ch}$ & e GTA & $\begin{array}{l}\text { \%Cl } \\
\text { L.C. }\end{array}$ & & $\% \mathrm{Ch}$ & e GTA & $\begin{array}{l}\text { \%C } \\
\text { L.C }\end{array}$ & & $\%$ & e GTA & $\begin{array}{l}\% C \\
\text { L.C }\end{array}$ & \\
\hline Ind. Vars & $\begin{array}{c}\text { Durin } \\
\mathrm{g}\end{array}$ & After & $\begin{array}{l}\text { Durin } \\
\mathrm{g}\end{array}$ & After & $\begin{array}{c}\text { Durin } \\
\mathrm{g}\end{array}$ & After & $\begin{array}{c}\text { Durin } \\
\mathrm{g}\end{array}$ & After & $\begin{array}{l}\text { Durin } \\
\mathrm{g}\end{array}$ & After & $\begin{array}{c}\text { Durin } \\
\mathrm{g}\end{array}$ & After \\
\hline $\begin{array}{l}\text { EQRAT } \\
\text { Leverage }\end{array}$ & $\begin{array}{c}1.118 \\
* * \star \\
(21.29 \\
)\end{array}$ & $\begin{array}{l}\underset{* * *}{1.019} \\
(6.71)\end{array}$ & $\begin{array}{c}4.496 \\
* * * \\
(22.01 \\
)\end{array}$ & $\begin{array}{c}7.428 \\
* * * \\
(10.55 \\
)\end{array}$ & $\begin{array}{l}0.495 \\
(1.48)\end{array}$ & $\begin{array}{c}-0.291 \\
(- \\
0.26)\end{array}$ & $\begin{array}{l}1.308 \\
\text { ** } \\
(2.24)\end{array}$ & $\begin{array}{r}4.174 \\
(0.89)\end{array}$ & $\begin{array}{l}\underset{* * *}{1.101} \\
(3.96)\end{array}$ & $\begin{array}{l}0.492 \\
(0.80)\end{array}$ & $\begin{array}{l}3.096 \\
* * \star \\
(3.62)\end{array}$ & $\begin{array}{l}{ }_{* \star \star}^{10.59} \\
(6.39)\end{array}$ \\
\hline $\operatorname{Ln}(\mathrm{GTA})$ & 0.004 & 0.039 & 0.029 & $0 . \overline{257}$ & $\begin{array}{c}- \\
0.122\end{array}$ & $\begin{array}{c}- \\
0.123\end{array}$ & $0 . \overline{-} 266$ & $\begin{array}{c}- \\
0.257\end{array}$ & 0.009 & $\begin{array}{c}- \\
0.015\end{array}$ & $\begin{array}{c}- \\
0.067\end{array}$ & $\begin{array}{c}- \\
0.094\end{array}$ \\
\hline
\end{tabular}




\begin{tabular}{|c|c|c|c|c|c|c|c|c|c|c|c|c|}
\hline & $\begin{array}{c}* * \\
(-2.2)\end{array}$ & $\begin{array}{c}{ }^{* * *} \\
(- \\
7.69)\end{array}$ & $\begin{array}{c}* * * \\
(- \\
4.28)\end{array}$ & $\begin{array}{c}{ }^{* * *} \\
(- \\
11.60)\end{array}$ & $\begin{array}{c}{ }^{\star * \star} \\
(- \\
5.24)\end{array}$ & $\begin{array}{c}0 \\
(- \\
1.58)\end{array}$ & $\begin{array}{c}\text { *** } \\
(- \\
3.93)\end{array}$ & $\begin{array}{c}0 \\
(- \\
0.98)\end{array}$ & $\begin{array}{c}0 \\
(- \\
1.08)\end{array}$ & $\begin{array}{c}0 \\
(- \\
0.49)\end{array}$ & $\begin{array}{c}{ }^{* * *} \\
(- \\
3.41)\end{array}$ & $\begin{array}{c}0 \\
(- \\
1.25)\end{array}$ \\
\hline Z-Score & $\begin{array}{c}- \\
0.468 \\
* * * \\
(- \\
6.25)\end{array}$ & $\begin{array}{l}0.260 \\
(1.09)\end{array}$ & $\begin{array}{c}- \\
0.640 \\
* * \\
(- \\
2.01)\end{array}$ & $\begin{array}{l}\underset{* * *}{6.112} \\
(4.72)\end{array}$ & $\begin{array}{l}0.152 \\
(0.52)\end{array}$ & $\begin{array}{c}2.024 \\
(1.5)\end{array}$ & $\begin{array}{l}0.147 \\
(0.20)\end{array}$ & $\begin{array}{c}-2.516 \\
(- \\
0.53)\end{array}$ & $\begin{array}{l}0.226 \\
(0.58)\end{array}$ & $\begin{array}{l}\underset{* *}{3.488} \\
(1.99)\end{array}$ & $\begin{array}{c}-0.944 \\
(- \\
0.87)\end{array}$ & $\begin{array}{c}-8.242 \\
(- \\
1.45)\end{array}$ \\
\hline D-BHC & $\begin{array}{c}-0.007 \\
* * \\
(- \\
8.24)\end{array}$ & $\begin{array}{l}0.011 \\
(1.40)\end{array}$ & $\begin{array}{c}0.040 \\
(2.90)\end{array}$ & $\begin{array}{l}0.217 \\
(5.69)\end{array}$ & $\begin{array}{l}\underset{*}{0.029} \\
(1.65)\end{array}$ & $\begin{array}{l}0.155 \\
* * \star \\
(2.80)\end{array}$ & $\begin{array}{l}0.100 \\
(1.54)\end{array}$ & $\begin{array}{l}0.376 \\
(1.65)\end{array}$ & $\begin{array}{c}-0.008 \\
(- \\
0.21)\end{array}$ & $\begin{array}{l}0.074 \\
(0.73)\end{array}$ & $\begin{array}{c}-0.054 \\
(- \\
0.38)\end{array}$ & $\begin{array}{c}-0.132 \\
(- \\
0.20)\end{array}$ \\
\hline $\mathrm{HHI}$ & $\begin{array}{l}\underset{* * *}{0.022} \\
(2.89)\end{array}$ & $\begin{array}{l}0.022 \\
(0.81)\end{array}$ & $\begin{array}{c}- \\
\underset{*}{0.063} \\
(-1.9)\end{array}$ & $\begin{array}{c}- \\
0.421 \\
* * * \\
2.71)\end{array}$ & $\begin{array}{l}0.077 \\
(1.13)\end{array}$ & $\begin{array}{c}-0.090 \\
(-0.3)\end{array}$ & $\begin{array}{l}0.232 \\
(1.22)\end{array}$ & $\begin{array}{l}2.017 \\
(1.63)\end{array}$ & $\begin{array}{l}0.038 \\
(0.31)\end{array}$ & $\begin{array}{c}-0.273 \\
(- \\
0.72)\end{array}$ & $\begin{array}{c}-0.145 \\
(- \\
0.54)\end{array}$ & $\begin{array}{c}-0.260 \\
(- \\
0.17)\end{array}$ \\
\hline $\begin{array}{l}\text { Inc- } \\
\text { Growth }\end{array}$ & $\begin{array}{c}0.81^{* *} \\
(14.97 \\
)\end{array}$ & $\begin{array}{c}1.875 \\
* \star \star \\
(12.24 \\
)\end{array}$ & $\begin{array}{l}1.305 \\
(6.19)\end{array}$ & $\begin{array}{l}2.100 \\
(2.99)\end{array}$ & $\begin{array}{l}0.596 \\
(1.51)\end{array}$ & $\begin{array}{l}0.075 \\
(0.07)\end{array}$ & $\begin{array}{l}0.996 \\
(0.84)\end{array}$ & $\begin{array}{c}2.44 \\
(0.54)\end{array}$ & $\begin{array}{c}-0.046 \\
(- \\
0.07)\end{array}$ & $\begin{array}{c}{ }^{3 .} \\
* * \\
(- \\
2.18)\end{array}$ & $\begin{array}{l}\underset{*}{4.755} \\
(1.81)\end{array}$ & $\begin{array}{r}5.847 \\
(0.87)\end{array}$ \\
\hline $\operatorname{Ln}(P O P)$ & $\begin{array}{c}0.01^{* *} \\
(12.23 \\
)\end{array}$ & $\begin{array}{c}0.024 \\
* * \star \\
(10.74 \\
)\end{array}$ & $\begin{array}{l}0.001 \\
(0.23)\end{array}$ & $\begin{array}{c}- \\
0.046 \\
* * * \\
(- \\
4.78)\end{array}$ & $\begin{array}{c}-0.001 \\
(- \\
0.16)\end{array}$ & $\begin{array}{l}0.015 \\
(1.32)\end{array}$ & $\begin{array}{l}0.003 \\
(0.22)\end{array}$ & $\begin{array}{c}-0.005 \\
(- \\
0.11)\end{array}$ & 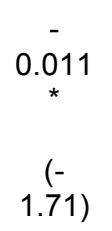 & $\begin{array}{c}-0.014 \\
(- \\
0.92)\end{array}$ & $\begin{array}{c}-0.022 \\
(- \\
1.29)\end{array}$ & $\begin{array}{c}- \\
0.090 \\
* \\
(- \\
1.75)\end{array}$ \\
\hline Constant & $\begin{array}{c}0 . \\
0.245 \\
* * * \\
(- \\
11.08)\end{array}$ & $\begin{array}{l}0.171 \\
* * * \\
(2.86)\end{array}$ & $\begin{array}{c}-0.097 \\
(- \\
1.09)\end{array}$ & $\begin{array}{c}3.603 \\
* * * \\
(13.21 \\
)\end{array}$ & $\begin{array}{l}1.625 \\
(4.94)\end{array}$ & $\begin{array}{l}1.606 \\
(1.45)\end{array}$ & $\begin{array}{l}\underset{* * *}{3.571} \\
(3.83)\end{array}$ & $\begin{array}{r}3.306 \\
(0.90)\end{array}$ & $\begin{array}{l}0.206 \\
(1.22)\end{array}$ & $\begin{array}{l}0.652 \\
(1.25)\end{array}$ & $\begin{array}{l}1.015 \\
(2.78)\end{array}$ & $\begin{array}{c}\underset{*}{2.612} \\
(1.76)\end{array}$ \\
\hline Obs & 16856 & 9070 & 16856 & 9070 & 639 & 233 & 639 & 233 & 446 & 209 & 446 & 209 \\
\hline Adj. $R^{2}$ & 0.17 & 0.06 & 0.07 & 0.05 & 0.07 & 0.01 & 0.03 & 0.00 & 0.05 & 0.02 & 0.06 & 0.08 \\
\hline
\end{tabular}

Note: ${ }^{*} p<0.05 ;{ }^{* *} p<0.01 ;{ }^{* * *} p<0.001$

Standard errors in parenthesis

Dependent Variables: the percent change in gross total assets and liquidity creation as measures of the percent change in market share for each bank 
Table 2.6: Estimation results of the effects of pre-crisis Capital Ratio on Profitability during banking crises for Berger and Bouwman (2009)

\begin{tabular}{|c|c|c|c|c|c|c|}
\hline & \multicolumn{2}{|c|}{ Small Banks } & \multicolumn{2}{|c|}{ Medium Banks } & \multicolumn{2}{|c|}{ Large Banks } \\
\hline $\begin{array}{l}\text { Independent } \\
\text { Variables }\end{array}$ & $\begin{array}{c}\text { Change } \\
\text { ROE } \\
\text { During }\end{array}$ & $\begin{array}{c}\text { Change } \\
\text { ROE After }\end{array}$ & $\begin{array}{c}\text { Change } \\
\text { ROE } \\
\text { During }\end{array}$ & $\begin{array}{c}\text { Change } \\
\text { ROE After }\end{array}$ & $\begin{array}{c}\text { Change } \\
\text { ROE } \\
\text { During }\end{array}$ & $\begin{array}{c}\text { Change } \\
\text { ROE After }\end{array}$ \\
\hline $\begin{array}{l}\text { EQRAT } \\
\text { (Leverage) }\end{array}$ & $\begin{array}{c}0.035^{* *} \\
(2.02)\end{array}$ & $\begin{array}{c}-0.157^{* * *} \\
(-4.84)\end{array}$ & $\begin{array}{l}0.015 \\
(0.14)\end{array}$ & $\begin{array}{c}-0.444^{* *} \\
(-1.99)\end{array}$ & $\begin{array}{l}0.172^{*} \\
(1.86)\end{array}$ & $\begin{array}{l}0.175^{*} \\
(1.67)\end{array}$ \\
\hline $\operatorname{Ln}(G T A)$ & $\begin{array}{l}-0.010^{* * *} \\
(-12.32)\end{array}$ & $\begin{array}{c}-0.007^{* * *} \\
(-6.12)\end{array}$ & $\begin{array}{l}0.008 \\
(0.76)\end{array}$ & $\begin{array}{l}0.029^{*} \\
(-1.73)\end{array}$ & $\begin{array}{l}-0.003 \\
(-0.69)\end{array}$ & $\begin{array}{l}0.004 \\
(0.53)\end{array}$ \\
\hline Z-Score & $\begin{array}{c}0.093^{* * *} \\
(3.28)\end{array}$ & $\begin{array}{c}-0.959^{* * *} \\
(-14.5)\end{array}$ & $\begin{array}{c}0.312^{* *} \\
(2.34)\end{array}$ & $\begin{array}{c}-1.459^{* * *} \\
(-5.13)\end{array}$ & $\begin{array}{l}0.218 \\
(1.20)\end{array}$ & $\begin{array}{c}-1.445^{\star * *} \\
(-3.75)\end{array}$ \\
\hline D-BHC & $\begin{array}{c}0.003^{* *} \\
(2.29)\end{array}$ & $\begin{array}{l}0.001 \\
(0.43)\end{array}$ & $\begin{array}{l}-0.004 \\
(-0.38)\end{array}$ & $\begin{array}{l}0.008 \\
(0.47)\end{array}$ & $\begin{array}{l}0.030^{*} \\
(1.69)\end{array}$ & $\begin{array}{l}0.041^{*} \\
(1.69)\end{array}$ \\
\hline $\mathrm{HHI}$ & $\begin{array}{l}-0.006 \\
(-1.61)\end{array}$ & $\begin{array}{c}-0.042^{* * *} \\
(-6.01)\end{array}$ & $\begin{array}{c}0.078^{* * *} \\
(2.77)\end{array}$ & $\begin{array}{l}-0.129^{*} \\
(-1.68)\end{array}$ & $\begin{array}{c}0.01 \\
(0.19)\end{array}$ & $\begin{array}{l}-0.063 \\
(-0.55)\end{array}$ \\
\hline Inc-Growth & $\begin{array}{c}-0.086^{* * *} \\
(-3.59)\end{array}$ & $\begin{array}{c}-0.097^{* * *} \\
(-2.71)\end{array}$ & $\begin{array}{l}-0.271 \\
(-1.22)\end{array}$ & $\begin{array}{c}-1.047^{* * *} \\
(-3.56)\end{array}$ & $\begin{array}{l}-0.364 \\
(-1.32)\end{array}$ & $\begin{array}{l}-0.302 \\
(-0.53)\end{array}$ \\
\hline $\operatorname{Ln}(P O P)$ & $\begin{array}{c}-0.005^{\star * *} \\
(-14.01)\end{array}$ & $\begin{array}{l}-0.001 \\
(-0.96)\end{array}$ & $\begin{array}{l}-0.004 \\
(-1.55)\end{array}$ & $\begin{array}{c}-0.010^{* * *} \\
(-2.71)\end{array}$ & $\begin{array}{l}0.001 \\
(0.31)\end{array}$ & $\begin{array}{l}-0.007 \\
(-1.65)\end{array}$ \\
\hline Constant & $\begin{array}{c}0.135^{\star * *} \\
(13.95)\end{array}$ & $\begin{array}{l}0.151^{* * *} \\
(10.79)\end{array}$ & $\begin{array}{l}-0.148 \\
(-0.98)\end{array}$ & $\begin{array}{l}-0.134 \\
(-0.65)\end{array}$ & $\begin{array}{l}-0.087 \\
(-1.10)\end{array}$ & $\begin{array}{l}0.053 \\
(0.37)\end{array}$ \\
\hline Obs & 16856 & 9070 & 639 & 233 & 446 & 209 \\
\hline Adj. $R^{2}$ & 0.08 & 0.06 & 0.05 & 0.18 & 0.04 & 0.05 \\
\hline
\end{tabular}

Note: ${ }^{*} p<0.05 ;{ }^{* *} p<0.01 ;{ }^{* * *} p<0.001$

Standard errors in parenthesis

Dependent Variables: the percent change in return on equity (ROE) during and after a crisis for each bank 
In another study conducted by Weib, Bostandizic and Neumann (2013), local and global measures for systemic risk were regressed as the dependent variables on a set of control variables associated with banks' characteristics including profitability, size, and leverage in addition to public safety-net guarantees and macroeconomic fundamentals for all countries in the sample and for each crisis covered in their study.

They followed the same methods of measuring the systemic risk as Schmidt and Stadtmuller (2006) and Acharya et al. (2010) by quantifying the change in Lower Tail Dependence (LTD) and Marginal Expected Shortfall (MES) for each bank respectively. ${ }^{1}$ Weib et al. ran regressions for different crises (Mexico, Asia, LTCM, Dotcom, 9/11, Subprime, and Lehman Brothers). Both global and local results are presented in Table 2.7.

Weib et al. find evidence in the extreme case (LTD) and testing locally that banks with higher total assets show a significant result as a one standard deviation increase in change of LTD would decrease a bank's probability of a joint crash with the local bank index by 4.1 percent in the subprime crisis and 5.2 percent in Lehman Brothers default. However these results did not hold when tested globally. Additionally, Weib et al. find leverage ratios to be insignificant both locally and globally, while the variable FUNDED (governments bail banks out) was significant at the one percent level globally and locally for subprime crisis but not for Lehman Brothers default as shown in Table 2.7 .

\footnotetext{
${ }^{1}$ The Lower Tail Dependence (LTD) for individual bank is estimated by the use of GARCH $(1,1)$ models to filter stock returns first before estimating LTD. The Marginal Expected Shortfall (MES) for individual bank is estimated by calculating the mean of the log of returns on stock market prices given that the local or global index experience an extreme downward movements. For more details on how to quantify systemic risk by these measures see Schmidt and Stadtmuller (2006) and Acharya et al (2010) respectively.
} 
Weib et al. find several firm characteristics did not show significant effects in crisis events before the subprime crisis.

By finding significant results associated only with profitability ratio and loan loss provision when shifting from local to global systemic risk using the LTD measure, Weib et al. concluded that firms' characteristics have a minor role in explaining extreme systemic risk globally. On the other hand, the explanatory power of regressions using the first measure of systemic risk (LTD) locally and globally was significantly lower than those using the second measure (MES) for moderate systemic risk.

Ultimately, Weib et al. reached the conclusion that the crises were driven by characteristics of the regulatory system such as deposit insurance schemes as it predicts the change in MES. For example, a positive relationship between regulatory capital and government funding and the systemic measure locally and globally and hold that significant relationship over three crises events.

Table 2.7: Estimation results of the analysis of two crises for Weib, Bostandizic and Neumann (2013)

\begin{tabular}{|c|c|c|c|c|c|c|c|c|}
\hline \multirow{3}{*}{ Ind. Vars. } & \multicolumn{2}{|c|}{$\begin{array}{l}\text { Extreme \& Local } \\
\text { Systemic Risk }\end{array}$} & \multicolumn{2}{|c|}{$\begin{array}{c}\text { Extreme \& Global } \\
\text { Systemic Risk }\end{array}$} & \multicolumn{2}{|c|}{$\begin{array}{l}\text { Moderate \& Local } \\
\text { Systemic Risk }\end{array}$} & \multicolumn{2}{|c|}{$\begin{array}{c}\text { Moderate \& Global } \\
\text { Systemic Risk }\end{array}$} \\
\hline & 1 & 2 & 3 & 4 & 5 & 6 & 7 & 8 \\
\hline & Subprime & $\begin{array}{l}\text { Lehman } \\
\text { Brothers }\end{array}$ & Subprime & $\begin{array}{l}\text { Lehman } \\
\text { Brothers }\end{array}$ & Subprime & $\begin{array}{l}\text { Lehman } \\
\text { Brothers }\end{array}$ & Subprime & $\begin{array}{l}\text { Lehman } \\
\text { Brothers }\end{array}$ \\
\hline \multirow[t]{2}{*}{ OPM } & 0.000 & 0.000 & $-0.001^{*}$ & 0.000 & 0.000 & $-0.000^{*}$ & $0.000^{* * *}$ & $0.000^{* *}$ \\
\hline & $(0.565)$ & $(0.905)$ & $(0.072)$ & $(0.831)$ & $(0.409)$ & $(0.070)$ & $(0.000)$ & $(0.022)$ \\
\hline \multirow[t]{2}{*}{ MTBV } & 0.002 & $-0.038^{*}$ & -0.014 & 0.012 & 0.001 & $0.007^{* * *}$ & -0.001 & $0.006^{* * *}$ \\
\hline & (0.905) & $(0.060)$ & $(0.328)$ & $(0.470)$ & $(0.554)$ & $(0.000)$ & $(0.429)$ & (0.001) \\
\hline LogTA & $-0.046^{* *}$ & $-0.059^{* *}$ & -0.003 & 0.029 & $0.005^{\star * *}$ & $0.020^{* * *}$ & -0.002 & $0.013^{* * *}$ \\
\hline
\end{tabular}




\begin{tabular}{|c|c|c|c|c|c|c|c|c|}
\hline & $(0.047)$ & $(0.040)$ & $(0.870)$ & $(0.230)$ & $(0.006)$ & $(0.000)$ & $(0.304)$ & $(0.000)$ \\
\hline \multirow[t]{2}{*}{ Leverage } & 0.000 & 0.001 & 0.001 & -0.001 & 0.000 & $-0.000^{* *}$ & 0.000 & 0.000 \\
\hline & $(0.637)$ & $(0.130)$ & $(0.183)$ & $(0.305)$ & $(0.190)$ & $(0.025)$ & $(0.307)$ & $(0.515)$ \\
\hline \multirow[t]{2}{*}{ LossProv } & 0.003 & -0.015 & -0.006 & $-0.023^{*}$ & 0.000 & $0.003^{* *}$ & 0.000 & $0.002^{* *}$ \\
\hline & $(0.672)$ & $(0.220)$ & $(0.330)$ & $(0.085)$ & $(0.626)$ & $(0.010)$ & $(0.720)$ & $(0.011)$ \\
\hline \multirow[t]{2}{*}{ LOGNII } & - & 0.011 & 0.011 & 0.005 & 0.002 & 0.000 & 0.003 & 0.002 \\
\hline & & $(0.514)$ & $(0.221)$ & $(0.711)$ & $(0.202)$ & $(0.932)$ & $(0.128)$ & $(0.176)$ \\
\hline \multirow[t]{2}{*}{ LOANS } & - & -0.001 & - & -0.001 & - & $0.000^{* *}$ & - & $0.000^{* * *}$ \\
\hline & & $(0.543)$ & & $(0.415)$ & & $(0.037)$ & & $(0.005)$ \\
\hline \multirow[t]{2}{*}{ INFL } & -0.003 & 0.001 & $-0.008^{*}$ & 0.004 & 0.001 & 0.000 & 0.000 & 0.000 \\
\hline & $(0.555)$ & $(0.717)$ & $(0.073)$ & $(0.281)$ & $(0.223)$ & $(0.300)$ & $(0.939)$ & $(0.465)$ \\
\hline \multirow[t]{2}{*}{ GDPGR } & 0.002 & 0.007 & 0.000 & $0.014^{*}$ & 0.000 & - & $-0.002^{* * *}$ & $0.003^{* * *}$ \\
\hline & $(0.848)$ & $(0.339)$ & $(0.989)$ & $(0.050)$ & $(0.625)$ & $(0.002)$ & $(0.000)$ & $(0.002)$ \\
\hline \multirow[t]{2}{*}{$\mathrm{HHI}$} & 0.007 & 0.131 & $0.356^{* * *}$ & $0.294^{*}$ & $-0.027^{* * *}$ & 0.000 & 0.002 & -0.003 \\
\hline & $(0.967)$ & $(0.536)$ & $(0.003)$ & $(0.064)$ & $(0.002)$ & $(0.980)$ & $(0.825)$ & $(0.801)$ \\
\hline \multirow[t]{2}{*}{ POLSTAB } & 0.045 & $-0.096^{\star *}$ & 0.010 & 0.005 & $0.006^{\star * *}$ & -0.005 & 0.001 & -0.002 \\
\hline & $(0.244)$ & $(0.034)$ & $(0.706)$ & $(0.894)$ & $(0.007)$ & $(0.225)$ & $(0.624)$ & $(0.629)$ \\
\hline \multirow[t]{2}{*}{ ROL } & -0.049 & 0.054 & $-0.061^{*}$ & 0.047 & -0.002 & 0.003 & $-0.006^{* * *}$ & $0.008^{* *}$ \\
\hline & $(0.272)$ & $(0.253)$ & $(0.059)$ & $(0.254)$ & $(0.389)$ & $(0.426)$ & $(0.008)$ & $(0.049)$ \\
\hline \multirow[t]{2}{*}{ FOREIGN } & -0.021 & 0.066 & 0.043 & $0.170^{* * *}$ & 0.001 & 0.003 & 0.000 & $0.016^{* * *}$ \\
\hline & $(0.637)$ & $(0.156)$ & $(0.153)$ & $(0.000)$ & $(0.766)$ & $(0.342)$ & $(0.898)$ & $(0.000)$ \\
\hline \multirow[t]{2}{*}{ COINS } & 0.020 & -0.051 & -0.025 & 0.003 & -0.002 & -0.004 & $-0.005^{*}$ & 0.008 \\
\hline & $(0.748)$ & $(0.444)$ & $(0.499)$ & $(0.959)$ & $(0.540)$ & $(0.578)$ & $(0.085)$ & $(0.143)$ \\
\hline \multirow[t]{2}{*}{ PMT } & 0.068 & 0.007 & 0.038 & -0.003 & 0.000 & $0.015^{* * *}$ & $-0.005^{\star *}$ & $0.017^{* * *}$ \\
\hline & $(0.125)$ & $(0.870)$ & $(0.145)$ & $(0.925)$ & $(0.932)$ & $(0.000)$ & $(0.013)$ & $(0.000)$ \\
\hline \multirow[t]{2}{*}{ FUNDED } & $-0.101^{\star * *}$ & $0 .-$ & $-0.071^{\star *}$ & -0.063 & $0.010^{* * *}$ & $0.015^{\star * *}$ & 0.002 & $0.005^{*}$ \\
\hline & $(0.010)$ & $(0.000)$ & $(0.014)$ & $(0.137)$ & $(0.000)$ & $(0.000)$ & $(0.407)$ & $(0.079)$ \\
\hline CRI & 0.003 & 0.008 & -0.008 & -0.014 & $0.002^{* *}$ & $0.002^{* *}$ & -0.001 & 0.001 \\
\hline
\end{tabular}




\begin{tabular}{ccccccccc}
\hline & $(0.803)$ & $(0.579)$ & $(0.332)$ & $(0.186)$ & $(0.042)$ & $(0.031)$ & $(0.388)$ & $(0.175)$ \\
GOB & -0.025 & 0.025 & -0.043 & $-0.189^{*}$ & 0.004 & $-0.022^{* *}$ & $0.012^{* *}$ & - \\
& $(0.848)$ & $(0.801)$ & $(0.584)$ & $(0.051)$ & $(0.629)$ & $(0.017)$ & $(0.039)$ & $0.033^{* * *}$ \\
& & & & & & & & $(0.001)$ \\
MHI & -0.001 & -0.001 & $-0.015^{* *}$ & $0.021^{* *}$ & 0.000 & -0.002 & -0.001 & $0.002^{* *}$ \\
& $(0.939)$ & $(0.937)$ & $(0.040)$ & $(0.045)$ & $(0.483)$ & $(0.124)$ & $(0.130)$ & $(0.010)$ \\
IOSA & -0.006 & 0.003 & 0.013 & 0.009 & 0.002 & 0.000 & 0.001 & 0.001 \\
& $(0.800)$ & $(0.890)$ & $(0.293)$ & $(0.622)$ & $(0.164)$ & $(0.895)$ & $(0.174)$ & $(0.454)$ \\
OSP & -0.010 & 0.002 & 0.004 & $0.017^{* *}$ & 0.000 & $0.003^{* * *}$ & $-0.001^{* * *}$ & $0.002^{* * *}$ \\
& $(0.232)$ & $(0.862)$ & $(0.531)$ & $(0.028)$ & $(0.329)$ & $(0.000)$ & $(0.005)$ & $(0.002)$ \\
ADRI & 0.024 & -0.010 & $0.041^{* * *}$ & 0.008 & $0.002^{*}$ & -0.001 & $0.003^{* *}$ & -0.001 \\
& $(0.242)$ & $(0.595)$ & $(0.004)$ & $(0.695)$ & $(0.078)$ & $(0.751)$ & $(0.017)$ & $(0.585)$ \\
\hline Obs & 854 & 888 & 854 & 888 & 854 & 888 & 854 & 888 \\
$R^{2}$ & 0.025 & 0.091 & 0.051 & 0.126 & 0.155 & 0.266 & 0.195 & 0.269 \\
Adj. $R^{2}$ & 0.001 & 0.068 & 0.027 & 0.104 & 0.133 & 0.247 & 0.175 & 0.251 \\
\hline Note: ${ }^{*} \mathrm{p}<0.05 ;{ }^{* *} p<0.01 ;{ }^{* * *} \mathrm{p}<0.001$ & & & & & &
\end{tabular}

Standard errors in parenthesis

Dependent Variables: the change in Lower Tail Dependence (LTD) and Marginal Expected Shortfall (MES) for each bank

Blundell-Wignall and Roulet (2013) analyze variables causing firms' defaults striving to offer beneficial solutions for regulators. Blundell-Wignall and Roulet investigate the impact of both macro- and micro-variables upon firms' defaults by quantifying the distance to default by measuring the number of standard deviations away from the default point. They define the default point as the market-valued of assets equals or lower than the total book-valued of debt. Blundell-Wignall and Roulet use the Black-Scholes model to measure the market-valued of assets and throughout the data for 94 publically traded banks and dealers in the US and EU had market 
capitalization above $\$ 5$ billion from 2004 to $2011 .{ }^{1}$ Panel regression was used to assess the changes in the outcome across all banks over the specified period. Simple leverage and Tier I leverage ratios were used as control variables. ${ }^{2}$

Blundell-Wignall and Roulet find simple leverage to be significant relative to Tier I leverage ratio as shown in Table 2.8 and Table 2.9 according to univariate and multivariate models respectively. First, the univariate model indicated that regular leverage is significant at the one percent level in predicting the distance to default compared to the Tier I leverage ratio. In addition, a group of other variables showed significant relationships with the outcome such as firm size, trading assets, the gross market value of derivatives, cross-border revenue and beta.

Conversely, the multivariate model showed that regular or simple leverage ratios were significant over three subsamples particularly in the 'all banks' sample which was significant at the one percent level. Tier I leverage was not significant in the multivariate model. Firm size was significant at the one percent level when Tier I was used, and at the five percent level when simple leverage was used. However, firm size was not significant for the third subsample (other large banks).

\footnotetext{
${ }^{1}$ For more information about Black-Scholes model see Black and Scholes (1973) and Merton (1973).

${ }^{2}$ Simple leverage ratio calculated as \{total assets / (total equity - goodwill and other intangible assets)\}, and Tier I leverage ratio calculated as \{Tier I capital / total risk-weighted assets\}. For more details see Adrian Blundell-Wignall and Caroline Roulet (2013).
} 
Table 2.8: Estimation results of the univariate model for Blundell-Wignall and Roulet (2013)

\begin{tabular}{|c|c|c|c|c|c|c|c|c|c|c|c|c|c|}
\hline Cons. & $\begin{array}{c}\underset{*}{6.87^{* *}} \\
(27.1 \\
5)\end{array}$ & $\begin{array}{c}\underset{*}{6.51^{* *}} \\
\\
(26.6 \\
6)\end{array}$ & 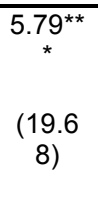 & 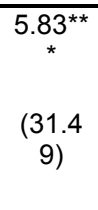 & 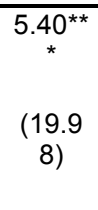 & $\begin{array}{c}\underset{*}{6.34^{* *}} \\
\\
(17.7 \\
5)\end{array}$ & $\begin{array}{c}\underset{*}{4.16^{* *}} \\
3.24) \\
(-\end{array}$ & $\begin{array}{l}\underset{*}{4.84^{* *}} \\
(2.47)\end{array}$ & $\begin{array}{c}\underset{* 58^{* \star}}{ } \\
(25.9 \\
3)\end{array}$ & $\begin{array}{l}\underset{*}{7.32^{* \star}} \\
(4.14)\end{array}$ & 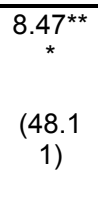 & $\begin{array}{l}5.16^{\star \star \star} \\
(45.27)\end{array}$ & 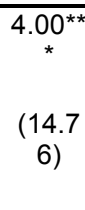 \\
\hline $\begin{array}{c}\text { Bank } \\
\text { Size } \\
\text { TA/SysT } \\
\text { A }\end{array}$ & $\begin{array}{c}\bar{c}^{-} \\
7.83^{* *} \\
(- \\
3.83)\end{array}$ & - & - & - & - & - & - & - & - & - & - & - & - \\
\hline $\begin{array}{l}\text { Leverage } \\
\text { TA/(TE- } \\
\text { GW) }\end{array}$ & - & $\begin{array}{c}\underset{*}{0.02^{* *}} \\
(- \\
2.33)\end{array}$ & - & - & - & - & - & - & - & - & - & - & - \\
\hline $\begin{array}{c}\text { TILev } \\
\text { Tierl/RW } \\
\text { A }\end{array}$ & - & - & $\begin{array}{l}2.97 \\
(0.87)\end{array}$ & - & - & - & - & - & - & - & - & - & - \\
\hline IBA/TA & - & - & - & $\begin{array}{r}1.30 \\
(0.80)\end{array}$ & - & - & - & - & - & - & - & - & - \\
\hline $\mathrm{TD} / \mathrm{TA}$ & - & - & - & - & $\begin{array}{l}2.56^{* *} \\
(2.28)\end{array}$ & - & - & - & - & - & - & - & - \\
\hline WFD/TL & - & - & - & - & - & $\begin{array}{c}-1.08 \\
(- \\
1.16)\end{array}$ & - & - & - & - & - & - & - \\
\hline GMV/TA & - & - & - & - & - & - & $\begin{array}{c}\underset{4.16^{* *}}{*} \\
3.24)\end{array}$ & - & - & - & - & - & - \\
\hline No. & - & - & - & - & - & - & - & $\begin{array}{c}0.01 \\
(0.58)\end{array}$ & - & - & - & - & - \\
\hline $\mathrm{XB} / \mathrm{TR}$ & - & - & - & - & - & - & - & - & $\begin{array}{l}1.53^{* *} \\
(2.00)\end{array}$ & - & - & - & - \\
\hline Exp/Emp & - & - & - & - & - & - & - & - & - & $\begin{array}{c}-0.32 \\
(- \\
0.79)\end{array}$ & - & - & - \\
\hline Beta & - & - & - & - & - & - & - & - & - & - & $\underset{*}{3.08^{* *}}$ & - & - \\
\hline
\end{tabular}




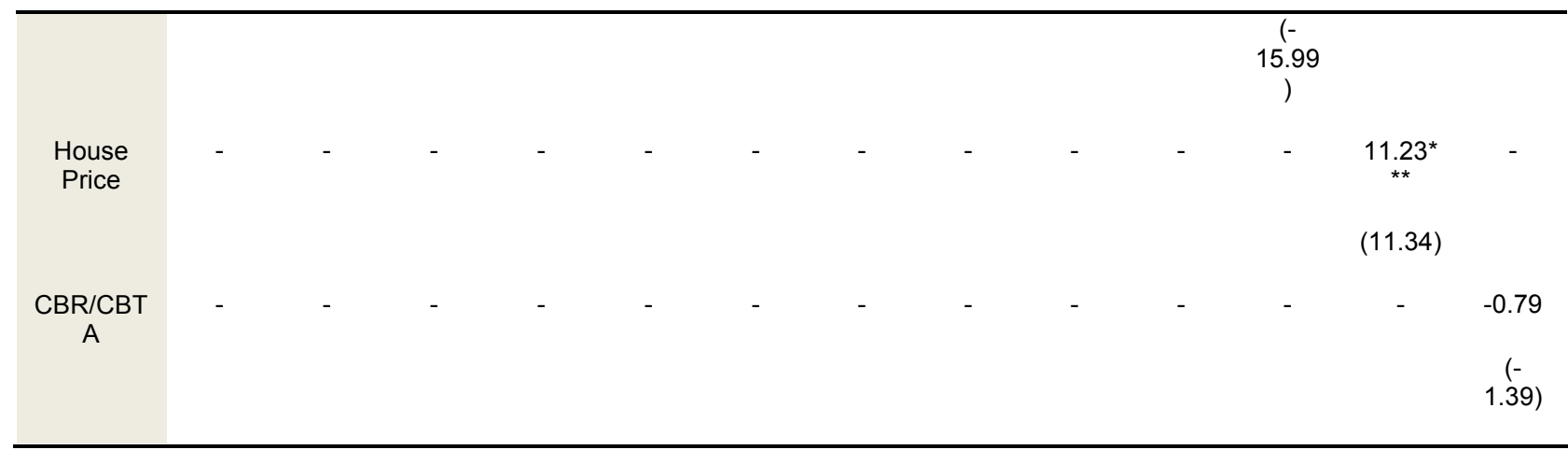

Note: ${ }^{*} p<0.05 ;{ }^{* *} p<0.01 ;{ }^{* *} p<0.001$

Standard errors in parenthesis

Dependent Variable: the distance to default by measuring how many standard deviations away from the default point

Table 2.9: Estimation results of the multivariate model for Blundell-Wignall and Roulet (2013)

\begin{tabular}{ccccccc}
\hline & \multicolumn{2}{c}{ All Banks } & \multicolumn{2}{c}{ GSIFIs } & \multicolumn{2}{c}{ Other Large Banks } \\
\hline Bank Size & $-4.02^{* *}$ & $-4.90^{* * *}$ & $-3.97^{* *}$ & $-5.06^{* * *}$ & -4.94 & -3.59 \\
TA/SysTA & $(-1.91)$ & $(02.60)$ & $(-2.14)$ & $(-4.51)$ & $(-0.94)$ & $(-0.63)$ \\
Leverage & $-0.03^{* * *}$ & - & $-0.02^{* * *}$ & - & $-0.04^{* *}$ & - \\
TA/(TE-GW) & $(-3.01)$ & & $(-3.34)$ & & $(-2.06)$ & \\
\hline TeirlLeverage & - & 0.95 & - & $4.97^{*}$ & - & -2.05 \\
Tierl/RWA & & $(0.31)$ & & $(1.76)$ & & $(-0.55)$ \\
IntBanA/TA & 0.53 & 0.16 & -0.36 & -0.56 & 1.66 & 0.89 \\
& $(0.40)$ & $(0.11)$ & $(-0.24)$ & $(-0.36)$ & $(0.79)$ & $(0.35)$ \\
TD/TA & $2.24^{* *}$ & 1.39 & $3.79^{* * *}$ & $2.56^{* *}$ & 0.17 & 0.01 \\
& $(2.24)$ & $(1.27)$ & $(3.38)$ & $(2.32)$ & $(0.11)$ & $(0.00)$ \\
\hline WFD/TL & $-2.67^{* * *}$ & $-3.51^{* * *}$ & -2.36 & $-3.56^{* *}$ & -1.70 & -2.47 \\
& $(-2.67)$ & $(-3.15)$ & $(-1.59)$ & $(-2.13)$ & $(-1.16)$ & $(-1.50)$ \\
& $-2.87^{* * *}$ & $-4.03^{* * *}$ & $-1.67^{* * *}$ & $-2.16^{* * *}$ & -2.76 & -3.30 \\
\hline GMV/TA & $(-2.62)$ & $(-3.68)$ & $(-3.07)$ & $(-7.06)$ & $(-1.20)$ & $(-1.44)$ \\
& 0.01 & 0.01 & 0.01 & 0.01 & 0.14 & 0.07 \\
\hline No. & $(0.43)$ & $(0.43)$ & $(0.59)$ & $(1.41)$ & $(1.40)$ & $(0.65)$ \\
\hline & & & & & & \\
\hline
\end{tabular}




\begin{tabular}{ccccccc}
\hline XB/TR & 0.61 & 0.82 & $3.24^{* * *}$ & $2.76^{* * *}$ & $-1.69^{*}$ & -1.59 \\
& $(0.92)$ & $(1.20)$ & $(4.77)$ & $(3.84)$ & $(-1.75)$ & $(-1.46)$ \\
Exp/Emp & 0.10 & -0.33 & 0.04 & -0.30 & 0.46 & 0.07 \\
& $(0.26)$ & $(-0.82)$ & $(0.07)$ & $(-0.66)$ & $(0.83)$ & $(0.11)$ \\
Beta & $-2.40^{* * *}$ & $-2.42^{* * *}$ & $-2.50^{* * *}$ & $-2.54^{* * *}$ & $-2.28^{* * *}$ & $-2.32^{* * *}$ \\
& $(-16.31)$ & $(-16.37)$ & $(-15.14)$ & $(-14.79)$ & $(-11.86)$ & $(-11.73)$ \\
House Price & $8.89^{* * *}$ & $10.14^{* * *}$ & $9.44^{* * *}$ & $10.78^{* * *}$ & $10.34^{* * *}$ & $11.61^{* * *}$ \\
& $(9.59)$ & $(10.45)$ & $(3.06)$ & $(3.46)$ & $(7.74)$ & $(7.91)$ \\
CBR/CBTA & -1.03 & -0.83 & -0.92 & -0.75 & -0.72 & -1.06 \\
& $(-1.53)$ & $(-1.22)$ & $(-1.20)$ & $(-1.14)$ & $(-0.65)$ & $(-0.85)$ \\
Constant & $8.19^{* * *}$ & $10.17^{* * *}$ & $6.53^{* * *}$ & $7.85^{* * *}$ & 1.32 & 5.86 \\
& $(3.36)$ & $(4.05)$ & $(2.81)$ & $(3.62)$ & $(0.25)$ & $(1.01)$ \\
\hline Obs & 467 & 418 & 196 & 180 & 271 & 238 \\
$R^{*}$ & 0.84 & 0.85 & 0.88 & 0.89 & 0.83 & 0.84 \\
\hline
\end{tabular}

Note: ${ }^{*} p<0.05 ;{ }^{* *} p<0.01 ;{ }^{* * *} p<0.001$

Standard errors in parenthesis

Dependent Variable: the distance to default by measuring how many standard deviations away from the default point

Adrian and Brunnermeier (2011) introduce their systemic measure, Conditional Value-at-Risk (CoVaR) in an attempt to predict future systemic risk by quantifying each firm's contribution to future systemic risk based upon a set of current fundamental variables such as size, liquidity (mismatch between assets and liabilities), and leverage ratio (capital structure).

Adrian and Brunnermeier collected market equity and quarterly balance sheet data for 1226 publically traded financial firms for the period 1986Q1-2010Q4 and categorized these firms into four groups including commercial banks, security broker- 
dealers, insurance, and real estate firms. Adrian and Brunnermeier conducted their study over quarterly, one year, and two years lagged variables related to firms' characteristics and used Quantile regression to estimate the systemic measure 'CoVar.'1

Adrian and Brunnermeier (2011) built the dependent variable on weekly changes in the market value of the total assets. ${ }^{2}$ Their measure $(\mathrm{VaR}=\mathrm{CoVaR})$ is a function of a selected set of state variables in order to capture the time-variation in asset returns (the change in market-valued assets). In addition, Adrian and Brunnermeier defined " $\triangle \mathrm{CoVaR}$ " as the difference between two CoVar values in order to quantify the financial firm's marginal contribution to systemic risk. The first value is when a firm is under distress and the second value when normal conditions existed. ${ }^{3}$ Their results are shown in Table 2.10 below. The table shows that firms with higher leverage, larger size, and more maturity mismatch ratios are expected to participate more to the systemic risk in one quarter, one year, and two years later at the significant levels of 1 and 5 percent. For example, an increase in leverage ratio over a two years period by one unit (i.e. from 15 to 16$)$, the model finds the systemic risk contribution will increase by 6.76 basis points of quarterly asset returns at the level of 5 percent and that translates into $\$ 67.6$ billions of systemic risk contribution if the firm's market-valued asset equals $\$ 1$ trillion.

\footnotetext{
${ }^{1}$ By running 1-\% Quantile regressions of financial institutions returns on one-week lag period of the selected state variables and compute the predicted value of the regression, they obtained $V_{a R}{ }^{i}$ to be included in the regression to predict $\triangle \mathrm{CoVaR}^{i}$ Where i refers to bank.

${ }^{2}$ The change in market-valued assets $(\Delta A)=\left[A_{t}-A_{t-1}\right] / A_{t-1}$. Where $A_{t-1}$ equal to the multiplication of market-valued equity and the ratio of leverage at previous period, and $A_{t}$ equal to the multiplication of market-valued equity and the ratio of leverage at current period. $\triangle A=$ $\left[\mathrm{MVE}_{\mathrm{t}}{ }^{*} \mathrm{LEV}_{\mathrm{t}}-\mathrm{MVE}_{\mathrm{t}-1}{ }^{*} \mathrm{LEV}_{\mathrm{t}-1}\right] /\left[\mathrm{MVE}_{\mathrm{t}-1}{ }^{*} \mathrm{LEV}_{\mathrm{t}-1}\right]$. For more details see Adrian and Brunnermeier (2011).

${ }^{3} \Delta \mathrm{CoVaR}^{\mathrm{i}}$ is the difference between $1 \%-\mathrm{CoVaR}^{\mathrm{i}}$ and the $50 \%-\mathrm{CoVaR}^{\mathrm{i}}$, where the $\mathrm{q}-\%-\mathrm{CoVaR}^{\mathrm{i}}$ is the predicted value from a q-\%Quantile regression of the financial system asset retunes on the institution asset retunes and on the lagged state variables.
} 
In addition, Adrian and Brunnermeier show that capital requirement (Tier I capital requirement) should not be the same for small and large banks given that both have the same leverage ratio. For example, Tier I capital requirement of 7 percent for small banks means 1:14 maximum leverage ratio. Therefore, in order to have the same $\Delta \mathrm{CoVaR}$ per unit of capital, larger banks need to reduce their maximum leverage ratio to 1:10 or equivalently increase their capital requirement to 10 percent. However, the table shows little difference in $R^{2}$ values for each level of significance, the two years lag period shows the highest predictive power relative to the other lags.

Table 2.10: Estimation results for Adrian and Brunnermeier (2011)

\begin{tabular}{|c|c|c|c|c|c|c|}
\hline & \multicolumn{3}{|c|}{$5 \% \Delta$ CoVaR $^{i}$} & \multicolumn{3}{|c|}{$1 \% \Delta$ CoVaR $^{i}$} \\
\hline \multirow{2}{*}{$\begin{array}{l}\text { Lagged } \\
\text { Variables }\end{array}$} & 1 & 2 & 3 & 4 & 5 & 6 \\
\hline & 2 Years & 1 Year & 1 Quarter & 2 Years & 1 Year & 1 Quarter \\
\hline \multirow[t]{2}{*}{ VaR } & -0.019 & -0.012 & -0.007 & -0.019 & -0.014 & -0.010 \\
\hline & $(0.001)$ & $(0.001)$ & $(0.002)$ & $(0.001)$ & $(0.001)$ & $(0.001)$ \\
\hline \multirow{2}{*}{$\begin{array}{c}\text { Log BV } \\
\text { Equity }\end{array}$} & -285.129 & -279.689 & -277.861 & -339.067 & -334.523 & -333.238 \\
\hline & $(5.553)$ & (5.195) & $(5.105)$ & $(10.067)$ & $(9.472)$ & $(9.372)$ \\
\hline \multirow[t]{2}{*}{ Beta } & -72.821 & -92.945 & -99.459 & -115.287 & -142.982 & -152.082 \\
\hline & (6.981) & $(6.372)$ & $(6.220)$ & $(13.104)$ & $(12.117)$ & $(11.837)$ \\
\hline \multirow{2}{*}{$\begin{array}{l}\text { Maturity } \\
\text { Mismatch }\end{array}$} & -13.819 & -12.059 & -11.650 & -46.644 & -43.797 & -43.048 \\
\hline & (7.398) & (7.166) & $(6.866)$ & $(14.057)$ & (13.901) & $(13.386)$ \\
\hline \multirow[t]{2}{*}{ MV/BV } & -18.480 & -17.571 & -16.672 & -22.827 & -21.457 & -20.084 \\
\hline & (3.490) & $(3.400)$ & (2.988) & $(5.543)$ & $(5.415)$ & $(4.856)$ \\
\hline \multirow[t]{2}{*}{ Volatility } & -11.787 & -7.516 & -6.760 & -5.779 & -1.747 & -4.016 \\
\hline & $(2.701)$ & $(2.686)$ & $(3.550)$ & $(5.523)$ & $(5.512)$ & $(7.386)$ \\
\hline Leverage & -6.765 & -7.220 & -7.229 & -6.924 & -6.836 & -7.187 \\
\hline
\end{tabular}




\begin{tabular}{|c|c|c|c|c|c|c|}
\hline & $(1.965)$ & $(1.866)$ & $(1.811)$ & (3.472) & $(3.256)$ & $(3.105)$ \\
\hline \multirow[t]{2}{*}{ Foreign FE } & 347.227 & 328.697 & 324.499 & 334.195 & 316.836 & 307.916 \\
\hline & $(57.440)$ & $(54.077)$ & $(52.155)$ & $(87.040)$ & $(81.886)$ & $(78.677)$ \\
\hline \multirow{2}{*}{$\begin{array}{c}\text { Insurance } \\
\text { FE }\end{array}$} & 91.849 & 91.790 & 95.932 & 25.479 & 36.303 & 48.558 \\
\hline & $(25.307)$ & $(24.119)$ & $(23.583)$ & $(45.142)$ & $(42.953)$ & $(41.763)$ \\
\hline \multirow{2}{*}{$\begin{array}{c}\text { Real Estate } \\
\text { FE }\end{array}$} & -68.005 & -59.171 & -56.493 & -318.607 & -293.028 & -285.247 \\
\hline & (32.997) & (31.808) & $(31.031)$ & $(64.465)$ & $(62.064)$ & $(60.481)$ \\
\hline \multirow{2}{*}{$\begin{array}{c}\text { Broker } \\
\text { Dealer FE }\end{array}$} & -343.445 & -322.611 & -304.797 & -438.256 & -416.258 & -398.936 \\
\hline & $(36.363)$ & (35.215) & $(34.418)$ & $(64.008)$ & $(61.757)$ & (59.679) \\
\hline \multirow[t]{2}{*}{ Others FE } & -52.677 & -35.127 & -20.558 & 10.638 & 32.362 & 48.961 \\
\hline & $(35.654)$ & (33.646) & $(32.380)$ & $(66.097)$ & $(63.482)$ & $(61.396)$ \\
\hline \multirow[t]{2}{*}{ Constant } & 4419.804 & 4577.975 & 4621.168 & 4922.344 & 5217.287 & 5305.055 \\
\hline & (126.317) & $(112.639)$ & (112.157) & $(230.424)$ & $(205.215)$ & (204.945) \\
\hline Obs. & 49351 & 54127 & 57750 & 49351 & 54127 & 57750 \\
\hline $\begin{array}{c}\text { Adjusted } \\
\mathrm{R}^{2}\end{array}$ & $43.63 \%$ & $43.05 \%$ & $42.59 \%$ & $25.78 \%$ & $25.48 \%$ & $25.01 \%$ \\
\hline
\end{tabular}

Note: Standard errors in parenthesis

Dependent Variable: weekly changes in market value of the total assets

Acharya, Pedersen, Philippon, and Richardson (2010) introduced another study examining an ex-ante measure for systemic risk called the systemic expected shortfall (SES). This study addresses the question pertaining to which institutions contribute most to systemic risk by examining cross-sectional data for financial firms. ${ }^{1}$ In their study, Acharya et al. consider financial reports and stock market data. According to financial reports, Acharya et al. include standard approximation of financial leverage

\footnotetext{
${ }^{1}$ SES is calculated based on the expected amount of capital a bank is short of given that the financial system is short of capital as well. In other words, the expected shortfall is the average of returns in periods when the firm's loss exceeds its value-at-risk limits.
} 
and a measure of firm size by taking a natural log of book value of assets for each firm on a quarterly bases from CRSP-Compustat dataset ${ }^{1}$. Stock market returns have been used as a dependent variable during the crisis period (July, 2007 until December, 2008), and as an independent variable as a source of calculating the marginal expected shortfall variable (MES) ${ }^{2}$. Acharya et al. used data that consisted of 102 financial firms categorized as banks, dealers, insurance, others and real estate firms. Their results according to OLS regression and Tobit analysis presented in Tables 2.11 and 2.12 respectively which indicate that the firms with the highest ratios of leverage and MES contributed the most to systemic risk.

However, Acharya et al.s evidence also suggests that MES and leverage were the most significant indicators predicting how much a firm was contributing to systemic risk. Acharya et al. also find that other standard measures of firm-risk such as value-atrisk, volatility and expected loss had no explanatory power, while the covariance of a firm's stock returns with the market scaled by the variance of market returns had only modest explanatory power.

Acharya et al. propose tax policy as a function of the ratios of leverage and MES in an attempt to put some regulations in place. This type of tax would contribute to the reduction of making risky decisions by managers regarding daily investments, and ultimately minimize the probability of firms' defaults on their debts and the possibility of ex-post bailout and spillover effects.

\footnotetext{
${ }^{1}$ The standard approximation of financial leverage has been calculated by the use of quasimarket value of assets instead of book value. The formula that they used is as the following: $\mathrm{LVG}^{\mathrm{MV}}=$ (quasi-market value of assets / market value of equity), similarly $\mathrm{LVG}^{\mathrm{MV}}=$ ([book value of assets - book value of equity + market value of equity] / [market value of equity])

${ }^{2}$ The marginal expected shortfall calculated as of the average of equity return or loss for a firm during the $5 \%$ worst days for the market returns in any given year.
} 
Table 2.11: Estimation results of OLS regressions for Acharya et al. (2010)

\begin{tabular}{|c|c|c|c|c|c|c|c|c|}
\hline & & & & Moc & & & & \\
\hline $\begin{array}{l}\text { Independent } \\
\text { Variables }\end{array}$ & (1) & (2) & (3) & (4) & (5) & (6) & (7) & (8) \\
\hline MES & & & $-0.21^{* * *}$ & & & $-0.15^{\star *}$ & & $-0.17^{* *}$ \\
\hline & & & $(-2.90)$ & & & $(-2.25)$ & & $(-2.08)$ \\
\hline Leverage & & & & & $-0.04^{* * *}$ & $-0.04^{* * *}$ & & $-0.03^{* *}$ \\
\hline & & & & & $(-5.73)$ & $(-5.43)$ & & $(-2.29)$ \\
\hline ES & -0.05 & & & & & & & \\
\hline & $(-1.14)$ & & & & & & & \\
\hline Volatility & & 0.04 & & & & & & -0.07 \\
\hline & & (0.07) & & & & & & $(-0.12)$ \\
\hline Beta & & & & $-0.29^{* *}$ & & & & \\
\hline & & & & $(-2.24)$ & & & & \\
\hline Log Assets & & & & & & & $-0.09 * * *$ & $-0.05^{\star}$ \\
\hline & & & & & & & $(-4.86)$ & $(-1.69)$ \\
\hline Industry & $-0.32^{* * *}$ & $-0.44^{* * *}$ & -0.13 & -0.18 & $-0.18^{* *}$ & 0.02 & $0.61^{* * *}$ & 0.5 \\
\hline 5 & $(-2.71)$ & $(-3.81)$ & $(-1.09)$ & $(-1.42)$ & $(-2.5)$ & $(0.20)$ & $(2.75)$ & (1.61) \\
\hline Constant & & & & & & & & \\
\hline Other & -0.04 & -0.09 & 0.01 & 0.012 & $-0.2^{* *}$ & -0.12 & $-0.25^{\star * *}$ & -0.15 \\
\hline & $(-0.33)$ & $(-0.91)$ & $(0.14)$ & $(0.12)$ & $(-2.44)$ & $(-1.35)$ & $(-2.87)$ & $(-1.61)$ \\
\hline Insurance & 0.43 & -0.68 & -3.63 & -2.95 & -8.86 & -10.17 & -0.09 & -0.11 \\
\hline & $(0.05)$ & $(-0.08)$ & $(-0.45)$ & $(-0.36)$ & $(-1.19)$ & $(-1.39)$ & $(-1.13)$ & $(-1.55)$ \\
\hline Broker & -0.09 & -0.16 & 0.11 & 0.06 & -0.02 & 0.16 & -0.17 & 0.14 \\
\hline & $(-0.65)$ & $(-1.2)$ & $(0.71)$ & $(0.36)$ & $(-0.18)$ & (1.19) & $(-1.56)$ & $(1.02)$ \\
\hline No. Obs & 102 & 102 & 102 & 102 & 101 & 101 & 101 & 101 \\
\hline Pseudo $\mathrm{R}^{2}$ & $0 \%$ & $-1.36 \%$ & $6.72 \%$ & $3.62 \%$ & $24.27 \%$ & $27.34 \%$ & $18.46 \%$ & $28.02 \%$ \\
\hline
\end{tabular}


Dependent Variable: Stock market returns during the crisis period (July, 2007 until December, 2008)

Table 2.12: Estimation results of Tobit analysis for Acharya et al. (2010)

\begin{tabular}{|c|c|c|c|c|c|c|c|c|}
\hline & \multicolumn{8}{|c|}{ Models } \\
\hline $\begin{array}{l}\text { Independent } \\
\text { Variables }\end{array}$ & (1) & (2) & (3) & (4) & (5) & (6) & (7) & (8) \\
\hline MES & & & $\begin{array}{l}-0.23^{* * *} \\
(-2.85)\end{array}$ & & & $\begin{array}{c}- \\
0.001^{* *} \\
(-2.03)\end{array}$ & & $\begin{array}{l}-0.001^{*} \\
(-1.69)\end{array}$ \\
\hline Leverage & & & & & $\begin{array}{l}-0.07^{* * *} \\
(-6.40)\end{array}$ & $\begin{array}{c}-0.06^{* * *} \\
(-6.14)\end{array}$ & & $\begin{array}{c}- \\
0.05^{* * *} \\
(-3.18)\end{array}$ \\
\hline ES & $\begin{array}{l}-0.05 \\
(-1.06)\end{array}$ & & & & & & & \\
\hline Volatility & & $\begin{array}{c}0.10 \\
(0.17)\end{array}$ & & & & & & $\begin{array}{c}-0.26 \\
(-0.42)\end{array}$ \\
\hline Beta & & & & $\begin{array}{l}-0.32^{* *} \\
(-2.24)\end{array}$ & & & & \\
\hline Log Assets & & & & & & & $\begin{array}{l}-0.12^{* * *} \\
(-5.48)\end{array}$ & $\begin{array}{c}-0.04 \\
(-1.18)\end{array}$ \\
\hline $\begin{array}{l}\text { Industry } \\
\text { Dummies } \\
\text { Constant }\end{array}$ & $\begin{array}{l}-0.35^{\star * *} \\
(-2.66)\end{array}$ & $\begin{array}{c}-0.48^{* * *} \\
(-3.93)\end{array}$ & $\begin{array}{c}-0.14 \\
(-1.02)\end{array}$ & $\begin{array}{c}-0.18 \\
(-1.29)\end{array}$ & $\begin{array}{c}-0.06 \\
(-0.69)\end{array}$ & $\begin{array}{c}0.12 \\
(1.01)\end{array}$ & $\begin{array}{c}0.87^{* * *} \\
(3.48)\end{array}$ & $\begin{array}{c}0.5 \\
(1.48)\end{array}$ \\
\hline Other & $\begin{array}{l}-0.01 \\
(-0.10)\end{array}$ & $\begin{array}{l}-0.08 \\
(-0.7)\end{array}$ & $\begin{array}{c}0.04 \\
(0.41)\end{array}$ & $\begin{array}{c}0.40 \\
(0.40)\end{array}$ & $\begin{array}{l}-0.26^{* * *} \\
(-2.92)\end{array}$ & $\begin{array}{l}-0.18^{*} \\
(-1.82)\end{array}$ & $\begin{array}{l}-0.28^{* * *} \\
(-2.90)\end{array}$ & $\begin{array}{l}-0.18^{*} \\
(-1.82)\end{array}$ \\
\hline Insurance & $\begin{array}{c}0.03 \\
(0.27)\end{array}$ & $\begin{array}{c}0.01 \\
(0.14)\end{array}$ & $\begin{array}{c}-0.02 \\
(-0.21)\end{array}$ & $\begin{array}{l}-0.01 \\
(-0.14)\end{array}$ & $\begin{array}{c}-0.11 \\
(-1.42)\end{array}$ & $\begin{array}{c}-0.12 \\
(-1.58)\end{array}$ & $\begin{array}{l}-0.09 \\
(-1.03)\end{array}$ & $\begin{array}{c}-0.13 \\
(-1.60)\end{array}$ \\
\hline Broker & $\begin{array}{l}-0.14 \\
(-0.87)\end{array}$ & $\begin{array}{l}-0.22 \\
(-1.42)\end{array}$ & $\begin{array}{c}0.08 \\
(0.49)\end{array}$ & $\begin{array}{c}0.03 \\
(0.18)\end{array}$ & $\begin{array}{l}-0.07 \\
(-0.58)\end{array}$ & $\begin{array}{c}0.10 \\
(1.68)\end{array}$ & $\begin{array}{l}-0.23^{*} \\
(-1.85)\end{array}$ & $\begin{array}{c}0.10 \\
(0.68)\end{array}$ \\
\hline
\end{tabular}




\begin{tabular}{lcccccccc}
\hline No. Obs & 102 & 102 & 102 & 102 & 101 & 101 & 101 & 101 \\
& & & & & & & & \\
Pseudo R & $3.95 \%$ & $2.95 \%$ & $10.21 \%$ & $7.49 \%$ & $43.95 \%$ & $47.7 \%$ & $28.87 \%$ & $49.05 \%$ \\
\hline
\end{tabular}

Note: ${ }^{*} p<0.05 ;{ }^{* *} p<0.01 ;{ }^{* *} p<0.001$

Standard errors in parenthesis

Dependent Variable: Stock market returns during the crisis period (July, 2007 until December, 2008)

Andrew Haldane (2012) supports the view that regulation is too complex under the supervision of Basel, and concludes that a one factor of leverage ratio is a better indicator of crisis than any other Basel's ratios. Haldane runs logit regression for a set of 100 of the world's most complex banks, which had total assets over $\$ 100$ billions at the end of 2006, to confirm that simple un-weighted leverage ratio is significant at the level of 1 percent to predict banks' failure compared to risk-weighted capital ratio. That presents a contradiction to the risk-sensitivity doctrine as the complexity in Basel framework comes from risk-weighting assets models which intended to predict banks failures. The results are shown in Table 2.13. Another source of the complexity is the definition of capital. Haldane attempts to show how simple measures of capital can beat complex ones, therefore, he examined a set of measures of capital to predict banks' failures. He finds that Core-Tier I and Market simple leverage ratios outperform CoreTier I and market risk-based leverage ratios as shown in Table 2.14. In addition, Haldane considers a set of predictors of bank failure other than just capital which are associated with capital, asset quality, management, earnings, and liquidity. He finds all predictors are correctly signed but not all are significant as shown in Table 2.15. 
Table 2.13: Estimation results for simple versus complex leverage for Andrew Haldane (2012)

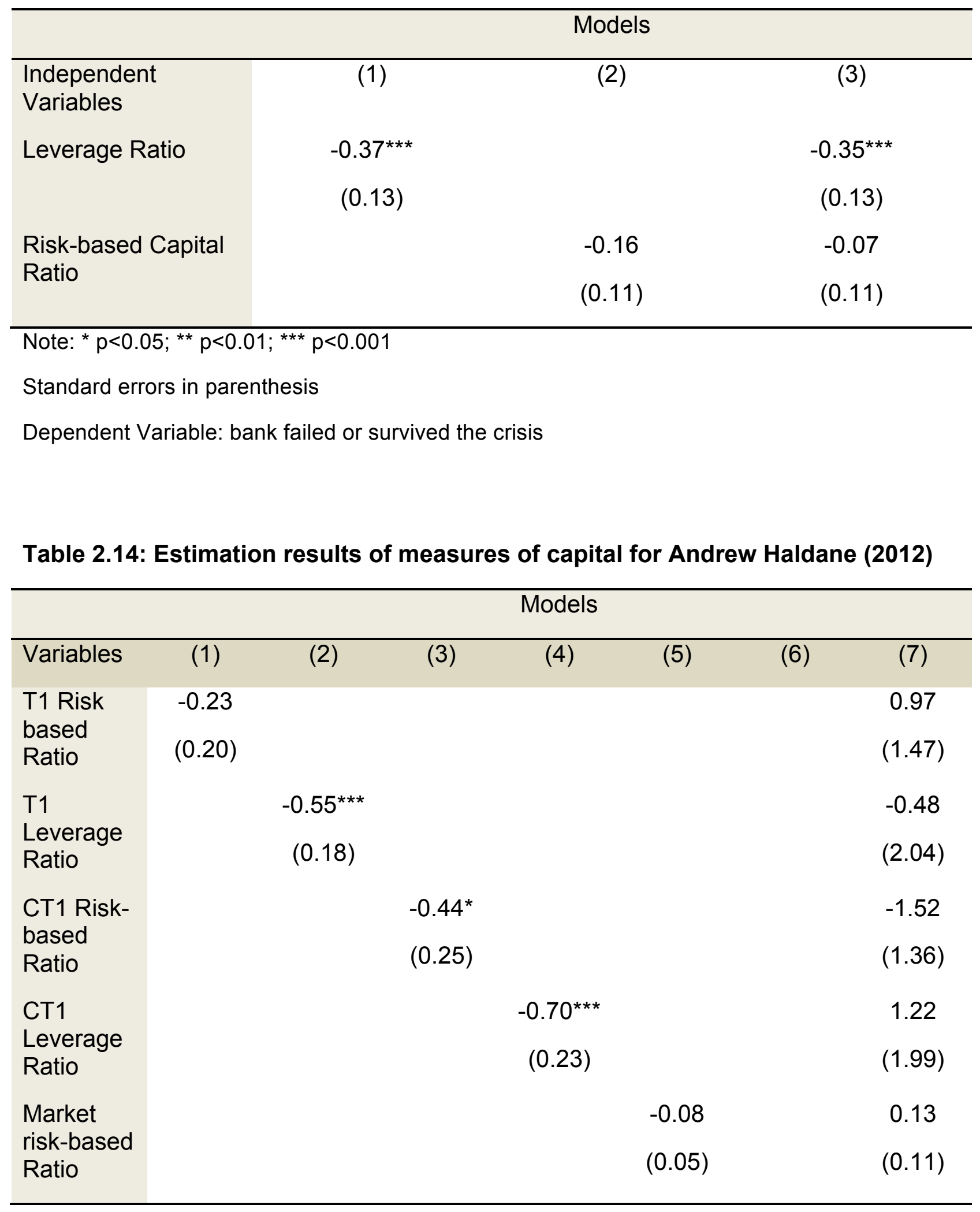




\begin{tabular}{llllllll}
\hline $\begin{array}{l}\text { Market } \\
\text { Leverage }\end{array}$ & & & & & & $-0.20^{\star * *}$ & $-0.35^{*}$ \\
Ratio & & & & & & $(0.06)$ & $(0.20)$ \\
$\begin{array}{l}\text { McFadden } \\
\mathrm{R}^{2}\end{array}$ & 0.023 & 0.177 & 0.070 & 0.203 & 0.071 & 0.216 & 0.317 \\
\hline
\end{tabular}

Note: ${ }^{*} p<0.05 ;{ }^{* *} p<0.01 ;{ }^{* * *} p<0.001$

Standard errors in parenthesis

Dependent Variable: bank failed or survived the crisis

Table 2.15: Estimation results of other predictors than just capital for Andrew Haldane (2012)

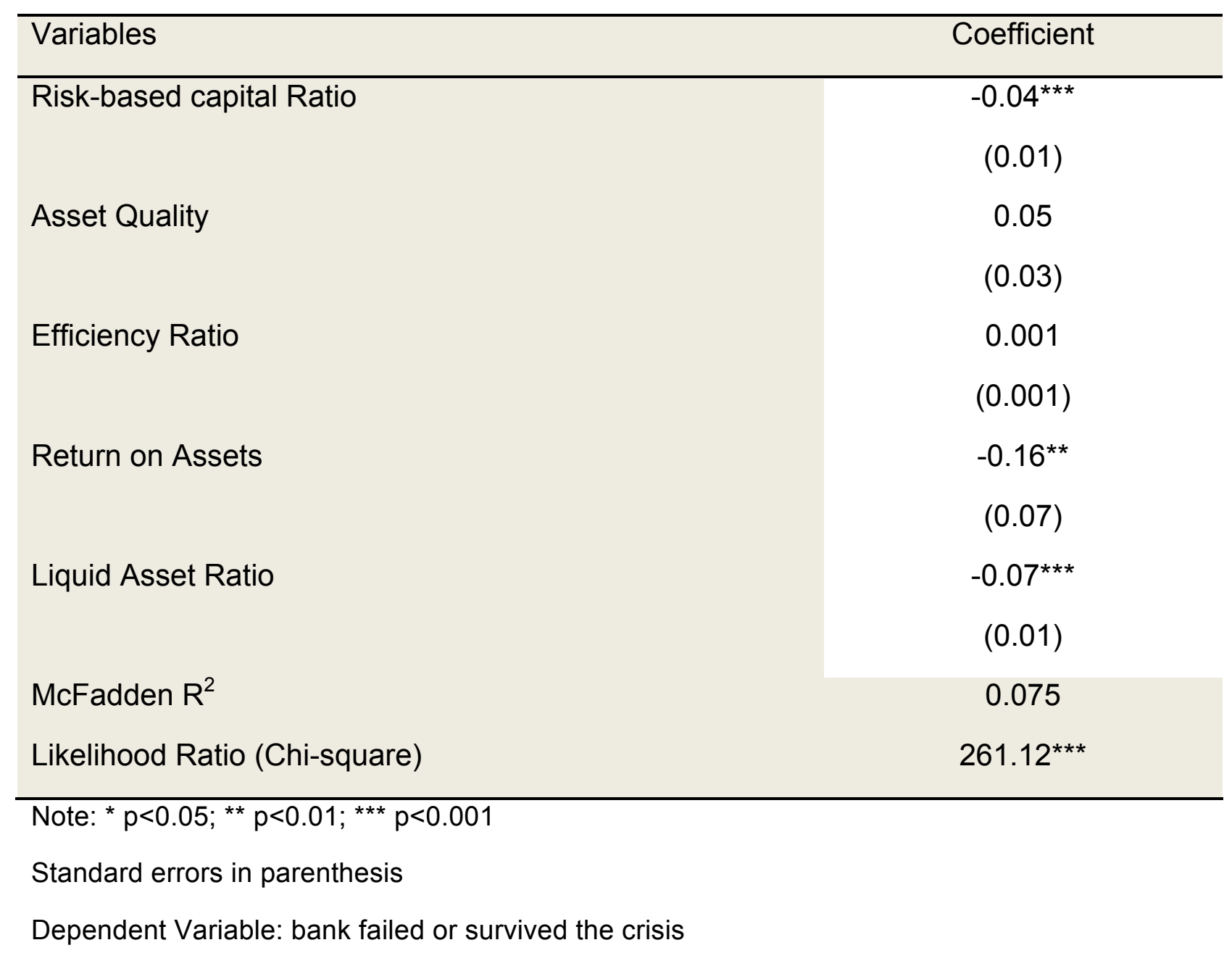


Finally, Table 2.16 summarizes some of the similarities and differences among studies covered in this dissertation. The relationship between equity and total capital is an important factor that most of the literature finds as the most significant to predicting a financial crisis. However, different approaches have been conducted to quantify the ratio of leverage or equivalently the ratio that defines the relationship between equity and total capital. For example, Acharya et al. use market value of equity and quasimarket value of assets, while Haldane and Demirgus-Kunt et al. use book-valued of equity and risk-weighted assets to measure the ratio of leverage. Another area of dissimilarities is the way of measuring the crisis incidence variables. Acharya et al. and Demirgus-Kunt et al. use the percentage change in stock market prices between the maximum and minimum, while Adrian and Brunnermeier use asset returns and Haldane use whether a firm went bankrupt during the crisis as a measure of crisis incidence variable. In addition, they differ in what methodology should be used and the lag time period that needs to be considered across studies.

Table 2.16: Summary of the studies of financial crises using financial ratios covered in this dissertation.

\begin{tabular}{|l|l|l|l|l|}
\hline Study & $\begin{array}{l}\text { Dependent } \\
\text { Variable }\end{array}$ & Independent Variables & Sample & Methodology \\
\hline $\begin{array}{l}\text { Edward } \\
\text { Altman } \\
(1968)\end{array}$ & Fail or non-Fail & $\mathrm{X}_{1}=$ Working & Financial & Multiple \\
capital/total assets & ratios data & discriminant \\
"Z-Score & & $\mathrm{X}_{2}=$ retained & from 1946 & statistical \\
Model" & & earnings/total assets & on a yearly & \\
& & $X_{3}=$ earnings before & basis for a & sample of \\
& & interest and taxes/total & s6 firms & \\
& & assets & divided into & \\
& & $X_{4}=$ book value & two groups & \\
& &
\end{tabular}




\begin{tabular}{|c|c|c|c|c|}
\hline & & $\begin{array}{l}\text { equity/book value of } \\
\text { total liability } \\
X_{5}=\text { sales/total assets }\end{array}$ & & \\
\hline $\begin{array}{l}\text { Altman, } \\
\text { Haldeman, } \\
\text { and } \\
\text { Narayanan } \\
\text { (1977) } \\
\text { "ZETA } \\
\text { Model" }\end{array}$ & Fail or non-Fail & $\begin{array}{l}\text { Seven financial ratios } \\
\text { out of selected } 28 \\
\text { variables: } \\
X_{1}=\text { Earnings before } \\
\text { interest and taxes/total } \\
\text { asset } \\
X_{2}=\text { Stability of } \\
\text { earnings } \\
X_{3}=\text { Earning before } \\
\text { interest and taxes/total } \\
\text { interest payments } \\
X_{4}=\text { Retained } \\
\text { earnings/total assets } \\
X_{5}=\text { Current assets/ } \\
\text { current liabilities } \\
X_{6}=\text { Common } \\
\text { equity/total capital } \\
X_{7}=\text { Total assets }\end{array}$ & $\begin{array}{l}\text { Financial } \\
\text { ratios data } \\
\text { for } 111 \\
\text { firms } \\
\text { between } \\
1969 \text { and } \\
1975 \text { and } \\
\text { created two } \\
\text { groups } \\
\text { including } 53 \\
\text { bankrupt } \\
\text { firms and } \\
58 \text { non- } \\
\text { bankrupt } \\
\text { firms. }\end{array}$ & $\begin{array}{l}\text { Multiple } \\
\text { discriminant } \\
\text { statistical }\end{array}$ \\
\hline $\begin{array}{l}\text { Demirgus- } \\
\text { Kunt, } \\
\text { Detragiache, } \\
\text { and } \\
\text { Merrouche in } \\
2010\end{array}$ & $\begin{array}{l}\text { The percent } \\
\text { change in banks' } \\
\text { stock prices } \\
\text { during the crisis } \\
\text { periods (2007Q3- } \\
\text { 2009Q1) }\end{array}$ & $\begin{array}{l}X_{1}=\text { Basel risk- } \\
\text { adjusted ratio } \\
X_{2}=\text { Leverage ratio } \\
X_{3}=\text { Liquidity } \\
X_{4}=\text { Deposits } \\
X_{5}=\text { Net Loans } \\
X_{6}=\text { Provisions } \\
X_{7}=\text { Size } \\
X_{8}=\text { MV/BV of Equity } \\
X_{9}=\text { Price-earnings }\end{array}$ & $\begin{array}{l}381 \text { banks } \\
\text { in } 12 \\
\text { countries } \\
\text { during the } \\
\text { period } \\
2005 \text { 1 to } \\
2009 Q 1\end{array}$ & $\begin{array}{l}\text { OLS cross- } \\
\text { sectional } \\
\text { analysis }\end{array}$ \\
\hline
\end{tabular}




\begin{tabular}{|c|c|c|c|c|}
\hline & & $\mathrm{X}_{10}=$ Beta & & \\
\hline $\begin{array}{l}\text { Berger and } \\
\text { Bouwman } \\
(2009)\end{array}$ & $\begin{array}{l}\mathrm{Y}_{1}=\text { Survive the } \\
\text { banking or } \\
\text { marketing crisis } \\
\mathrm{Y}_{2}=\text { The percent } \\
\text { change in gross } \\
\text { total assets as a } \\
\text { measure of } \\
\text { percent change in } \\
\text { market share } \\
\mathrm{Y}_{3}=\text { The percent } \\
\text { change in liquidity } \\
\text { creation as a } \\
\text { measure of } \\
\text { percent change in } \\
\text { market share. } \\
\mathrm{Y}_{4}=\text { The percent } \\
\text { change in return } \\
\text { on equity. }\end{array}$ & $\begin{array}{l}\text { Types of capital ratio, } \\
\text { log of total assets, and } \\
\text { a set of control } \\
\text { variables }\end{array}$ & $\begin{array}{l}\text { Financial } \\
\text { data from } \\
\text { 1984Q1 to } \\
\text { 2008Q4 for } \\
\text { every } \\
\text { commercial } \\
\text { and credit } \\
\text { card bank } \\
\text { in the US } \\
\text { (18326 } \\
\text { banks) on a } \\
\text { quarterly } \\
\text { basis and } \\
\text { created } \\
\text { three } \\
\text { subsamples } \\
\text { according } \\
\text { to the } \\
\text { banks' } \\
\text { sizes } \\
\text { (small, } \\
\text { medium, } \\
\text { and large) }\end{array}$ & $\begin{array}{l}\text { Logit } \\
\text { Analysis }\end{array}$ \\
\hline $\begin{array}{l}\text { Gregor Weib, } \\
\text { Denefa } \\
\text { Bostandzic, } \\
\text { and Sascha } \\
\text { Neumann } \\
(2013)\end{array}$ & $\begin{array}{l}\text { The change in } \\
\text { Lower Tail } \\
\text { Dependence } \\
\text { (LTD) and } \\
\text { Marginal } \\
\text { Expected Shortfall } \\
\text { (MES). } \\
\text { Approaches to } \\
\text { quantify MES and } \\
\text { LTD as introduced } \\
\text { by Acharya et al. } \\
\text { (2010), and } \\
\text { Weibet al. (2012) } \\
\text { respectively. }\end{array}$ & $\begin{array}{l}\text { A set of control } \\
\text { variables associated } \\
\text { with banks' } \\
\text { characteristics } \\
\text { including profitability, } \\
\text { size, and leverage in } \\
\text { addition to public } \\
\text { safety-net guarantees } \\
\text { and macroeconomic } \\
\text { fundamentals for all } \\
\text { countries }\end{array}$ & $\begin{array}{l}888 \text { banks } \\
\text { for the } \\
\text { collapse of } \\
\text { Lehman } \\
\text { Brothers. } \\
\text { They use } \\
\text { local and } \\
\text { global } \\
\text { systemic } \\
\text { risks over } 7 \\
\text { events } \\
\text { starting } \\
\text { from } \\
\text { Mexico to } \\
\text { Lehman } \\
\text { Brothers } \\
\text { default. }\end{array}$ & $\begin{array}{l}\text { OLS } \\
\text { regression. }\end{array}$ \\
\hline $\begin{array}{l}\text { Blundell- } \\
\text { Wignall and } \\
\text { Roulet (2013) }\end{array}$ & $\begin{array}{l}\text { Distance to } \\
\text { default (DTD) as } \\
\text { measured by the }\end{array}$ & $\begin{array}{l}\text { A set of macro- and } \\
\text { micro-variables, which }\end{array}$ & $\begin{array}{l}94 \text { banks } \\
\text { over the } \\
\text { period } 2004 \\
\end{array}$ & $\begin{array}{l}\text { Panel } \\
\text { regression } \\
\text { (OLS) }\end{array}$ \\
\hline
\end{tabular}




\begin{tabular}{|c|c|c|c|c|}
\hline & $\begin{array}{l}\text { number of } \\
\text { standard deviation } \\
\text { away from the } \\
\text { default point. } \\
\text { Default is defined } \\
\text { as book-valued } \\
\text { debt } \geq \text { market- } \\
\text { valued assets. }\end{array}$ & $\begin{array}{l}\text { include: } \\
X_{1}=\text { Size } \\
X_{2}=\text { Simple leverage } \\
X_{3}=\text { Tier I leverage } \\
X_{4}=\text { Interbank assets } \\
X_{5}=\text { Total debt/total } \\
\text { asset } \\
X_{6}=\text { Gross market } \\
\text { value/total assets }\end{array}$ & to 2011 & $\begin{array}{l}\text { univariate } \\
\text { and } \\
\text { multivariate }\end{array}$ \\
\hline $\begin{array}{l}\text { Adrian and } \\
\text { Brunnermeier } \\
\text { (2011) }\end{array}$ & $\begin{array}{l}\text { Systemic risk } \\
\text { measure } \Delta \text { CoVaR } \\
\text { is the difference } \\
\text { between CoVaR } \\
\text { conditional on firm } \\
\text { under distress } \\
\text { and median state. } \\
\text { The estimation of } \\
\Delta \text { CoVaR is based } \\
\text { on weekly } \\
\text { changes in market } \\
\text { value of assets. }\end{array}$ & $\begin{array}{l}X_{1}=\text { Leverage }, \\
X_{2}=\text { Firm's size } \\
X_{3}=\text { Maturity } \\
\text { mismatch } \\
X_{4}=\text { Market-to-book } \\
X_{5}=\text { Market beta } \\
X_{6}=V a R \text { as } F(\text { macro } \\
\text { control variables }) \\
X_{7}=\text { log of book- } \\
\text { valued of equity }\end{array}$ & $\begin{array}{l}\text { Weekly } \\
\text { data for the } \\
\text { changes in } \\
\text { market } \\
\text { value of } \\
\text { assets and } \\
\text { quarterly } \\
\text { data for } \\
\text { financial } \\
\text { reports } \\
\text { from } \\
\text { 1986Q1- } \\
2010 Q 4 \text { for } \\
\text { all publicly } \\
\text { traded } \\
\text { financial } \\
\text { institutions. }\end{array}$ & $\begin{array}{l}\text { Quantile and } \\
\text { panel } \\
\text { regressions. }\end{array}$ \\
\hline $\begin{array}{l}\text { Acharya, } \\
\text { Pedersen, } \\
\text { Philippon, } \\
\text { and } \\
\text { Richardson } \\
(2010)\end{array}$ & $\begin{array}{l}Y_{1}=\text { The capital } \\
\text { shortfalls at large } \\
\text { firms during the } \\
\text { crisis measured } \\
\text { by the stress test } \\
Y_{2}=\text { The drop in } \\
\text { equity values of } \\
\text { large firms during } \\
\text { the crisis. (Jul } \\
2007 \text { - Dec 2008) } \\
Y_{3}=\text { The increase } \\
\text { in credit risk } \\
\text { estimated from } \\
\text { CDS returns of }\end{array}$ & $\begin{array}{l}X_{1}=\text { Leverage ratio } \\
X_{2}=\text { Marginal } \\
\text { expected shortfall } \\
X_{3}=\text { Expected } \\
\text { shortfall } \\
X_{4}=\text { Beta } \\
X_{5}=\text { log Assets } \\
X_{6}=\text { Volatility }\end{array}$ & $\begin{array}{l}102 \\
\text { financial } \\
\text { firms }\end{array}$ & $\begin{array}{l}\text { OLS } \\
\text { regression, } \\
\text { and Tobit } \\
\text { regression } \\
\text { analysis }\end{array}$ \\
\hline
\end{tabular}




\begin{tabular}{|c|c|c|c|c|}
\hline & $\begin{array}{l}\text { large firms during } \\
\text { the crisis. }\end{array}$ & & & \\
\hline $\begin{array}{l}\text { Andrew } \\
\text { Haldane } \\
(2012)\end{array}$ & $\begin{array}{l}\text { Failed and } \\
\text { surviving }\end{array}$ & $\begin{array}{l}X_{1}=\text { Simple leverage } \\
X_{2}=\text { Tier I risk-based } \\
\text { leverage } \\
X_{3}=\text { Asset quality } \\
X_{4}=\text { Efficiency ratio } \\
X_{5}=\text { Return on assets } \\
X_{6}=\text { Liquidity asset } \\
\text { ratio }\end{array}$ & $\begin{array}{l}\text { A set of } 100 \\
\text { of the } \\
\text { world's } \\
\text { most } \\
\text { complex } \\
\text { banks, } \\
\text { which had } \\
\text { total assets } \\
\text { over } 100 \\
\text { billions at } \\
\text { the end of } \\
2006\end{array}$ & $\begin{array}{l}\text { Logit } \\
\text { regression }\end{array}$ \\
\hline
\end{tabular}




\section{METHODOLOGY}

\subsection{RESEARCH DESGIN}

We conducted our research in two parts. Initially, we use a correlational quantitative design using structural equation modeling (SEM) to analyze historical data and test a theoretical model that presents our view about the relationships between independent and dependent variables to examine if it fits the data. This is especially important because correlational and historical data do not allow for hypothesis testing or causal inference due to a lack of experimental design. However, a theoretical model can be constructed for this data and thus, a hypothesis can be tested.

Subsequently, we use multivariable fractional polynomial estimation technique (MFP) to overcome the inadequacy of linear models and take advantage of its features of including all interested variables "full model" and the implementation of a backward elimination process. We use MFP to test the relationships between continuous covariates and outcomes as introduced by (Royston, 1994) and modified by (Sauerbrei, 1999).

\subsection{RATIONALE FOR A QUANTITATIVE FRAMEWORK}

In the first part of this analysis, we use structural equation modeling (SEM) to test our exploratory hypothetical model that explains the relationships between the financial statement items in order to predict the change of stock market prices. A hypothetical causal model is first operationalized to test the proposed model for significant relationships between variables using the suggested theory and concepts. Employing 
the SEM technique achieves this task by testing the data against the best-fit model (Bollen, 1993).

Additionally, SEM technique requires the construction of endogenous and exogenous variables in order to define the relationship between those variables. In regression models, the dependent variable (DV) regresses on independent variable (IV) which means the IV predicts DV. However, with SEM, endogenous variables can only regress upon exogenous variables, while exogenous variables cannot regress on endogenous variables. Endogenous variables can also be both dependent and independent variables at the same time which makes SEM technique more general than regression.

Two types of analyses are conducted at the same time using SEM technique not available with other techniques including path and factor analysis. The first analysis shows how likely the causal relationships are between endogenous and exogenous variables which presents the similarity between SEM and path analyses. The second analysis shows the relationships between unobserved variables and their indicators which presents the similarity between SEM and factor analyses.

In the second part of the analysis, we use fractional polynomials framework (FP) to overcome the weaknesses of linear and quadratic functions as both may produce misleading conclusions if they are not the proper functions. We believe that an intermediate relationship exists between polynomials and non-linear curves in between continuous covariates. 
One advantage of multivariable fractional polynomials (MFP) algorithm technique is that is combines both backward elimination and FP function selection in a systematic way for continuous covariates. The MFP model starts with a full model (over-fitting). However, a sequence of tests will be conducted in order to keep type I error at the chosen level of significance (i.e., 0.05) in order to reduce the over-fitting problem. The

first test decides whether to include the continuous covariates by testing FP2 against the null model, which is not to include them. The covariate will be included if it is significant. Then the technique moves on to the nonlinearity test where FP2 is tested against a straight line. The MFP algorithm keeps the techniques of selection and transformation for each covariate and adjusts other covariates until there are no more covariates to exclude or change.

\subsection{RESEARCH QUESTION}

In this dissertation, we empirically investigate what variables from a firm's financial statement significantly predict an individual firm's vulnerability to a financial crisis? In order to answer this question, this analysis begins by selecting a variety of variables from a firm's financial statement associated with the firm's performance, profitability and liquidity. Second, an investigation will be carried out using Structural Equation Modeling and Multivariable Fractional Polynomials testing the effects of those variables on two dependent variable measures for the percentage of change in stock market price over varying time periods.

$\mathrm{H} 1_{\text {Null: }}$ There is no relationship over varying time lengths between independent variables from financial statements and the dependent variables. 
- Dependent Variables: two different measures for the percentage change of stock market price.

- Predictor Variables or Mediating Variables: average level or accumulated timeweighted rate of change of financial statements variables.

- Statistical Analysis: Structural Equation Modeling and Multivariable Fractional Polynomials.

\section{$3.4 \quad$ POPULATION AND SAMPLE}

The population included in this study consists of the financial industry which, in 2004, represented 20 percent of the market capitalization of the S\&P 500 in the United States. ${ }^{1}$ This active industry serves as the intermediary between lenders and borrowers of capital or cash. In fact, the financial industry is the main source of liquidity for both financial and real economies. The financial market includes commercial banks, investment banks, insurance companies, real estate, and others.

According to Acharya et al. (2010) a list of 102 financial firms was selected out of 1226 financial institutions whose market capitalization exceeded \$5 billion in 2007. Firms were then categorized into four groups including Depository, Non-Depository, Insurance, and Broker-Dealer firms. ${ }^{2}$ In this study, at least seven financial institutions from each category were randomly chosen according to data availability and fewer missing values if necessarily for targeted independent variables to end up with 52 financial firms as our sample. In this sample, each category is illustrated with the following proportions: 93 percent depository institutions including Bank of America and

\footnotetext{
1 See investor.com (2004) "The Mistakes of Our Grandparents"

${ }^{2}$ For more details see Acharya et al. (2010)
} 
Citigroup (hereafter called Banks); 33 percent non-depository institutions including Federal National Mortgage and Blackrock (hereafter called Others); 25 percent of insurance institutions including AIG and Berkshire (hereafter called Insurances); and 70 percent broker-dealer institutions including Goldman Sachs and Lehman Brothers (hereafter called Brokers). Table 3.1 in Appendix A shows the list of the U.S. financial institutions used in this dissertation.

In this study, we use quarterly adjusted stock market prices and financial statement items data on a quarterly basis since it is the shortest period for publicly traded financial institutions to report on these statements to the Securities and Exchange Commission (SEC). We collected data from Bloomberg terminal at Claremont Graduate University for the period between the third quarter of 2002 and the fourth quarter of 2011.

The descriptive statistics for each category with respect to their market capitalization over the period before the recent crash that started in the third quarter of 2007 are shown in Table 3.2 below. In addition, the correlation figures between the changes of stock prices for financial firms and change of market index price for each category over varying periods are shown in Table 3.3 below. The strongest correlation exists between brokers and benchmark (S\&P) before and after the crisis ( 0.65 and 0.86 respectively) illustrating how volatile this group was relative to the rest. The highest increased percentage in correlation coefficients before and after the crisis exists between others and benchmark, while the next highest increase exists between brokers and benchmark (66 percent and 32 percent, respectively). This also reflects how 
perceptive the public becomes toward financial institutions after the crisis as all categories ended up more correlated with the index than before the crisis.

Table 3.2: This table shows the descriptive statistics for each category with respect to their market capitalization over the pre-crisis period from 2002q3 to 2007q3.

\begin{tabular}{llllll}
\hline Category & $\mathrm{N}$ & Mean & $\mathrm{SD}$ & Min & Max \\
\hline Banks & 550 & 36,907 & $57,744.89$ & $1,384.779$ & $273,598.1$ \\
Others & 161 & $25,161.87$ & $22,212.13$ & 771.3664 & $72,808.2$ \\
Insurances & 189 & $45,073.41$ & $50,865.87$ & $1,543.555$ & $183,394.2$ \\
Brokers & 147 & $31,977.5$ & $23,749.62$ & $1,505.643$ & $94,264.58$ \\
\hline
\end{tabular}

Table 3.3: This table shows the correlation coefficients between the changes of stock market prices of financial institutions and the change of market index price (S\&P 500) by category over different time periods.

\begin{tabular}{llll}
\hline Category & Before 2007q3 & 2007q3-2009q1 & After 2009q1 \\
\hline Banks & .50 & .21 & .58 \\
Others & .33 & .39 & .55 \\
Insurances & .52 & .43 & .57 \\
Brokers & .65 & .32 & .86 \\
\hline
\end{tabular}




\subsection{OPERATIONALIZATION OF VARIABLES}

\subsubsection{DEPENDENT VARIABLES}

We use the percent change of quarterly adjusted stock market prices during the crisis to measure the dependent variable because these prices are available and more actively traded than other measures such as bonds' prices or credit default swaps. Moreover, these prices are used to measure how public evaluates an individual firm according to its performance, future growth, and ability to generate profits. Since there is no one right way to measure the change of stock market prices, we operationalize the dependent variable in two different methods. The Table in Appendix B shows the list of all variables used in this dissertation and their descriptions.

\section{THE PERCENT CHANGE IN STOCK MARKET PRICE BETWEEN MAXIMUM AND MINIMUM POINTS (Y1)}

This research attempts to identify variables that could have better predicted which financial institutions would suffer the greatest negative impact as a result of the 2008 financial crisis. We first compute the percent change of stock market price between the maximum and minimum points during the systemic event in 2008 . We define third quarter of 2007 as the peak point and first quarter of 2009 as the lowest point since it has been marked by S\&P 500 index price (the benchmark of financial market). ${ }^{1}$ Figure 3.1 shows the performance of benchmark stock market price and Figure 3.2 shows the accumulative returns on firm's stock market price over the period of this this study.

\footnotetext{
${ }^{1}$ Demirgus-Kunt et al. (2010) used the same maximum and minimum points to calculate the percent change of stock market prices as the dependent variable.
} 
The vulnerability of a firm is measured by how much its stock market price dropped during the crisis. Figure 3.3 shows the percent drop or rise of stock market price for each financial institution during the systemic crisis by suing the first measure of stock market effects of such crisis. Firms that went bankrupt or were acquired by others report 100 percent drop of stock price proved as the most vulnerable firms to the crisis, for example: WB, WAMUQ, UB, NCC, MER, LEHMQ, and CBH.

Figure 3.1: The performance of quarterly adjusted benchmark's stock market price.

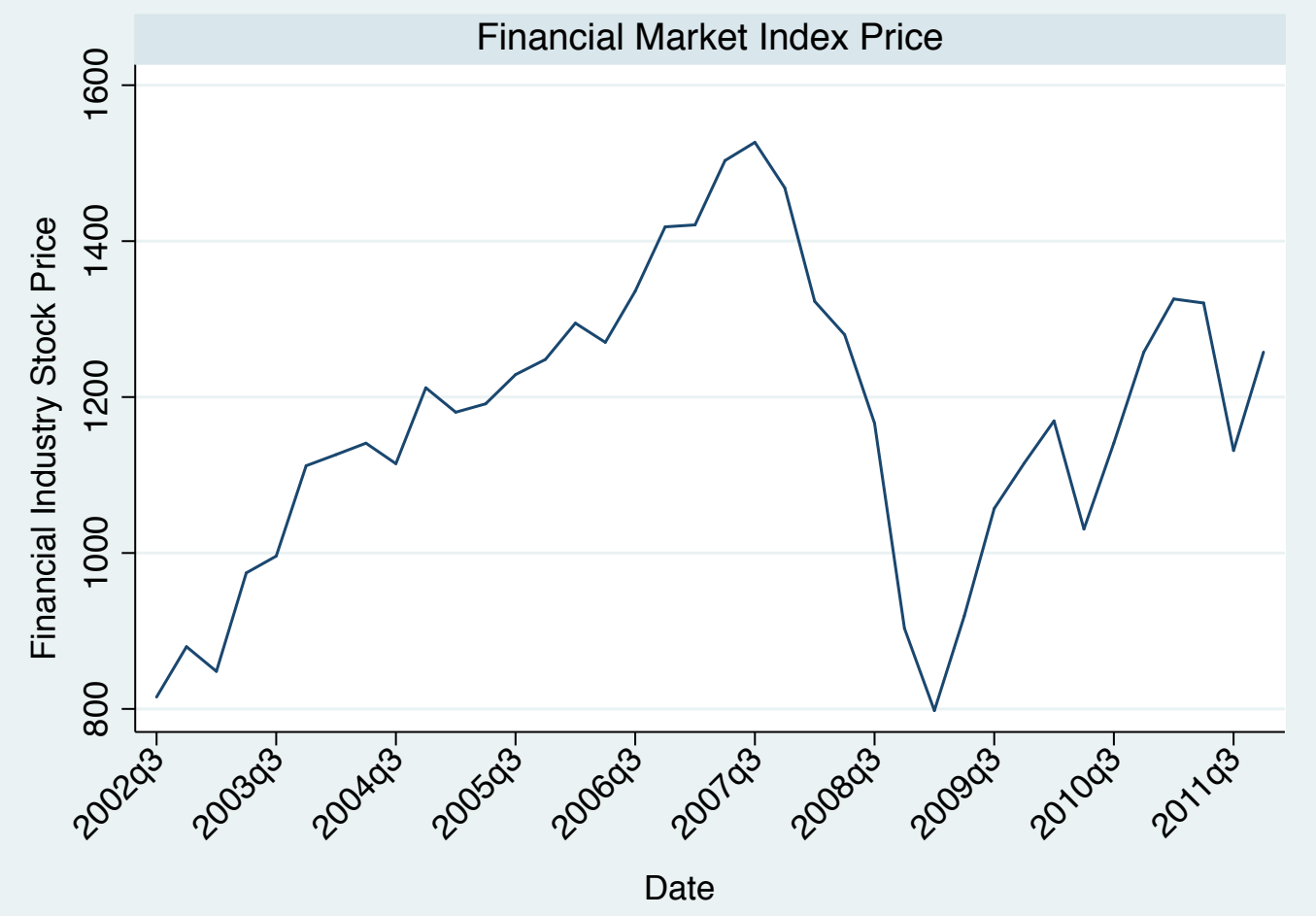


Figure 3.2: The accumulated return on stock market price.

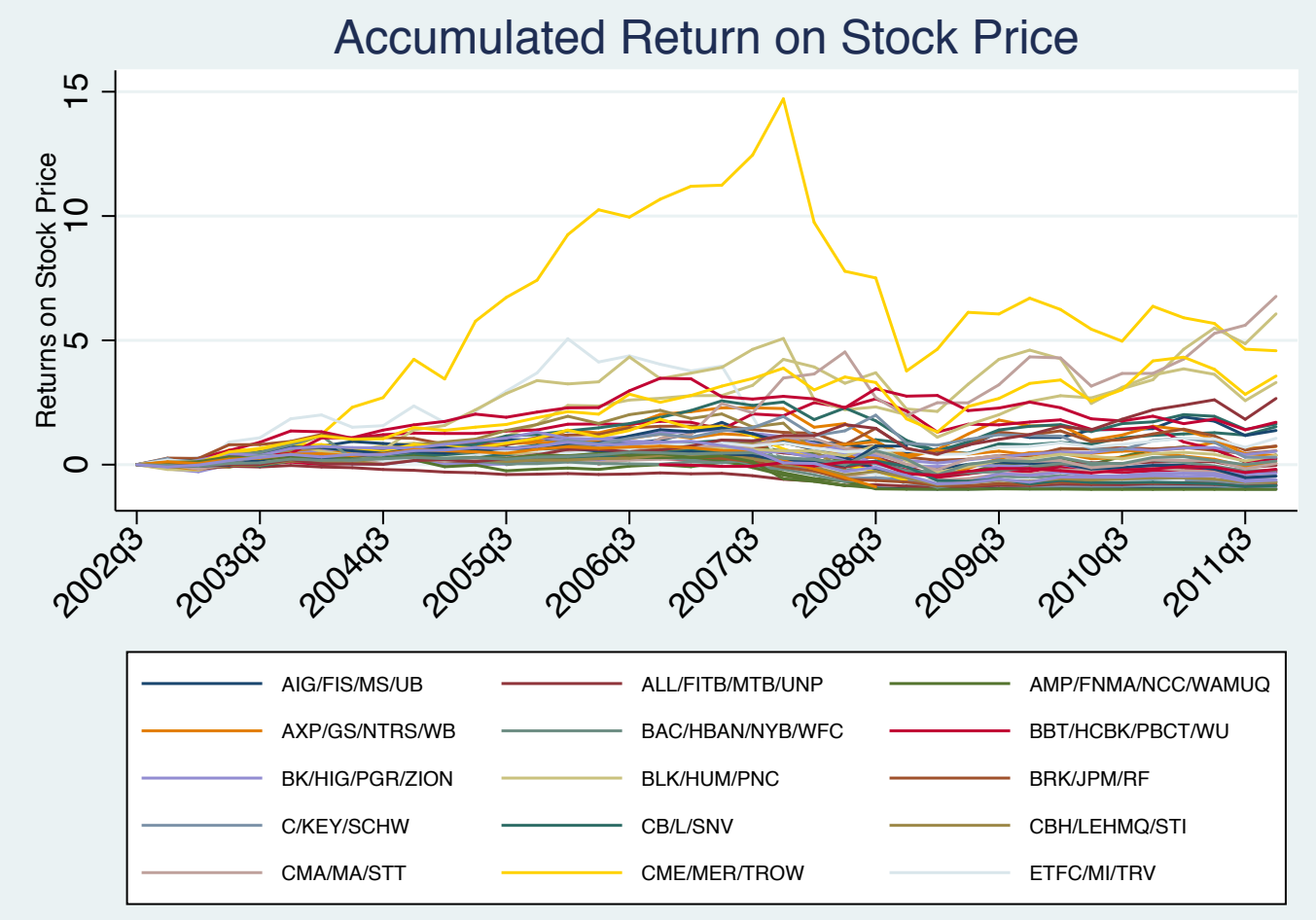

Figure 3.3: The percent change in stock market price between the maximum and minimum points during the systemic crisis in 2008.

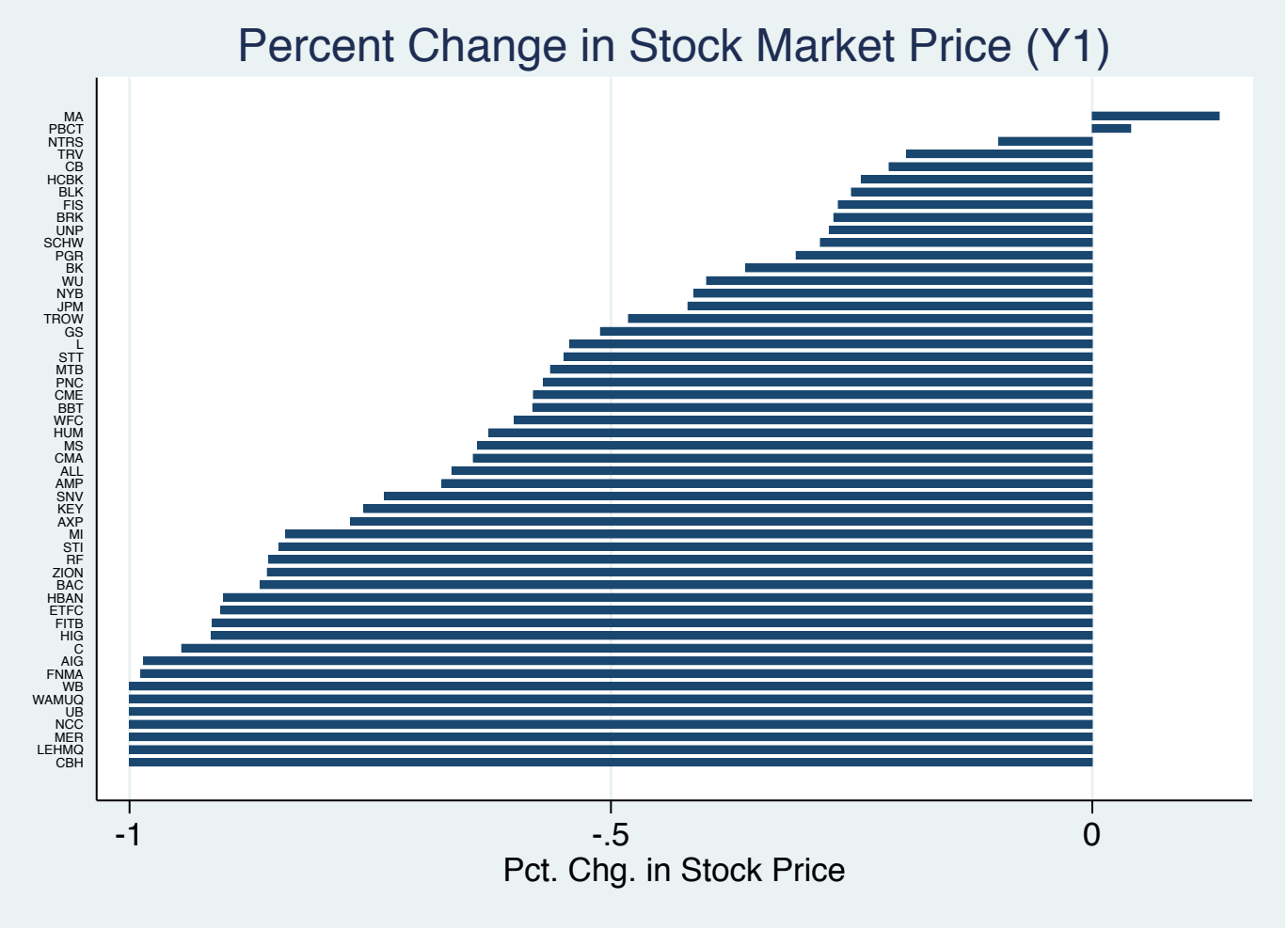




\section{THE PERCENT CHANGE IN STOCK MARKET PRICE BETWEEN AVERAGE-}

\section{MAXIMUM AND -MINIMUM POINTS (Y2)}

We compute the percent change in stock market price between the average maximum and minimum point during the financial crisis as a second method in order to overcome outlier effects in the first measure. We do this by taking the averagemaximum over three quarters $(2007 q 3-2008 q 1)$ and the average-minimum over three quarters (2008q3 - 2009q1) because as mentioned earlier, the peak occurred during the third quarter of 2007 and the lowest point occurred during the first quarter of 2009. Figure 3.4 below shows the weakness of this method as if a firm showed positive change in stock price for some quarters even though it went bankrupt later on that leads to a positive result such as that with UB. Firms that went bankrupt or were acquired by others reported as 100 percent drop in stock market price proved as the most vulnerable firms to the crisis, for example: WAMUQ, LEHMQ, and CBH. 
Figure 3.4: The percent change in stock market price between the average maximum and average minimum points during the systemic crisis in 2008.

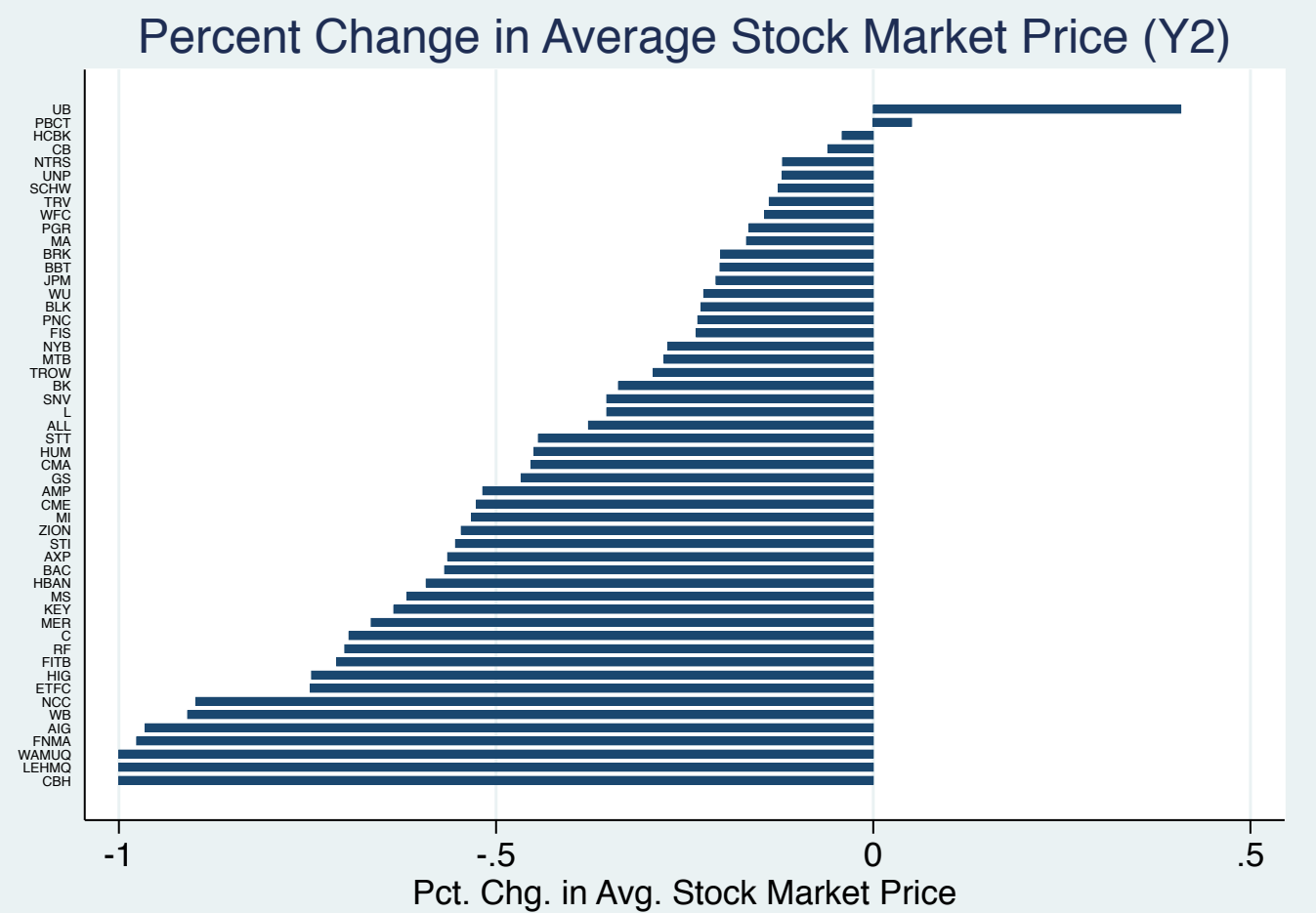

\subsubsection{INDEPENDENT VARIABLES}

Because firms' management could exploit loopholes and manipulate the information from complex financial reports such as keeping risky information hidden in a so-called 'off-balance' sheets in order to show a better position and performance than their actual position and performance, we believe those reports provide reliable data about individual institutions. Therefore, we use different ratios associated with a firm's position, performance, and profitability. However, there is no one right method to apply these ratios and no theoretical basis for a particular period that these variables can be used as early warning signals during the build-up phase of risk factors pre-crisis time. We compute these ratios with two different approaches and lagged on three different periods (4, 8, and 12 quarters). First, we calculated the average level for each ratio over 
three different lags. Second, we calculated the accumulated time-weighted rate of change for each of the ratios identified in this study over the same lags. The purpose of these different approaches and lags is to examine which set has more predictive power.

\section{FINANCIAL LEVERAGE RATIO (Lev)}

Companies will often raise debt to support their growth indicated as assets growth. Financial leverage ratio is used to illustrate the firm's capital structure and to determine to what extent a company can use debt relative to its equity. The assumption here is that the greater the stability of financial market and company earnings, the more the company can undertake risk associated with high financial leverage. On the other hand, an indication of deleveraging might be considered a red flag to investors who require growth in their companies because that shows the company is selling its assets to meet its obligations. In short, the ratio of financial leverage has been used as a measure of firm's capital structure.

Scholarly literature shows different views about the effects of leverage ratio on firms' contribution to the crises. For example, previous scholars have shown that leverage ratios can lead to loans' quality and provide banks with the necessary liquidity which will lead to lower default rates and lower risk. ${ }^{1}$ Conversely, current scholars argue that higher leverage would increase the systemic risk in the financial industry. ${ }^{2}$

Many methods can be used to calculate leverage ratios. The first and most common method divides the total book-valued of assets by total book-valued of equity which is known as the equity multiplier as shown in Adrian and Brunnermeire (2011). In

\footnotetext{
${ }^{1}$ See Calomiris and Kahn (1991) and Diamond and Rajan (2001).

2 See Acharya et al. (2010), Beltratti and Stulz (2012) and Brunnermeire et al (2012).
} 
this instance, the lower the ratio, the better the firm's position. Another method is to use market-valued of equity instead of book-valued of equity in the denominator, while quasi-market value of assets is used instead of book-valued of assets in the numerator as illustrated in Acharya et al. (2010). Others use risk-weighted assets instead of unweighted assets or use both as control variables as shown in Demirgus-Kunt et al. (2010). In this dissertation, leverage ratio is computed as the total short- and long-term debts scaled by total capital which includes both short- and long-term debts and total equity as shown below. Thus, a firm that reports a huge loss would show lower value of equity via retained earnings factor and consequently lower value in the denominator to increase the leverage ratio.

Total Debt $/$ Total Capital $=$

(Current Liability + Long Term Debt) / (Current Liability + Long Term Debt + Equity)

Figure 3.5a shows firms' average levels of financial leverage ratio over eight quarters lag pre-crisis event in $2007 q 3$. Figure $3.5 a$ shows a group of financial institutions that went bankrupt or acquired by others located on top of the list such as WU, MS, LEHMQ, and MER. Figure 3.5b shows firm's accumulated change of leverage ratio over eight quarters pre-crisis event. Figure $3.5 \mathrm{~b}$ shows what both positive and negative rates of change have upon 'firms went bankrupt'. 
Figure 3.5a: Firms' average levels of financial leverage ratio.

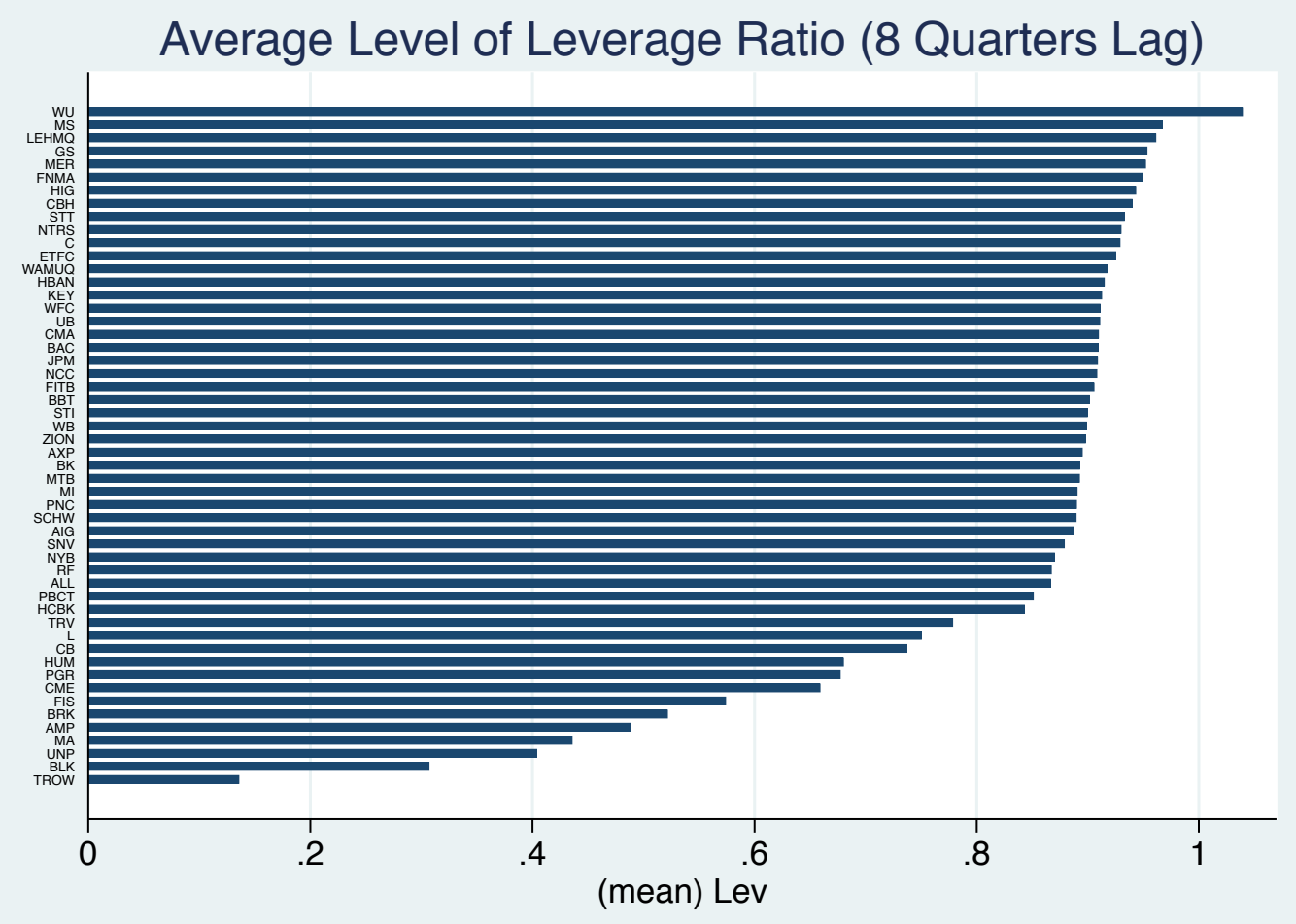

Figure 3.5b: Firm's accumulated rate of change of leverage ratio.

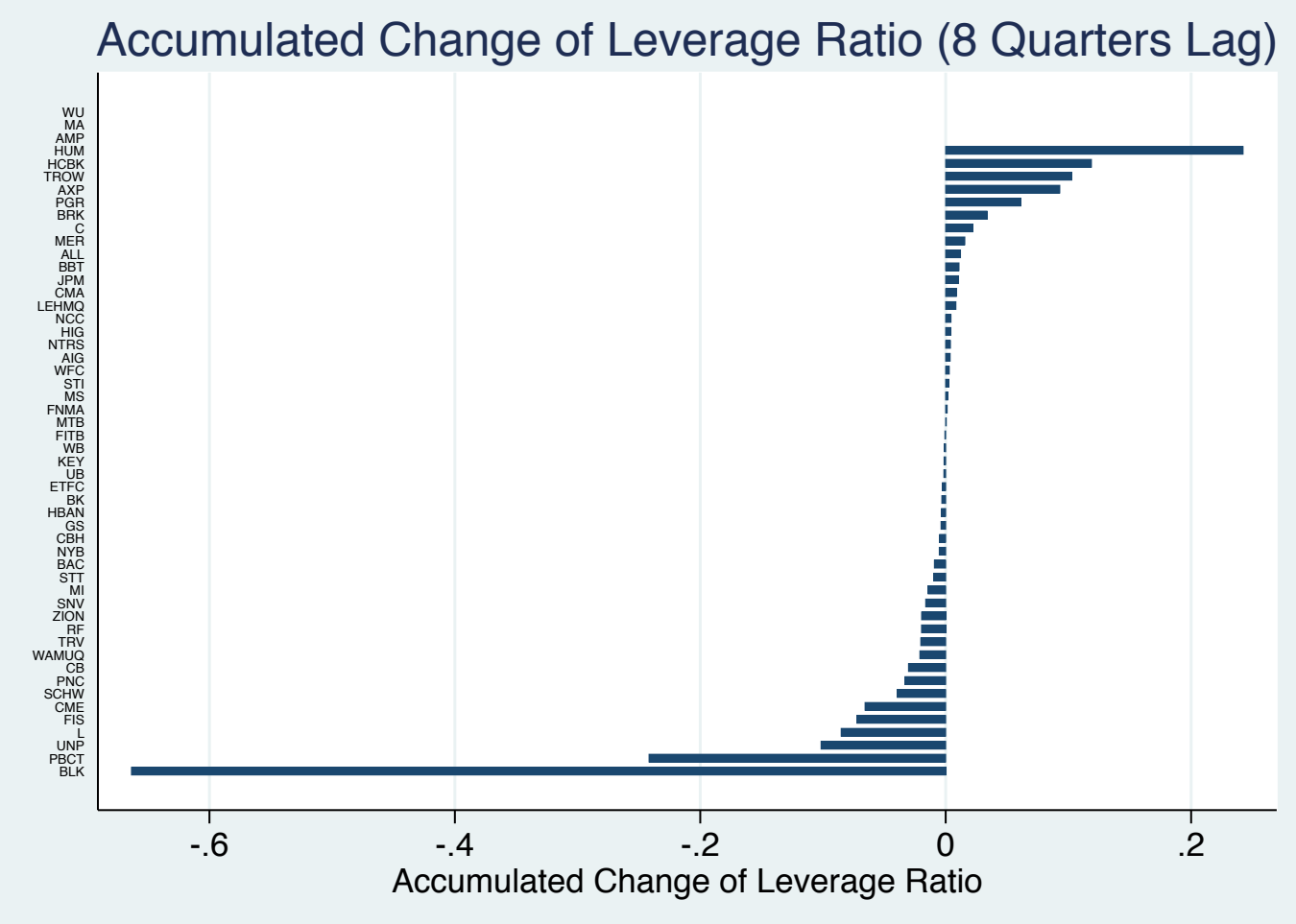




\section{CURRENT RATIO (CR)}

In essence, a current ratio compares firms' current assets relative to its current liabilities. The current ratio shows firms' ability to pay back short-term liabilities which require payment within one year using short-term assets (cash, cash equivalent, and short-term investment). The higher the current ratio, the more capable the company is to meet its obligations. However, even though a ratio under one does not necessarily mean that a company will go bankrupt due to the many ways that a company can access capital via financing, it does suggest that a company would be unable to pay off its obligation and shows that it is not in good financial health.

Scholars have used different measures of liquidity. For example, Adrian and Brunnermeier (2011) use the balance between assets and liability as a measure of each firm's ability to pay their obligations, while other scholars use measures such as interest coverage ratio or acid cash ratio. In this dissertation, liquidity is computed as the total current assets scaled by total current liabilities as shown below.

$\mathrm{CR}=($ Current Asset) $/$ (Current Liability)

Figure 3.6a shows the firms' average levels of current ratio over eight quarters pre-crisis event in 2007q3. However, the average level's method shows that 'firms went bankrupt' distributed all over, while the use of accumulative change of current ratio method shows that firms went bankrupt grouped in the negative side as shown in Figure 3.6b. 
Figure 3.6a: Firms' average levels of current ratio.

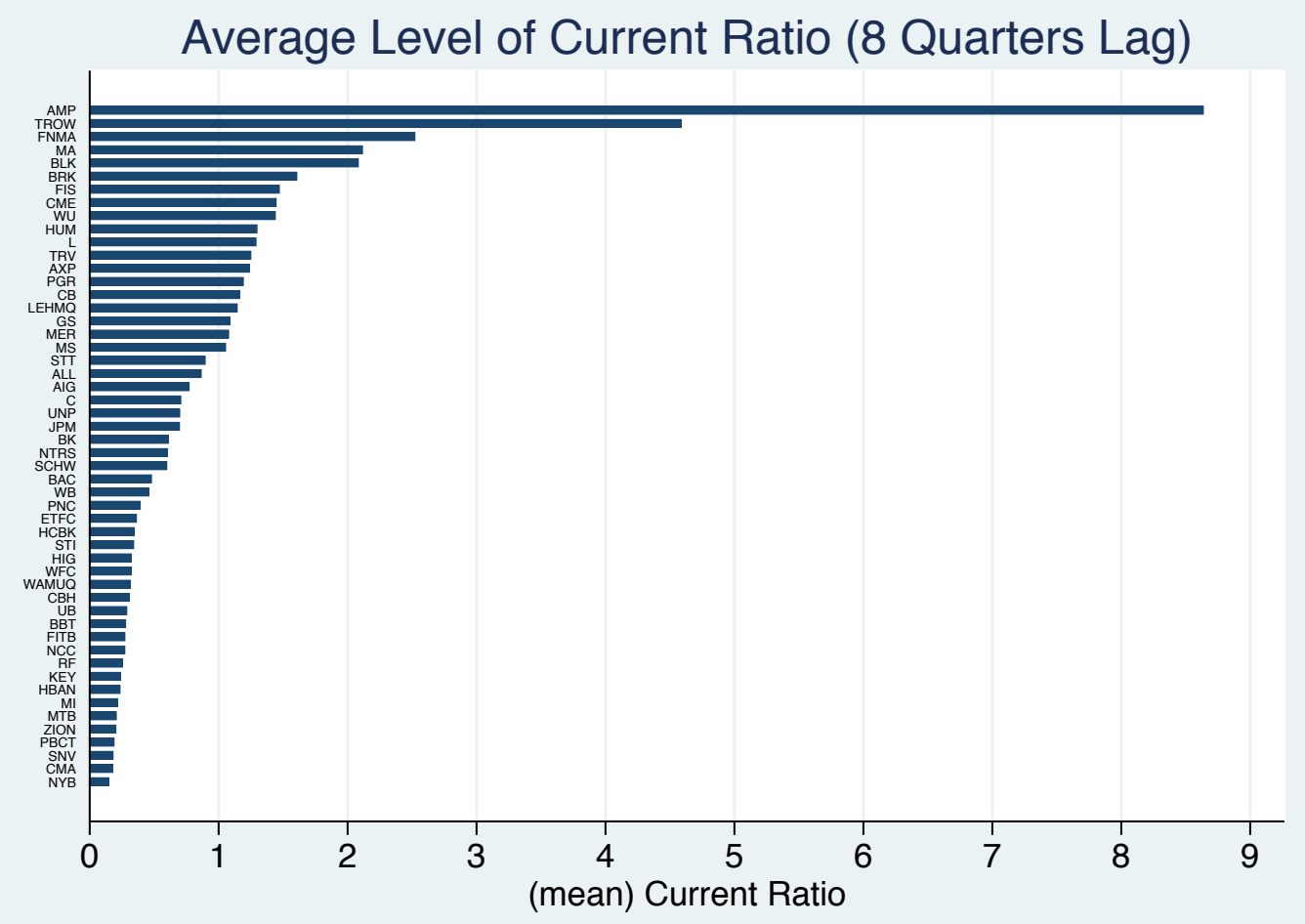

Figure 3.6b: Firm's accumulated rate of change of current ratio.

Accumulated Rate of Change of Current Ratio (8 Quarters Lag)

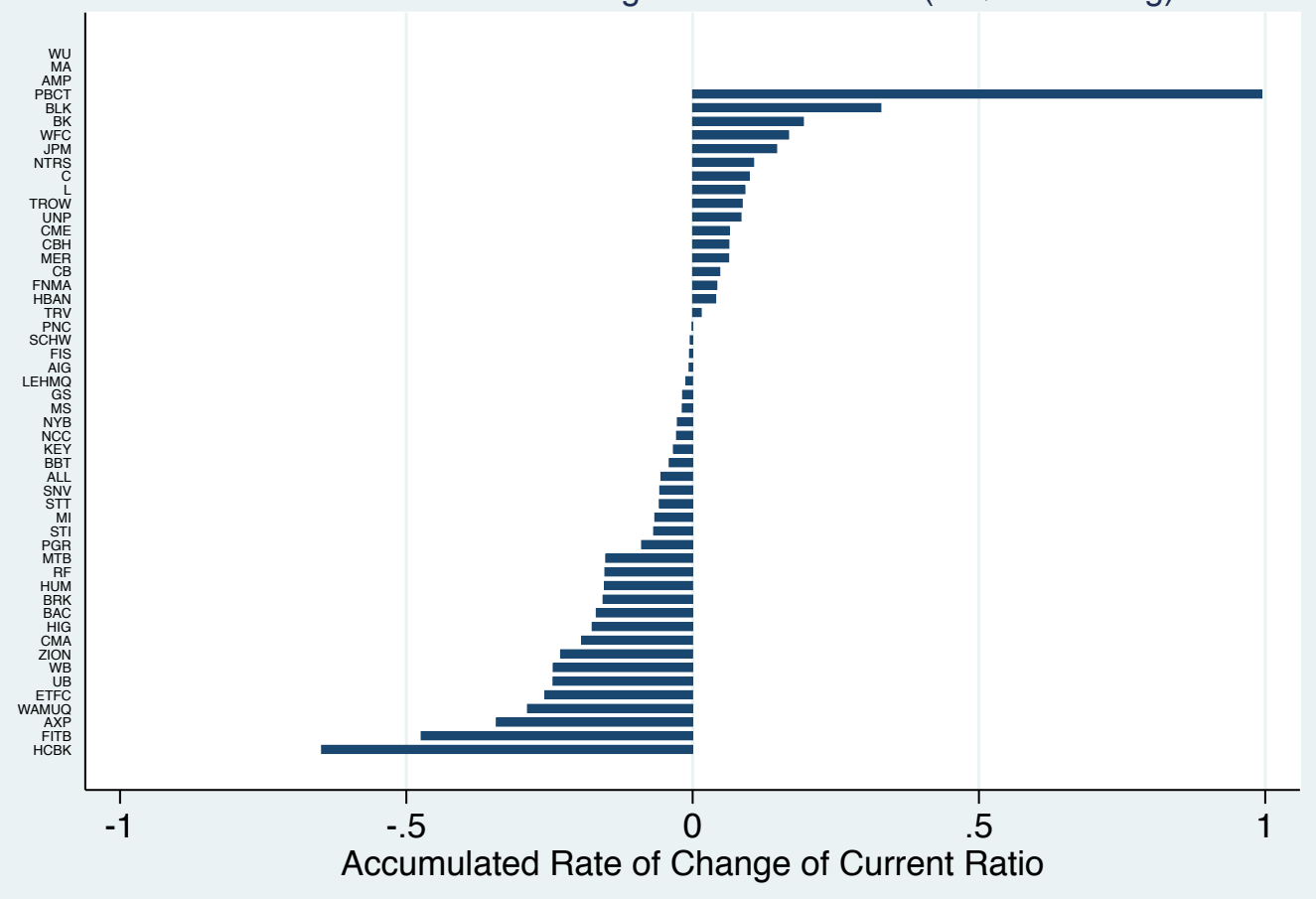




\section{ASSET TURNOVER RATIO (ATR)}

Asset turnover ratio measures how efficiently a firm is at using its assets to generate revenues regardless of size. The higher the ratio, the more efficient the firm is. Asset turnover ratio also resolves a major shortcoming of return on equity (ROE) as the latter ratio does not tell if a company has excessive debt or uses debt to drive returns. However, asset turnover ratio does include liabilities like debt in their assets and therefore, the lower the debt, the higher the ATR is.

ATR $=($ Revenue $) /($ Average Asset $)$

Figure 3.7a shows that most of 'firms went bankrupt' or 'severely damaged by the crisis' positioned at lower ratios and more than 35 financial firms have the average level of asset turnover ratio below 0.05 which means that a firm can generate only 0.05 from using each unit of asset. However, the average level's method shows that 'firms went bankrupt' distributed at the bottom of the previous figure all over, while the use of accumulative change of asset turnover ratio method shows that 'firms severely damaged by the crisis' distributed on both directions as shown in Figure 3.7b. 
Figure 3.7a: Firms' average levels of asset turnover ratio.

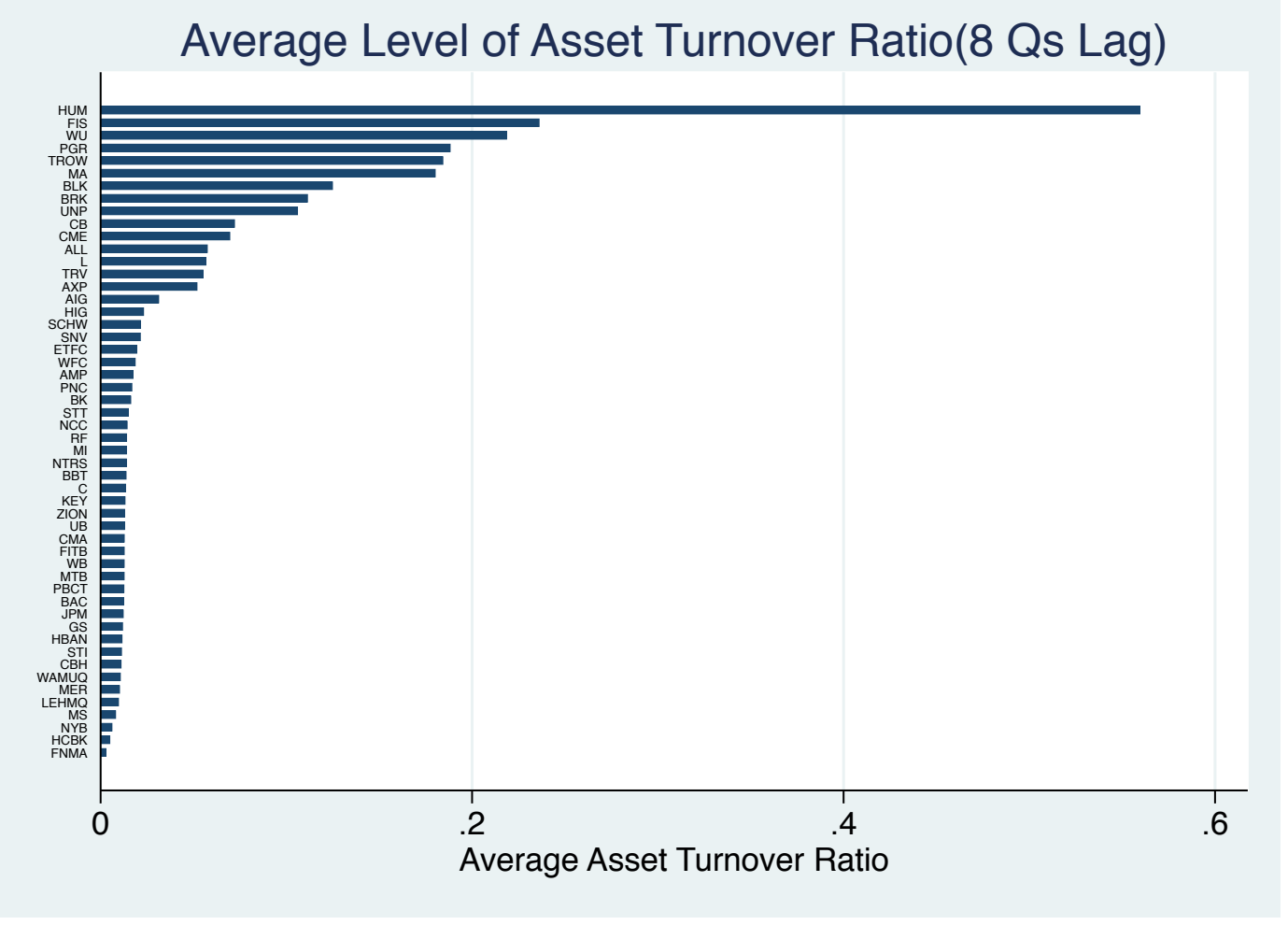

Figure 3.7b: Firm's accumulated rate of change of asset turnover ratio.

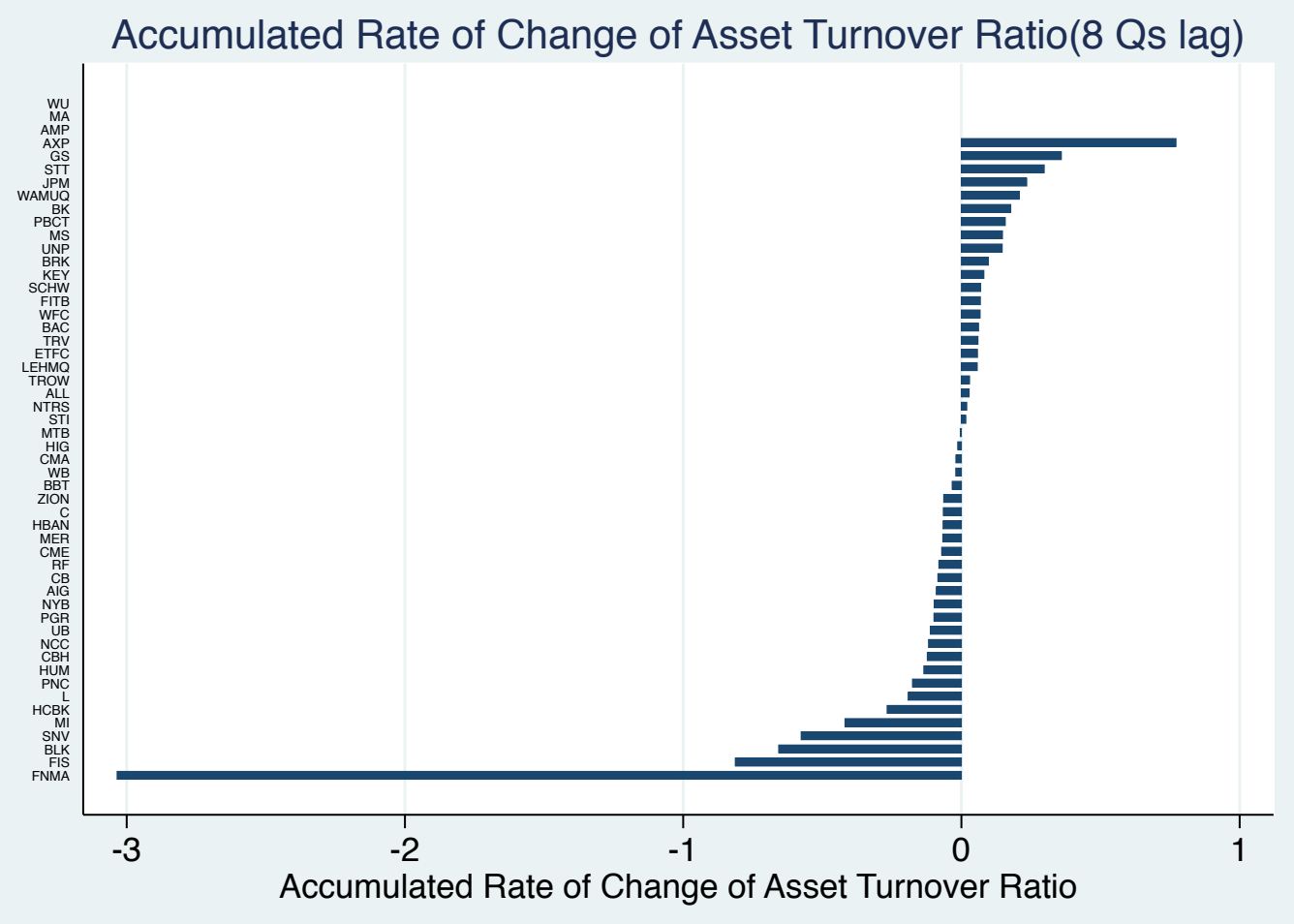




\section{RETURN ON ASSET (ROA)}

Return on assets ratio measures how efficiently a company can generate profit from its assets regardless of its size. The higher the ratio, the more efficient the firm and better performance it has. Also, return on assets resolves the weakening of return on equity as does asset turnover ratio.

$\mathrm{ROA}=($ Net Income $) /($ Average Asset $)$

Figure 3.8a shows the firms' average levels of return on asset ratio over eight quarters pre-crisis event in $2007 q 3$, while Figure $3.8 \mathrm{~b}$ shows the firms' accumulative change of return on asset ratio.

Figure 3.8a: Firms' average levels of return on asset ratio.

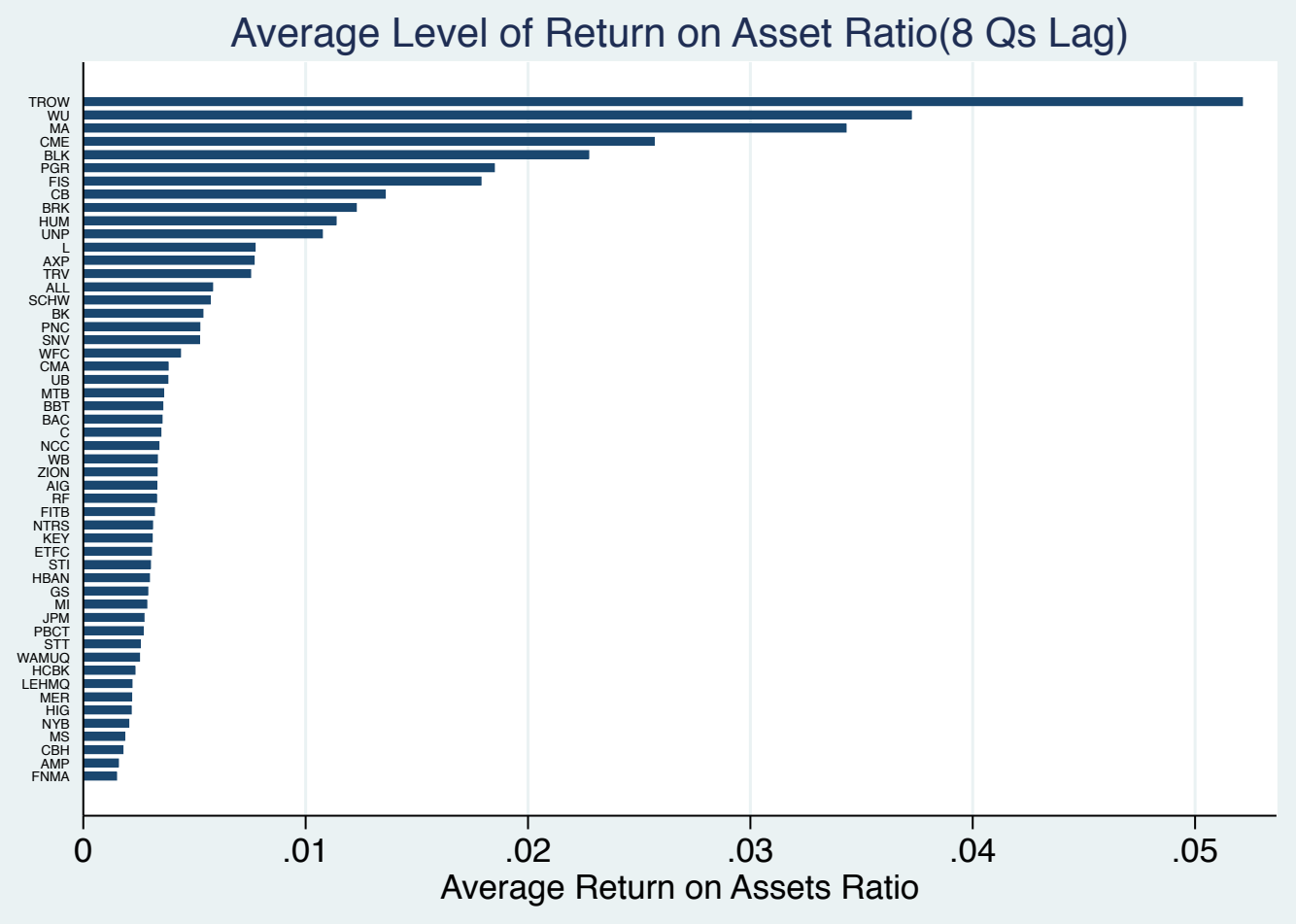


Figure 3.8b: Firm's accumulated rate of change of return on asset ratio.

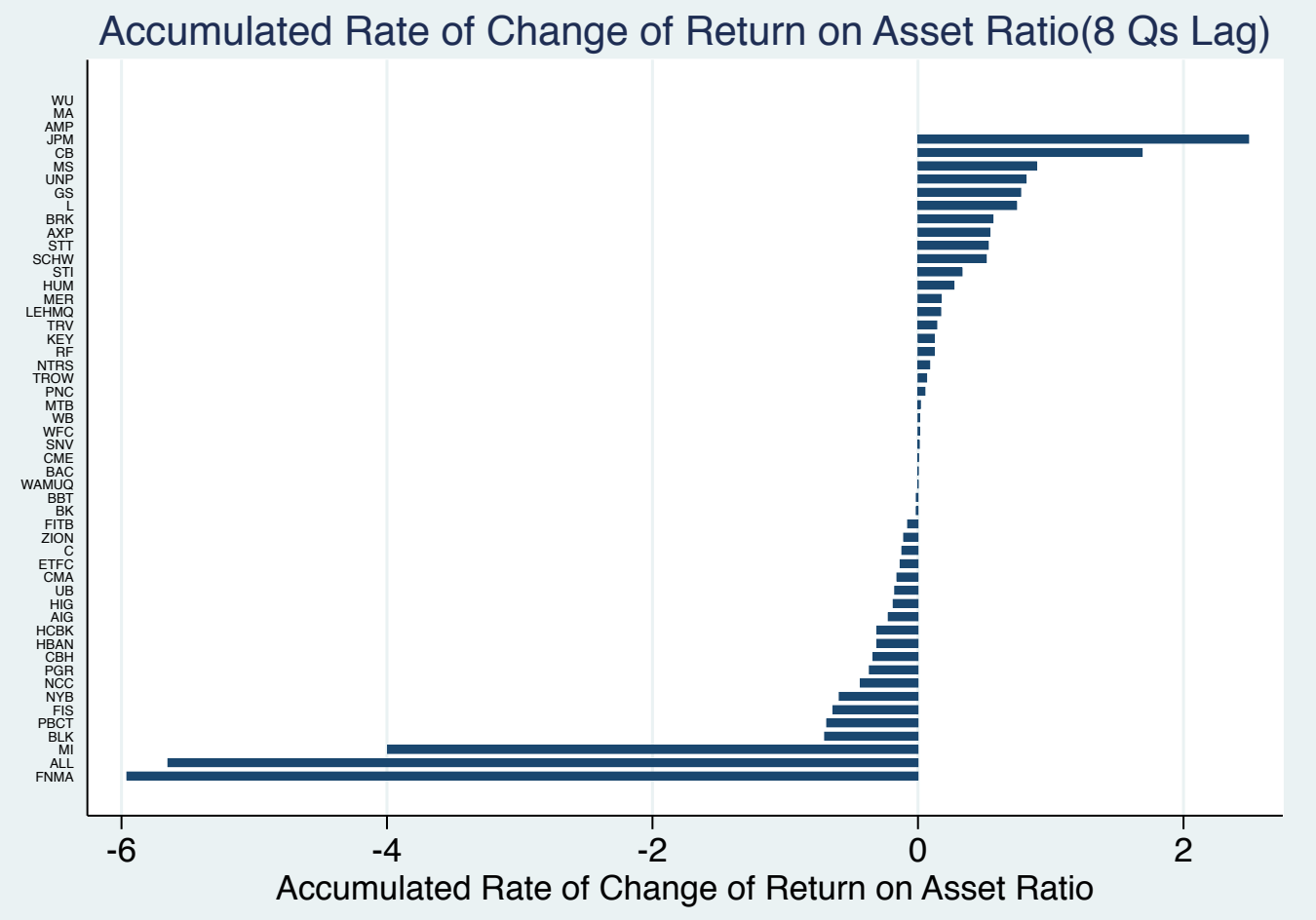

\section{OPERATING CASH FLOW RATIO (OCF)}

Positive cash flow (or liquidity) is the key to survival because it gives firms the ability to pay creditors. With positive cash flow, opportunities can be taken and firms can keep the entity from going into bankruptcy, buy back stock, pay out dividends, and make acquisitions (to further growth). For future growth and the ability to meet a firm's obligations, the firm must be able to generate cash flow from its operations. OCF ratio shows how efficient a firm is at generating cash flow from operation by the usage of asset. Conversely, negative cash flow from operations cause an increasing drain on cash rather than providing cash. This necessitates an increased use of external cash flow that would increase their expenses. Figure $3.9 a$ shows the average level of 
operating cash ratio and Figure $3.9 \mathrm{~b}$ shows the accumulative change of operating cash flow ratio.

OCF $=$ (Operating Cash Flow) $/$ (Average Asset)

\section{FINANCING CASH FLOW RATIO (FCF)}

Positive financing cash flow ratio shows to what extent a firm depends on rising debt or issuing more stocks relative to the average asset over a certain period. On the other hand, negative financing cash flow ratio shows to what extent a firm pays back its debt or buys back its shares or paying dividends. Figure 3.10 shows the firms' average levels of financing cash flow ratio.

$\mathrm{FCF}=($ Financing Cash Flow $) /($ Average Asset $)$

\section{INVESTING CASH FLOW RATIO (ICF)}

Positive investing cash flow ratio shows to what extent a firm depends on generating cash by selling its assets. On the other hand, negative investing cash flow ratio shows to what extent a firm invests by buying new assets. In general, a firm that generates cash flows only by selling its assets (obtaining cash flow from investing activities) or by issuing more shares debts (obtaining cash flows from financing activities) cannot keep that up for very long. Figure 3.11 shows the firms' average levels of investing cash flow ratio.

$\mathrm{ICF}=($ Investing Cash Flow) $/$ (Average Asset) 
Figure 3.9a: Firms' average levels of operating cash flow ratio.

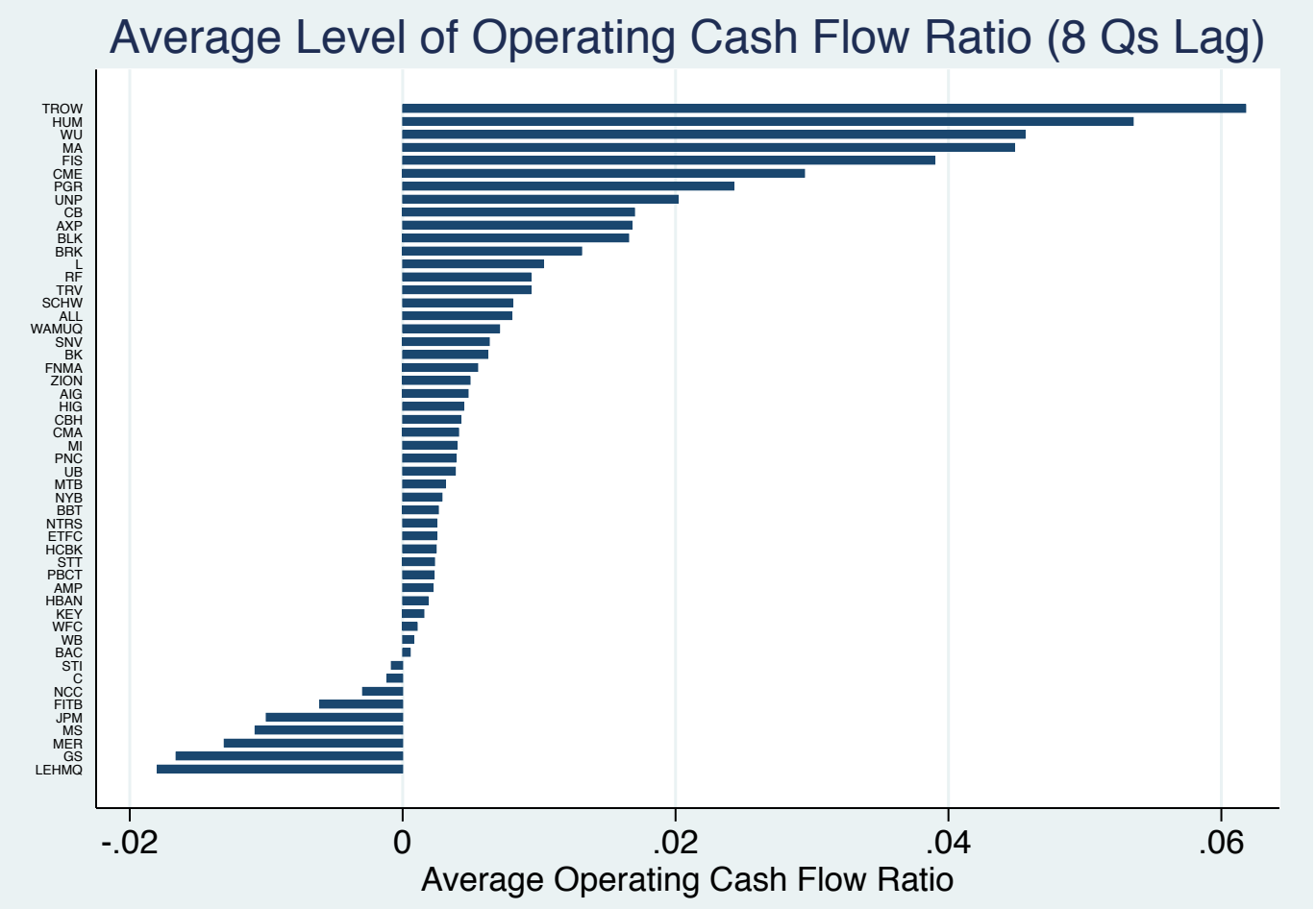

Figure 3.9b: Firm's accumulated rate of change of operating cash flow ratio.

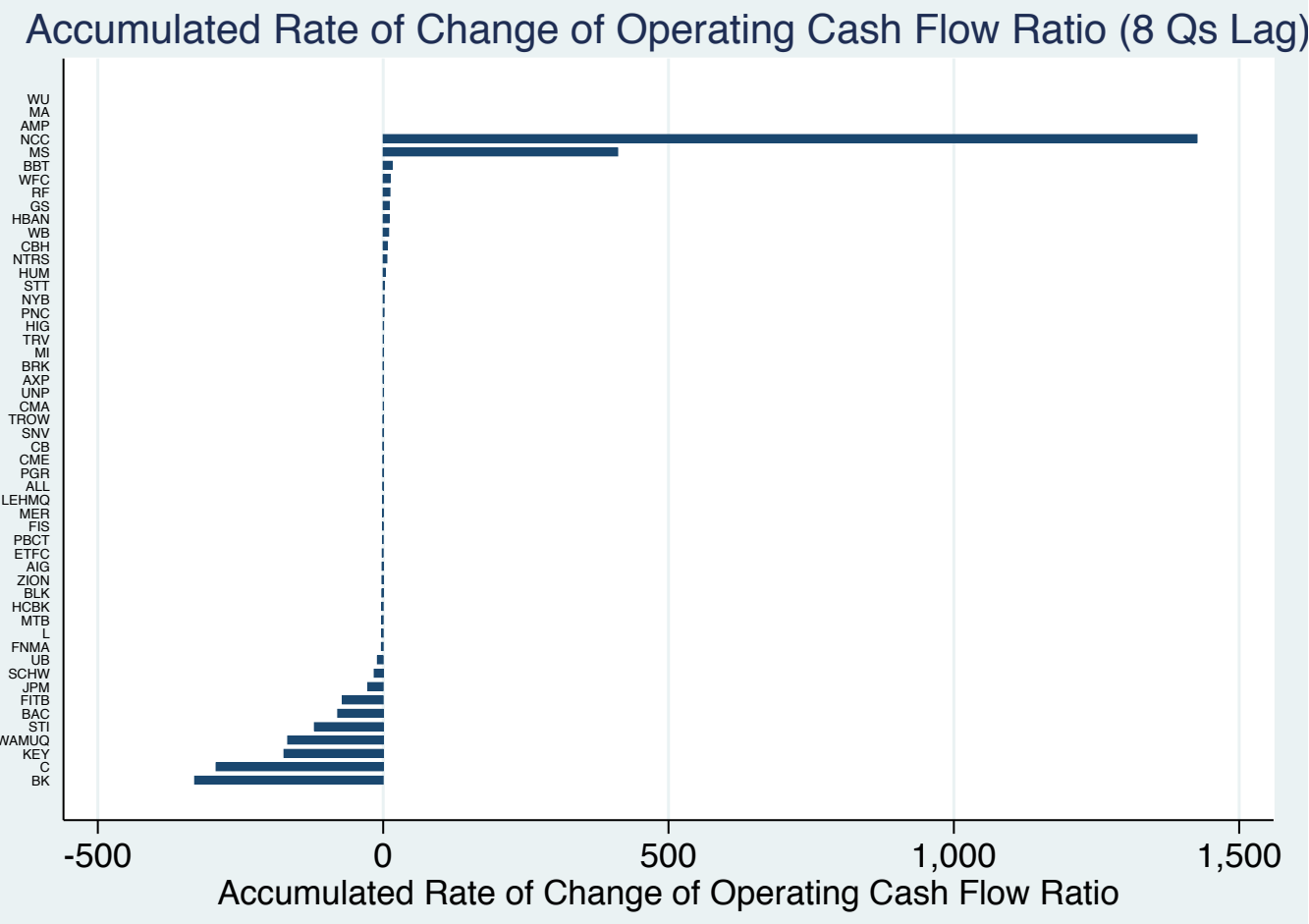


Figure 3.10: Firms' average levels of financing cash flow ratio.

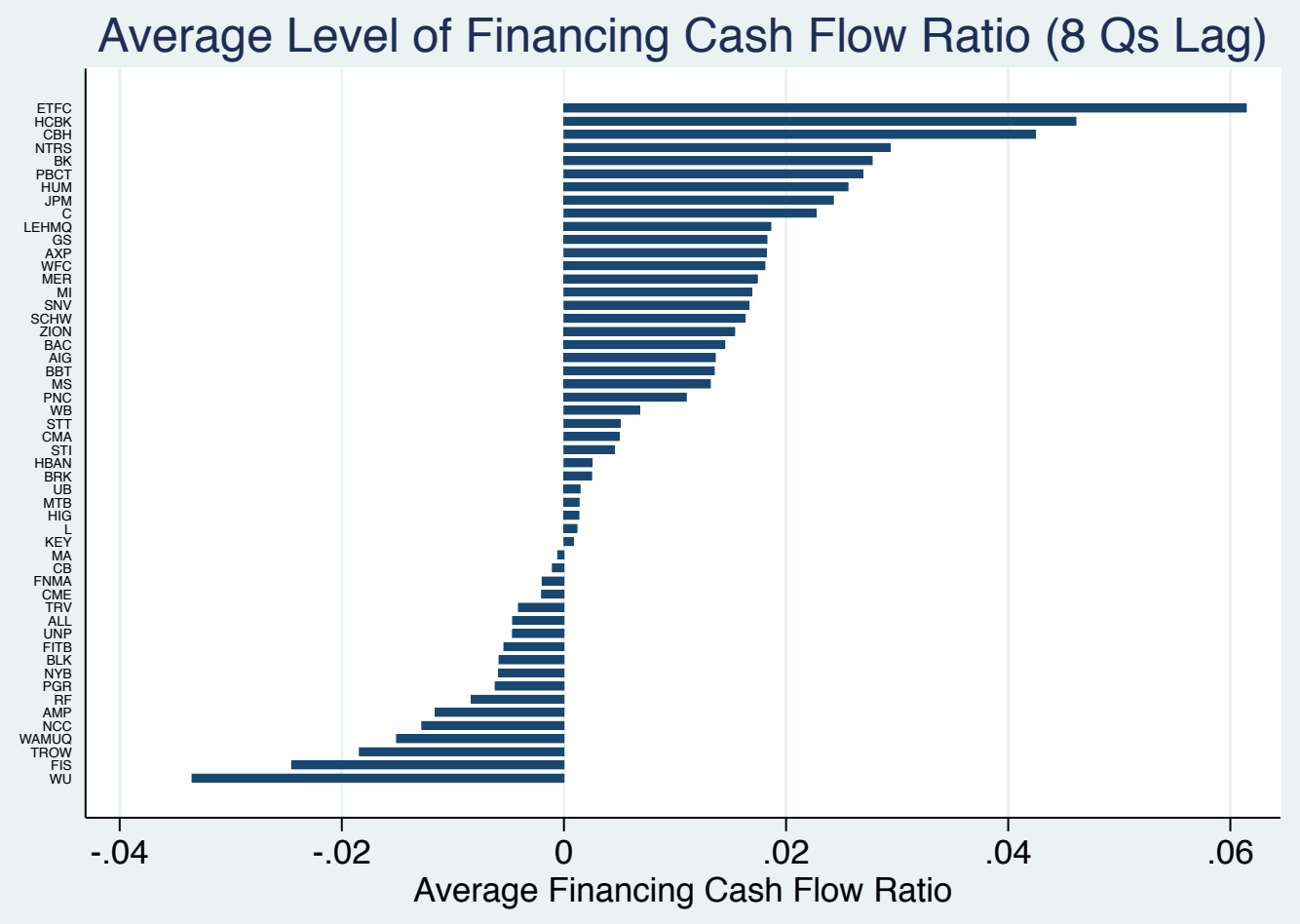

Figure 3.11: Firms' average levels of investing cash flow ratio.

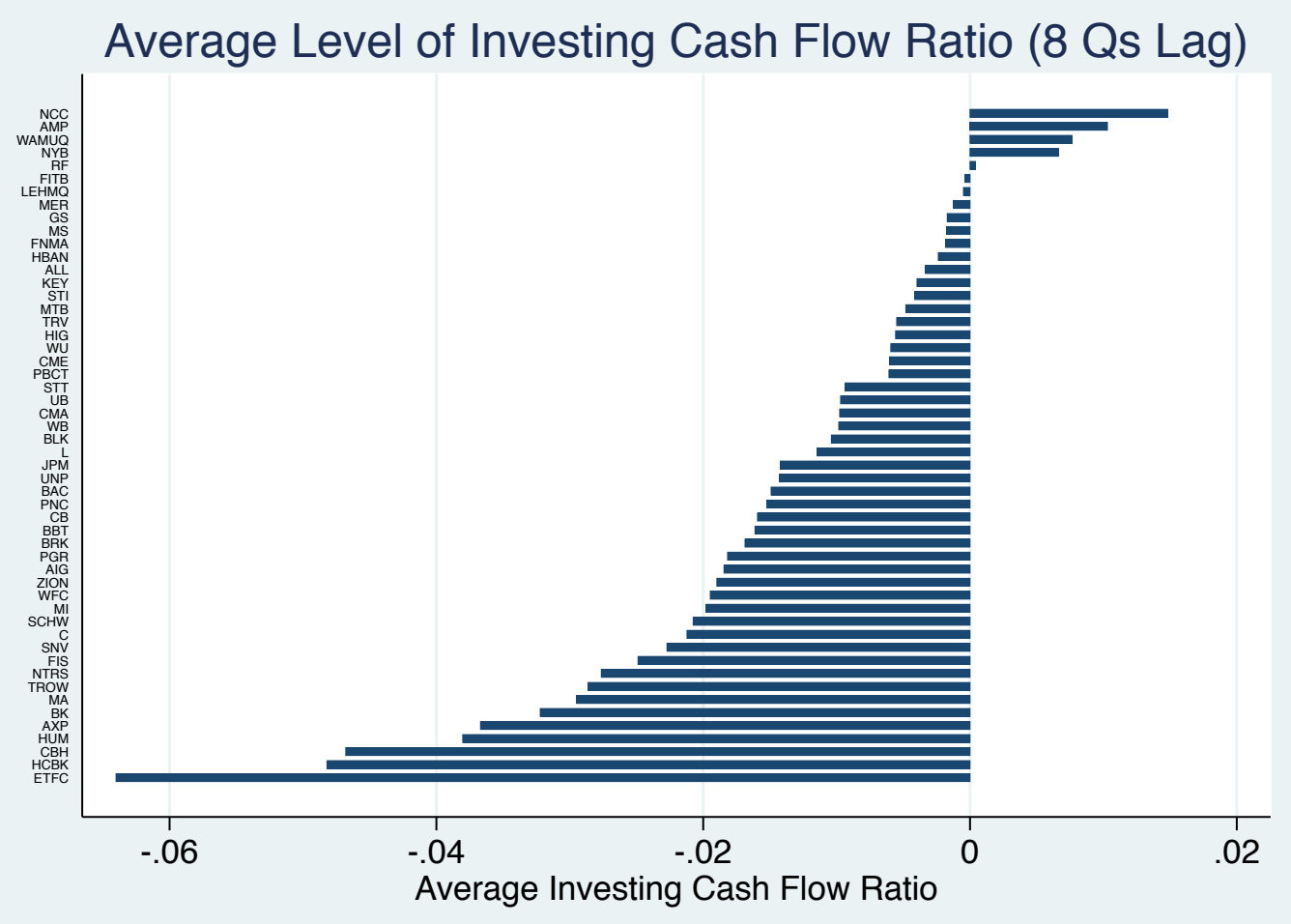




\section{FIRM SIZE (A)}

A firm's size as presented via taking the natural log of total book-valued assets has a major role in most of the literature to measure a bank's contribution to the systemic crisis. Many scholars view larger banks as more connected to other financial firms than smaller banks. Such high interconnectedness among large banks generated the term "Too Big to Fail" (TBTF). One side finds that larger banks have the ability to increase their profits and as a result, also have the ability to diversity their risks ending up minimizing those banks' contribution to such systemic risk. ${ }^{1}$ The other side finds large banks implied insurance via TBTF policy which allows those banks' managers to take high investment risks in order to gain more profits. This in turn lead into those banks making a higher contribution to systemic risk. ${ }^{2}$ Therefore, the inclusion of this variable allows examining the importance of the firm's size to predict the stock market effects of a systemic crisis. Figure 3.12 shows the firms' sizes starting from the largest.

$A=\log ($ Total Asset in Book Value)

\footnotetext{
${ }^{1}$ See Diamond (1984), Freixas and Rochet (2008), Matutes and Vives (2000), and Boyd et al (2004).

${ }^{2}$ See Beck, Demirguc-Kunt, and Levine (2006) and Brunnermeire et al. (2012).
} 
Figure 3.12: Firms' natural log of total book-valued assets (size).

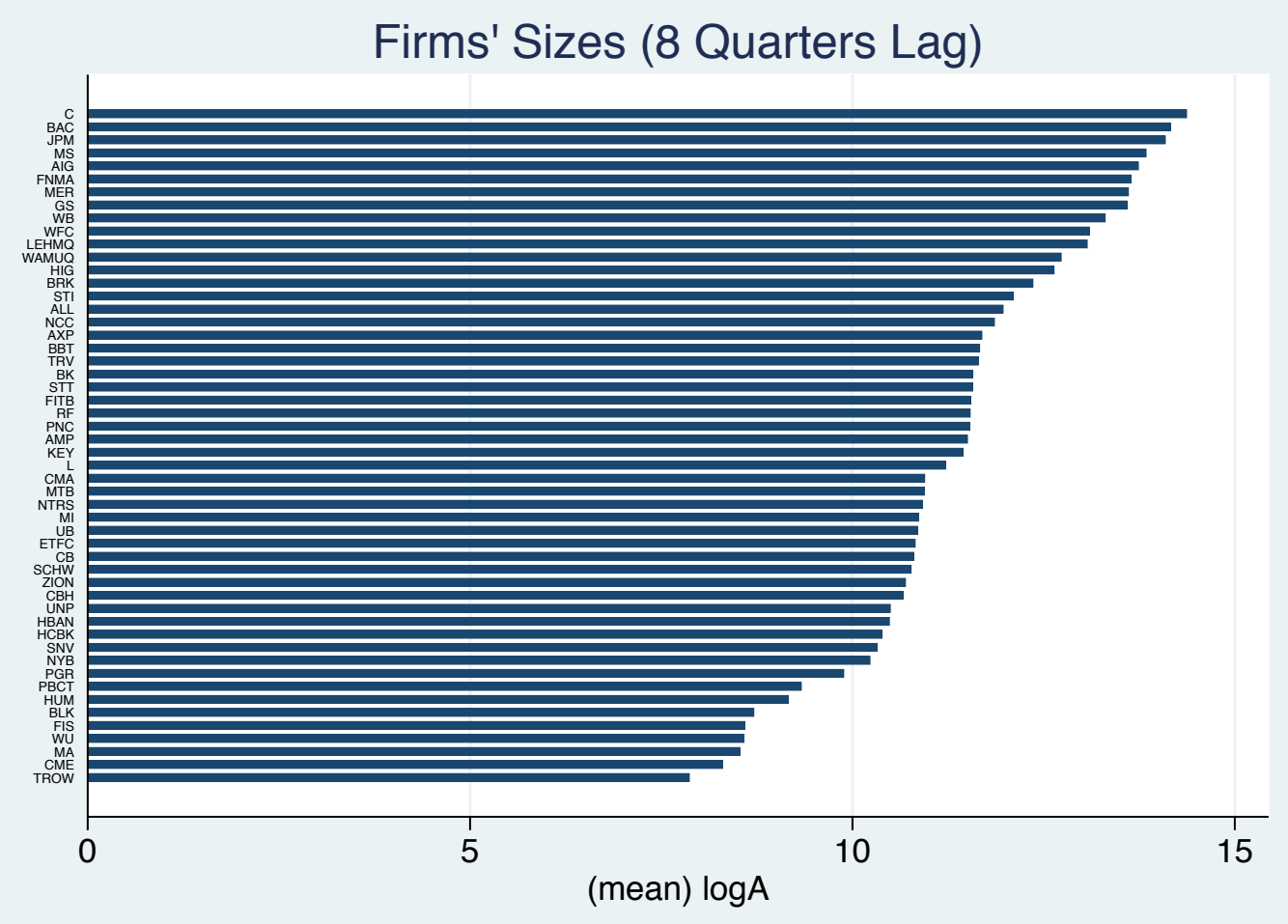

\section{SHORT- AND LONG-TERM INVESTMENT ASSETS RATIO (A2a)}

The fraction of total book-valued assets, illustrated by the short- and long-term investment assets scaled by total assets, indicates to what extent each firm heavily invests in new assets or sells current assets. This implies growth when it increases or declines when it shrinks. Moreover, these types of assets are the main assets to be converted into cash when asset or market liquidity risk is high and cash is needed most to meet their obligations. Thus, this variable would be used to evaluate such risk and its consequences such as fire-sale spirals. On the other hand, the increase of this ratio means that the bank is exposed to higher counterparty default which causes that bank 
to contribute more to systemic risk. Figure 3.13a shows the average level of short- and long-term investment assets ratio and Figure $3.13 \mathrm{~b}$ shows the accumulative change of short- and long-term investment assets ratio.

$\mathrm{A} 2 \mathrm{a}=($ Short \& Long Term Investment Asset $) /($ Total Asset $)$

Figure 3.13a: Firms' average levels of short- \& long-term investment assets ratio.

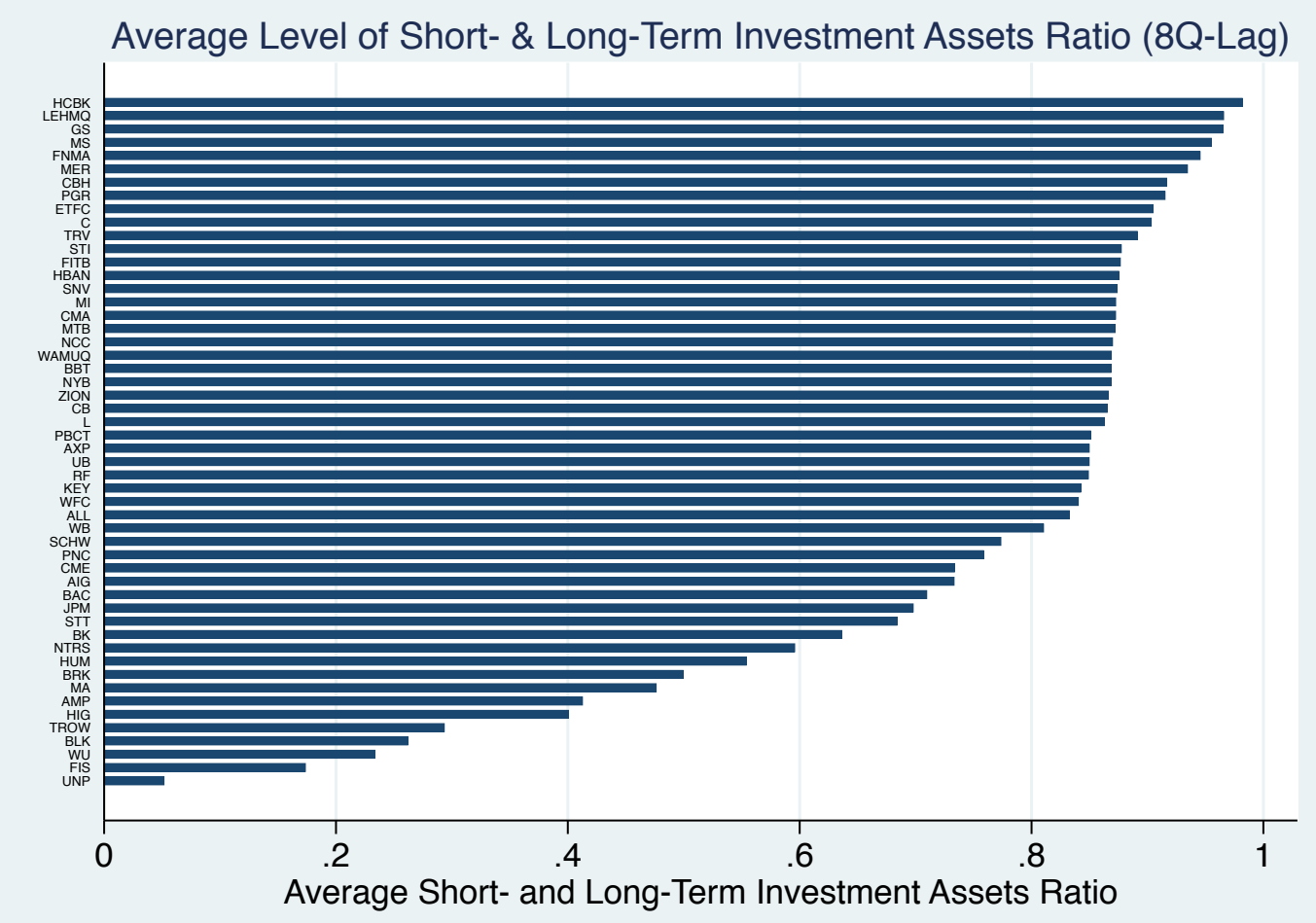


Figure 3.13b: Firms' accumulated rate of change of short- \& long-term investment assets ratio.

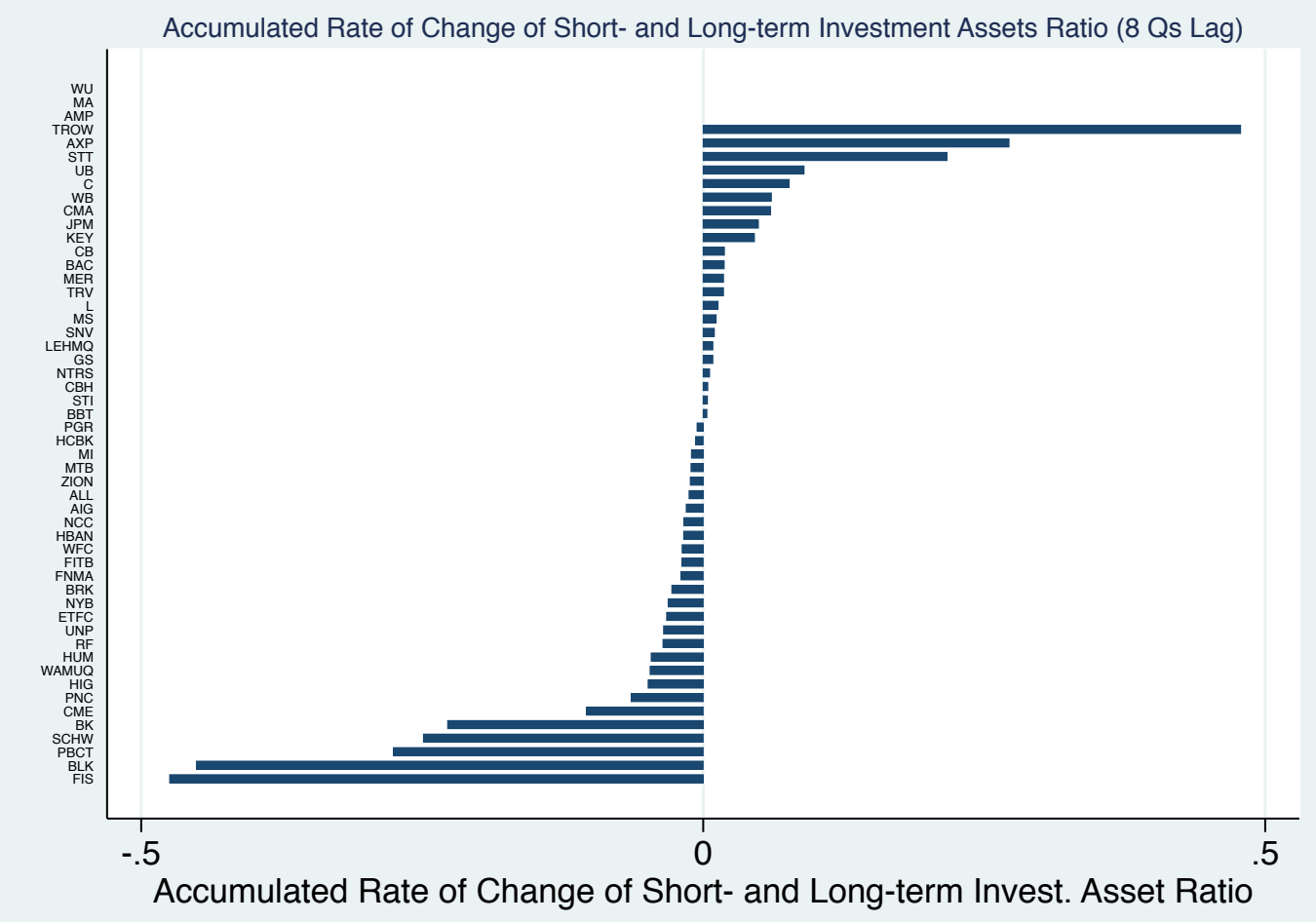

\subsection{DATA COLLECTION PRECEDURES AND ANALYSIS}

\subsubsection{INSTRUMENTATION}

Financial statements cover four different types of statements. First, a statement of balance provides data on a firm's assets, liabilities, and equity at any given point in time. Second, a statement of profit and loss provides data on a company's revenues, expenses, and net profits over a period of time. Third, a statement of changes in equity provides data on firm's equity throughout the reporting period. Finally, a statement of cash flow provides data on a firm's cash flow activities-operating, investing and financing activities. Therefore, the objective of these statements is to provide reliable data about firms to a wide range of users allowing users to make proper economic 
decisions regarding their expectations about the future of the financial positions, performances, and ability of an individual firm to generate profit in the future.

In the U.S., all financial institutions need to report to the Securities and Exchange Commission (SEC) on a quarterly and annual basis and are seized particularly in the post-Enron era. Therefore, CEOs are personally liable for the accuracy of these reports. For example, the former CEO "Bernie Ebbers" of World.Com was sentenced for 25 years behind bars for overstating revenues over a period of many years.

\subsubsection{DATA PROBLEMS}

One of the problems faced in this analysis is multicolinearity among independent variables (see Table 3.4 in Appendix C). Many researchers attempt to drop one or more independent variables when this issue arises to overcome biased estimates. Consequently, we would lose information relevant to variables which would result in a similar situation of biased estimates. Also, methods to solve problems with multicolinearity can create more serious problems, and a variance inflation factor (VIF) of 40 or more does not by itself lower the results of the regression analyses (O'Brien, 2007).

When a fractional polynomials model is generated, it causes a special type of multicolinearity that typically does not result in reduction of the predictive power or the reliability of models as a whole and it only affects predictions regarding individual predictor. Therefore, the rise of multicolinearity does not affect the effectiveness of the fitted model when conducted with new data, which follows the same pattern as the old data (Gujarati, 2002). 


\subsubsection{DESCRIPTIVE ANALYSIS}

Tables 3.5 in Appendix C shows the descriptive statistics of both dependent variable that have been used in this study and shows that both outcomes are normally distributed. Table 3.6 in Appendix C summarizes the distribution of independent variables calculated by the method of average levels, while the other variables calculated by the accumulative change are shown in Table 3.7 in the same Appendix. We use different logarithmic functions to transform highly skewed data particularly when conducting the analysis based on Structural Equation Modeling in order to make the data more symmetrical and normally distributed. Highly skewed variables on the right are associated with average level of asset turnover, return on asset, and current ratios, whereas highly skewed variables on the left are associated with financial leverage and short- and long-term investment assets. 


\section{EMPERICAL ANALYSIS BASED ON STRUCTURAL EQUATION MODELING}

\subsection{ANALYSIS AND PROCESSING}

Structural Equation Modeling (SEM) is a very broad term that includes many different types of analyses. We use a type of structural equation model called 'path analysis' that allows a variable to be a dependent variable in one analysis and an independent variable in another called a mediating' or 'intervening' variable. Path analysis uses the general linear modeling (GLM) approach to estimate non-recursive models, models with measurement error, and models with latent (unobserved) variables.

A series of models was created to examine whether or not our hypothetical view about the relationships between variables was adequate to explain the data. In the final part of this section, we will test the best fit model over varying lag periods. The models are designed in this study to further investigate the expected interactions between financial leverage ratio and other independent variables and to test it against other models which could serve as alternative explanations for the data. The models are hierarchical which means that the first model is a baseline model. Elements are then added and goodness of fit indices are examined to test whether each model is an acceptable fit. The fit indices that will be examined include the Comparative Fit Index (CFI), which should carry a value that is close to one and not lower than .93 for an acceptable fit. The Tucker Lewis Index (TLI) will also be used which also be close to one, not lower than 0.90 for an acceptable fit, and higher than 0.95 for a good fit 
(Bentler, 1990). ${ }^{1}$ The root mean squared error of approximation (RMSEA) will be also examined and should have a value that is lower than .08 for an acceptable fit and a value that is less than .05 for a good fit. The standardized root mean squared residual (SRMR) value should be less than .05 , and the chi square and associated $p$-value should be non-significant meaning that the data estimates created from the model are not significantly different than the observed data. ${ }^{2}$

The first set of models (SEM1) examines the effect of both assets turnover ratio and time-weighted rate of change of current ratio upon both average level and accumulated rate of change of financial leverage ratios in order to predict changes in stock market prices (\%Y1 and \%Y2) over three different lags. The second set of models (SEM2) tests the same relationships as those in the first set (SEM1) but adding another predictor variable, the natural $\log$ of firm's asset $(\log A)$. The third set of models (SEM3) tests the same relationships as in the first set (SEM1) but adding a new mediator variable to the model, the time-weighted rate of change of short- and long-term investment asset ratio to mediate the effect of leverage ratio. These hypothetical views are shown in Figures 4.1, 4.2, and 4.3 in Appendix D respectively.

\subsection{MODEL COMPARISONS}

As mentioned previously, these three sets of models (SEM1, SEM2, and SEM3) are created to test our hypothetical view for the relationships between the independent variables and the dependent variables over varying lags to test whether it fits the data.

\footnotetext{
${ }^{1}$ See Bentler (1990) for more details.

${ }^{2}$ See Browne and Cudeck (1993) for more details.
} 
The first set of models (SEM1) shows poor results according to the criteria used to predict $\mathrm{Y}$ 1, but showed an acceptable fit when predicting $\mathrm{Y} 2$ over 4 and 8 quarters lag only. The second hypothetical view represented in SEM2 showed an improvement relative to SEM1. However, it showed the same results regarding the second outcome Y2 over 4 and 8 quarters lag as found in SEM1. It shows an additional good-fit model predicting the first outcome Y1 over 8 quarters lag. Finally, the SEM3 showed the bestfit set among all the models. However, it showed the same results regarding the second outcome Y2 as previously mention in SEM1 and SEM2. It shows a good fit result for another two models predicting the first outcome $\mathrm{Y} 1$ over 4 and 8 quarters lag. While the result for the model run over 4 quarters lag shows an acceptable fit (RMSEA=0.080), the model run over 8 quarters lag shows a good fit results for the data. Therefore, the model from the set SEM3 which run over 8 quarters lag to predict the first outcome Y1 is the best-fit model among all models in all sets as it meets all criteria $x^{2}=8.969$, the associated $p$-value is equal to 0.345, RMSEA $=0.048$ which is below the 0.05 level, and the probability of getting RMSEA significant is 0.441 . In addition, it has the closest values to the value of one for $\mathrm{CFI}=0.987$ and $\mathrm{TLI}=0.978$, and the coefficient of determination $C D=0.677$. The fit indices results regarding the three sets of models (SEM1, SEM2, and SEM3) are shown in Table 4.1, 4.2, and 4.3 in Appendix D respectively. In addition, the standardized coefficients results for the models (SEM1-Y1, SEM1-Y2, SEM2-Y1, SEM2-Y2, SEM3-Y1, and SEM3-Y2) are shown in Tables 4.4, 4.5, 4.6, 4.7, 4.8, and 4.9 in Appendix D respectively.

We find that model SEM3-8Q to be the best-fit model according to the aforementioned criteria. Therefore, a test for its plausibility and expected relationships 
between the independent and dependent variables needs to take a place. First, there are variables that have direct effects on the outcome such as asset turn over, accumulated rate of change of current ratio, and accumulated rate of change of shortand long-term investment assets, while variables such as average level of leverage and its accumulated rate of change have indirect effect on the outcome. Table 4.8 shows the standardized coefficients results regarding to this model (SEM3-8Q) which predicts the first outcome $\mathrm{Y} 1$ based on the third hypothetical view over an eight quarters lag. For example, the coefficient -0.036 shows the goodness of the fit for the best possible linear relationship between $\left(\mathrm{ATR}^{-0.5}\right)$ and $(\mathrm{Y} 1)$ when holding other variables constant. This is a significant negative relationship at a level of $\alpha=0.01$. Thus, if asset turnover $(\mathrm{ATR})$ increases, then $\left(\mathrm{ATR}^{-0.5}\right)$ will decrease and $(\mathrm{Y} 1)$ will increase as well which states a positive relationship between ATR and $\mathrm{Y} 1$ similar to what we expected. This means that there would be a -0.036 unit change in $\mathrm{Y} 1$ per one standard deviation change in $\left(\mathrm{ATR}^{-0.5}\right)$. In other words, if the inverse square root of asset turnover ratio increases by one standard deviation (mean level=7.336 and $1 S D=3.373$ ), the asset turnover ratio will decrease by 53.07 percent from 0.185 to 0.0087 , and a more than average decline in stock market price as well by 11.02 percent. But if the inverse square root of asset turnover ratio decreases by one standard deviation, the asset turnover ratio will rise by 242.6 percent from 0.0185 to 0.0636 , and a less than average decline in stock price by 11.02 percent as well. This illustrates how sensitive the change in stock price to a firm's inability to generate revenue from its assets in an efficient way. This is the economic interpretation of the existence of the inverse square root of asset turnover ratio. Figure 
4.4 in Appendix $D$ shows the relationship between asset turnover ratio and predicted change of stock market price.

The relationship between the accumulated rate of change in short- and long-term assets (rrA2) and outcome (Y1) was not significant. A negative sign that shows an increase in this fraction of asset over a period of many years has a negative impact on the change in stock price. The third direct impact on the outcome comes from the accumulated rate of change of current ratio ( $r \mathrm{rCR})$. It shows a significant positive relationship at the level of 0.05 between the ratio of current asset to current liability with (Y1), and the coefficient of 0.30 shows the goodness of the fit for the best possible linear relationship between the two variables. When current asset grows faster than current liability over many years, the model predicts a less decline than average in stock market price. For example, holding all other ratios unchanged, if this ratio ( $\mathrm{rrCR}$ ) increases or decreases by one standard deviation from mean level from -0.037 to 0.19 or -0.264 (mean level $=-0.0374$ and $1 \mathrm{SD}=0.227$ ), the model predicts a less or more decline than average in stock price by the same percent (i.e. 9.18 percent) respectively. In short, if a firm's current asset (cash or liquid asset that can be transferred into cash) grows at a rate faster than that of its current liability (short-term debts), the model predicts a lower decline than average in stock market price. In Appendix D, Figure 4.5 shows the relationship between the growth of short- and long-term investment assets and predicted change in stock market price, and Figure 4.6 shows the relationship between the growth of current ratios and predicted change in stock market price.

When examining the predictor variables that have indirect effects, cubed financial leverage ratio has a positive significant relationship with the inverse square root of ATR 
at $\alpha=0.001$ level of significance. The coefficient value 0.62 shows the goodness of fit for the best possible linear relationship between $\left(L^{3}\right)$ and $\left(\mathrm{ATR}^{-0.5}\right)$. A small increase in financial leverage ratio would be amplified by the cubed function to reflect its positive significant effect on $\left(\mathrm{ATR}^{-0.5}\right)$ and its indirect negative effect on $(\mathrm{Y} 1)$ through $\left(\mathrm{ATR}^{-0.5}\right)$. If the cubed average level of leverage ratio over two years increases by one standard deviation, it would cause $\left(\mathrm{ATR}^{0.5}\right)$ to increase by 0.62 per unit changed. In addition, to calculate the indirect effect of the predictor variable $\left(\mathrm{L}^{3}\right)$ on the outcome $(\mathrm{Y} 1)$, we need to multiply the two path coefficients $\left(0.62^{*}-0.036\right)$ to get $(-0.223)$. Thus, if cubed financial leverage ratio increases or decreases by one standard deviation, (mean=0.6246, $1 \mathrm{SD}=0.2619)$ it would cause the stock market price to decline more or less than average by 22.3 percent per unit respectively. In financial leverage terms, it is equivalent to an increase of financial leverage ratio from 0.854 to 0.96 (increased by 12.38 percent) or a decrease from 0.854 to 0.71 (decreased by 16.57 percent) for that similar change of stock market price. In other words, an individual firm that raises debts relative to equity ratio more often than mean level (for example higher by 12.38 percent) would expect to experience a more decline than average in stock price by 6.8 percent should a crisis occurs. A firm would expect to see a lower than average drop in stock market price by the same amount (i.e., 6.8 percent) if that firm has leverage ratio lower than a mean level of 16.57 percent. This translates the inclusion of cubed function of financial leverage. A small increase in financial leverage causes a higher drop of stock market price whereas a larger decrease in leverage is required to have the same impact on stock price on the opposite direction. In Appendix D, Figure 4.7 shows the 
relationship between the average level of leverage ratio and predicted change of stock market price.

The second predictor variable is the accumulated rate of change of financial leverage ratio (rrL). It shows two significant relationships with two other mediating variables. The first relationship is a positive significant relationship between (rrLev) and (rrA2a) at $\alpha=0.001$ level of significance and the coefficient 0.61 shows the goodness of the fit for the best possible linear relationship between ( $r \mathrm{rL})$ and $(\mathrm{rrA} 2)$. If the accumulated rate of change of leverage increases by one standard deviation, the accumulated rate of change of this fraction of assets would increase by 0.61 per unit. The second relationship is between (rrLev) and ( $r \mathrm{rCR})$ which is a negative significant relationship at $\alpha=0.001$ level of significance. The coefficient -0.522 shows the goodness of the fit for the best possible linear relationship between (rrLev) and (rrCR). If the accumulated rate of change of leverage increases by one standard deviation, the accumulated rate of change of this current ratio would decline by -0.522 per unit. In order to calculate the total indirect effect of accumulated rate of change of leverage on the outcome $Y 1$, we need to add both multiplications of the two path coefficients $\left(0.61^{*}\right.$ $\left.0.19+-0.52^{*} 0.30\right)$ to get -0.27 . In short, an institution that experiences growth in leverage ratio over two years higher than mean level by one standard deviation would expect a more than average decline in stock market price by 8.26 percent. However, if it is lower than a mean level by one standard deviation, it would expect a less than average decline in stock market price by the same amount. In Appendix D, Figure 4.8 shows the relationship between the accumulative change of leverage ratio and predicted change in stock market price, and Table 4.10 shows mean values for each 
financial ratio and predicted change in stock market price from average according to an increase or a decrease by one standard deviation for each.

Finally, the Table 5.8 shows the correlation coefficient (standardized covariance) between both predictor variables; the average level of financial leverage and its accumulated rate of change to equal 0.33 which indicates the goodness of the fit for the best possible linear relationship between the two variables. An individual firm that accumulates debts at rate faster than raising equity tends to have higher average level of financial leverage 33 percent of the time. 


\section{EMPERICAL ANALYSIS BASED ON MULTIVARIABLE FRACTIONAL POLYNOMIALS}

\subsection{ANALYSIS AND PROCESSING}

A series of models are created by the use of Multivariable Fractional Polynomial methods (MFP) over varying lags to examine which best-fit model illustrates the data and tests the relationships between the outcome and continuous covariates as introduced by Royston and Altman (1994) and modified by Sauerbrei and Royston (1999). Typically, the multivariable fractional polynomial (MFP) starts with a full model that includes all predictor variables that of our interest to investigate. Consequently, MFP technique run backwards eliminates and systematically transforms continuous covariates throughout repeated cycle processes to test against other models.

Model 1 (MFP4QY1) is used to examine the relationships between financial ratios and the first outcome (Y1), while the same test is applied with the second outcome (Y2) in model 4 (MFP4QY2) over four quarters lag. Models 2 (MFP8QY1) and 5 (MFP8QY2) test the same relationships over eight quarters lag, and models 3 (MFP12QY1) and 6 (MFP12QY2) over twelve quarters lag.

Different criteria to test the goodness of fit for each subsequent model are carried out. The most importantly criterion is the coefficient of determination $\left(R^{2}\right)$ in conjunction with other criteria including Root MSE, the F statistic and associated p-values. Second, the normality test carries through the command "swilk" which performs the test of "Shapiro Wilk" and the associated p-value. This test is based upon the pre-assumption that the residual is normally distributed. If it becomes significant at a certain level (i.e. 
0.05), we can reject the null hypothesis that the residual is normally distributed. Third, the Breusch-Pagan and White's Test are used to test for heteroskedasicity which tests the null hypothesis that the variance of the residual is constant and identical. Therefore, if the associated p-values are insignificant at level 0.05 , then we accept the null hypothesis rather than rejecting that the variance is homogenous.

In addition, we use two different measures for the purpose of analyzing and testing the model specification errors, both which should indicate insignificant $p$-values in order to accept the model. Otherwise the model needs to be reconsidered. The first test is carried out by the command 'linktest' which refits the model using two new variables. The variable of prediction (_hat) and its associated $p$-value need to be significant and the variable of squared prediction (_hatsq) and its associated p-value should be insignificant if the model is specified correctly. The second test is carried out by the command "ovtest." It performs a regression specification error test (RESET) for omitted variables. It also refits the model using new variables. The associated $p$-value needs to be insignificant in order to have a correctly specified model (Ramsey, 1969). Finally, after performing the above fit indices, we need to test the plausibility of the estimates from a theoretical standpoint and for the consistency of the predicted relationships between variables.

\subsection{MODEL COMPARISONS}

In Appendix E, Table 5.1 presents fit indices results of all models implemented by the MFP technique. The table indicates that model 2 shows the best-fit model among the rest. First, it shows the highest percentage of the outcome variances that were explained by this model (i.e. $R^{2}=52 \%$ ). Model 6 shows the closest model in terms of the 
coefficient of determination (i.e. $R^{2}=28 \%$ ). Second, model 2 shows the most significant $F$ statistic associated p-value (i.e. 0.0000) and the least value of Root MSE (i.e. 0.20) which indicates that the overall model is significant to predict $\mathrm{Y} 1$, while the closest model was model 1 with p-value and Root MSE equal to 0.0006 and 0.26 respectively. Third, model 2 show that we cannot reject the null hypothesis that the residual was normally distributed at level of 0.05 (swilk test's $p$-value= 0.26 ). However, we can reject the null hypothesis for models 1 and 3 (i.e. p-value $=0.005$ and 0.009 ) respectively. Fourth, model 2 shows insignificant results associated with measures of heteroskedasticity at the level of 0.05 (i.e. imtest's $p$-value $=0.44$ and hettest's $p$-value $=0.93)$ and that indicates the model has constant and identical residual variances. Fifth, model 2 shows insignificant results associated with model specification error tests (linktest and ovtest) at level of 0.05 (i.e. 0.31 and 0.22 ) respectively. Accordingly, this model does not need to be reconsidered for omitted variable bias.

Model 1 examines the effect of four quarters lagged continuous covariates from financial statements on the first outcome " $\mathrm{Y}$ " (the percentage change in stock market price during crisis time). The model finds only one significant negative linear relationship at a level of $\alpha=0.05$ between the average level of financial leverage ratio and dependent variable (Y1) as shown in equation (1). The mean level of financial leverage ratio is equal to 0.81709 , which means approximately 82 percent of the total capital raised by debt or equivalently a debt multiplier equal to 1.20 . For a firm that has a leverage ratio of one standard deviation $(S D=0.19)$ higher than the mean level (i.e. 1.007), meaning that by itself the capital includes negative equity due to losses, the model finds a more than average decline in stock market price by 13.5 percent or a less 
than average decline by 13.9 percent if it is one standard lower than mean level (i.e. 0.62 ) which means only 62 percent of total capital raised by debt.

$(\%$ Y1 $)=-0.6368-0.7246 *\{$ Lev -0.8203$\}$

Model 2 examines the effect of eight quarters lagged continuous covariates from financial reports on the first outcome "Y1" (the percentage change in stock market price during crisis time). The model finds two significant nonlinear relationships at the level of $\alpha=0.05$ between two financial ratios and the dependent variable (Y1) as shown in equation (2). The first is a negative relationship between the average level of financial leverage ratio (Lev) and change of stock market price as shown in Figure 5.1 in Appendix E.

For a firm that has leverage ratio is one standard deviation higher than mean level when a crisis hit the economy (i.e. $S D=0.18$ and mean $=0.82$ ), the model finds a more than average decline in stock market price by 23.7 percent or a less than average decline by only 16.9 if the leverage ratio is one standard deviation lower than mean level. Equivalently, in debt multiplier terms, with a leverage ratio of one (total capital is equal to total debt), the model finds that stock market price will drop more than average by 23.7 percent, while at a ratio of 1.56 (total capital is higher than debt level by 56 percent), the stock market price will drop less than average by 16.9 percent. Thus, the model shows a larger negative effect on an individual institution stock market price change than positive effect for one standard deviation change in either direction. This reveals the economic explanation for having cubed leverage ratio in this model. 
Second, a positive relationship between the accumulated time-weighted rate of change of current ratio ( $\mathrm{rCR}$ ) and the change in stock market price is shown in Figure 5.2 in Appendix E. If a firm's current assets grow at rate faster than that of current liabilities, that leads into higher growth rate of current ratio and improves its ability to meet its current obligations. Therefore, a firm that maintains positive accumulated rate of change of current ratio by one standard deviation (i.e. $S D=0.22$ ) higher than mean level (i.e. -0.0374 ), the model finds a less than average decline in stock price by 13.73 percent or a more than average decline by 13.55 percent if it is one standard deviation below the mean. However, an observed outlier firm (HCBK) shows a negative relationship between this ratio and stock market change. Excluding this firm would result in having the same positive linear relationship between $\operatorname{rrCR}$ and $\mathrm{Y} 1$ and a very minimal effect on the first part (Lev) of the equation. Ultimately, Figures 5.3 and 5.4 in Appendix E show the predicted drops in stock market prices for financial firms covered in this study starting from the highest drop to the least according to their average levels of leverage ratios and the accumulated rate of change of current ratios over two years lag as predicted by model 2 in $2007 q 2$ and $2007 q 3$, respectively.

$(\% \mathrm{Y} 1)=-0.6111-0.5514^{*}\left\{(\mathrm{Lev})^{3}-0.5690\right\}+0.0138^{*}\left\{[\mathrm{rrCR}+0.648]^{-0.5}-1.2812\right\}+$ $0.6416^{*}\{[\mathrm{rrCR}+0.648]-0.6092\}$

Model 3 examines the effect of twelve quarters lagged continuous covariates from financial reports on the first outcome "Y1" (the percentage change in stock market price during crisis time). The model finds only one significant negative linear relationship at level of $\alpha=0.05$ between the accumulated growth rate of the ratio of financial leverage and first outcome $\mathrm{Y} 1$ as shown in equation (3). The interesting point about this 
model is the inclusion of accumulated rate of change of leverage ratio instead of average level to predict the outcome by using longer lag (i.e. 12 quarters lag). The model finds a more than average decline in stock market price by 12.8 percent if accumulated growth rate of leverage ratio is higher than mean level by one standard deviation and a less than average decline by 11.15 percent if it is one standard deviation lower than mean level (i.e. $\mathrm{SD}=0.07$ and mean level $=-0.023$ ).

$(\%$ Y 1$)=-0.6347-1.7112^{*}\{\mathrm{rLev}+0.02781\}$

Model 4 examines the effect of four quarters lagged continuous covariates from financial reports on the second outcome "Y2" (the percentage change in average stock market price during crisis time). The model finds only one significant negative linear relationship at level of 0.05 between the average level of financial leverage ratio and dependent variable (Y2) as shown in equation (4). For a firm that has leverage ratio of one standard deviation higher than mean level (i.e. $\mathrm{SD}=0.19$ and mean level $=$ 0.81709), the model finds a more than average decline in stock market price by 10.3 percent or a less than average decline by 10.68 percent if it is one standard deviation lower than mean level. This means if the total debt represents only 62 percent of total capital, the stock market price tends to decline less than average by 11 percent.

$(\%$ Y $)=-0.4501-0.5527\{$ Lev -0.8203$\}$

Model 5 examines the effect of eight quarters lagged continuous covariates from financial reports on the second outcome "Y2" (the percentage change in average stock market price during crisis time). For a firm that is one standard deviation higher than mean level (i.e. $\mathrm{SD}=0.19$ and mean level $=0.81709$ ), the model finds a more than 
average decline in stock market price by 10.14 percent or a less than average decline by 11.09 percent when leverage ratio is about one standard deviation (i.e. $S D=0.18$ ) above or lower mean level (i.e. 0.8285), respectively. This reveals the crucial role of capital structure in predicting the change of stock market price. If the total debt represents only 64 percent of total capital, the stock market price tends to decline less than average by 11 percent, but if debt represents 100 percent of total capital, a decline of stock market price more than average by 10 percent is the most likely.

$(\%$ Y $)=-0.4377-0.59\{$ Lev -0.828$\}$

Model 6 examines the effect of twelve quarters lagged continuous covariates from financial reports on the second outcome "Y2" (the percentage change in average stock market price during crisis time). The model finds only one significant nonlinear relationship at level of 0.05 between the average level of investing cash flow per asset ratio and dependent variable (Y2) as shown in equation (6). The model finds a more than average decline in stock market price by 40.44 percent for a firm that has a ratio above mean level by one standard deviation (i.e. $\mathrm{SD}=0.01408$ and mean level= 0.014466). On the other hand, if a firm is at one standard deviation lower than the mean, the model finds a more than average decline in stock market price by only 8.2 percent. The only range that shows a less than average decline in stock market price when this ratio is lower than mean level by just one quarter of a standard deviation to 0.01799 , which causes a less than average decline in stock price only by 3.2 percent. Thus, a very short range of this ratio can have a positive impact on stock price and the economic analysis of having a sharp decline in stock prices when such ratio increases 
is that an institution facing liquidity problems and selling assets would generate cash. ${ }^{1}$ In addition, this model shows a better fit relative to models 4 and 5 which had the same outcome (Y2), and model 3 in which both share the same lag.

$$
\begin{aligned}
& (\% Y 2)=-0.2967-8.0829^{*}\left\{\left[(I C F+0.05969)^{*} 10\right]^{3}-0.08467\right\}-15.1864^{*}\{[(I C F+ \\
& \left.\left.0.05969)^{*} 10\right]^{3 *} \log \left(\left[(I C F+0.05969)^{*} 10\right]\right)+0.06968\right\}
\end{aligned}
$$

From the previous discussion and model comparisons shown in Table 5.1, we found that model 2 is a good fit-model among the six models as it meets all criteria presented in this study. In most of the literature covered in this dissertation, capital structure as presented by leverage ratio was the major predictor of the financial crisis. Thus, model 2 offers the same results as much of the relevant literature, but with another dimension to measure a firm's liquidity. The inclusion of the cubed financial leverage ratio gives this model additional explanatory power to predict the outcome (i.e. $\left.R^{2}=52 \%\right)$. This nonlinear relationship between financial leverage ratio and the change in stock market price indicates a major impact on stock price if the ratio exceeds certain level above the mean, whereas the impact on stock price would be moderate if the ratio was below the mean by the same amount. Finally, the most important feature of model 2 is that it is the only model to include two independent variables; the ratio of financial leverage as a measure of capital structure and current ratio as a measure of liquidity. The specific comparisons regarding the output of coefficients of these regressions are highlighted in Table 5.2 in Appendix E.

\footnotetext{
${ }^{1}$ An increase in the ratio of investing cash flow per asset indicates positive inflow of cash to the firm through the sale of investment assets which would be a sign of liquidity problems and buy new assets would show negative or outflow of cash.
} 


\section{OUT-OF-SAMPLE TESTS AND RESULTS}

The purpose of this dissertation is to introduce measures that provide regulators and a variety of financial reports' users with early warning indicators associated with financial institution's performance, profitability, and liquidity which will allow such firm to absorb unexpected economic downturns. For this goal, we conduct the out-of-sample test to test the best-fit model in this study (Model 2) as mentioned previously in chapter 5. Model 2 provides two useful early warning indicators including financial leverage and a balance between current assets and current liabilities. These two balance sheet items can be used to predict to what extent a firm is impacted according to its fundamental characteristics relative to the industry levels given that a systemic event occurred.

The period of the out-of-sample test was a period of recovery. Three subsamples generated from financial statements, each lagged on different periods $(4,8$ and 12 quarters) predict the expected change in stock market price between 2010q2 to 2011q1, proven to be a major rise as marked by benchmark. It is important to note that there is only one systemic event in the data. Therefore, the out-of-sample test examines the relationships between the same variables and change of stock market price. The output coefficients and the comparisons between models are shown in Tables 6.1 in Appendix $\mathrm{F}$.

We find only one positive significant relationship between current ratio "the balance between current asset and current liabilities" and the change of stock market price at level of 0.05 . However, the ratio of leverage is not included. Model 2 in chapter 5 is the only model to include current ratio in addition to financial leverage ratio as a set to predict the outcome. 
The out-of-sample model finds that a firm that has higher current ratio than mean level by one standard deviation will expect a more than average rise in stock market price by 10 percent, or less than average rise by 10 percent if it is one standard deviation lower than mean level. In other words, if the average current asset is higher than average current liability by 79 percent, the model finds a more than average increase in stock market price by 10 percent, or less than average increase by the same percentage if the average current asset is almost equal to average current liability as shown in equation (7) and Figure 6.1 in Appendix F.

$$
(\% \mathrm{Y} 1)=0.18+0.118\{\mathrm{CR}-0.952\}
$$




\section{CONCLUSIONS}

In this dissertation, we attempted to locate and analyze key economic factors that existed during the pre-crisis phase and the overall performance of individual firms in order to predict what firms will suffer the most based upon their pre-crisis performance. By examining each firm's financial records by themselves, we analyzed indicators deviating from the norm from those financial reports as potential key warning signs. We also tested the outcomes against leading variables in order to understand how multinational firms identified in this study were affected.

We used two estimation techniques to conduct the analysis, Structural Equation Modeling (SEM) and Multivariable Fractional Polynomials (MFP), to examine which financial ratios could be used as early warning signals to a systemic crisis. The two models used in this dissertation attempted to predict the expected change in stock market price based upon an individual institution's current characteristics had a systemic crisis occurred. We implemented the two approaches to compute each financial ratio over three different lags. In the first approach, we calculated average levels of each ratio over each lag in order to eliminate outliers' effects. In the second approach, we computed the accumulated time-weighted rate of change of each ratio over each lag in an attempt to address the pro-cyclicality issues where risk factors accumulated over periods of growing times.

Both techniques found the two years lag to be the most significant period to predict the stock market effects of systemic crisis. The first technique (SEM) indicated that both approaches of computing the ratio of financial leverage were significant in terms of predicting the outcome after controlling for asset turnover, short- and long-term 
investment assets, and current ratios as intervening variables. The second technique (MFP) found that the average level approach to calculate financial leverage and accumulated rate of change approach to calculate current ratio were both significant to predict stock market effects in such a crisis.

SEM3-8Q Model was tested using the structural equation modeling technique which predicted stock market effects of systemic crisis as the best-fit model. A small change of financial leverage ratio would be amplified by the cubed function which reveals the economic explanation for having cubed leverage ratio to reflect its positive significant effect on assets turnover ratio $\left(\mathrm{ATR}^{-0.5}\right)$ and its indirect negative effect on change of stock market price (Y1). For example, if the two years lagged cubed average level of leverage ratio increases by one standard deviation, it caused $\left(\operatorname{ATR}^{-0.5}\right)$ to increase by 0.62 of its standard deviation. Thus, there was an indirect negative effect of the predictor variable $\left(\mathrm{L}^{3}\right)$ on the outcome $(\mathrm{Y} 1)$. If cubed financial leverage ratio increased or decreased by one standard deviation, (mean $=0.6246,1 S D=0.2619)$ it caused a more or less than average decline in stock market price by 22.3 percent per unit respectively. In financial leverage terms, it is equivalent to an increase of financial leverage ratio from 0.854 to 0.96 (increased by 12.38 percent) or a decrease from 0.854 to 0.71 (decreased by 16.57 percent) for that same more or less than average change in stock market price respectively. In other words, an individual firm that raises debts relative to equity to higher than the mean level (for example higher by 12.38 percent) would expect to experience a more than average drop in stock price by 6.8 percent had a crisis occurred. A firm would expect to see a less than average drop in stock market price by the same amount 6.8 percent if that firm had a leverage ratio lower than mean 
level by 16.57 percent. A small increase of financial leverage caused a high drop of stock market price whereas a larger decrease of leverage is required to have the same impact on stock price in the opposite direction.

The accumulated rate of change of the financial leverage ratio (rrL) showed two significant relationships with two other mediating variables. The first relationship was positive and significant with accumulated rate of change of short- and long-term investment asset ratio. The second relationship was negative and significant with accumulated rate of change of current ratio. Therefore, there was a negative indirect effect of the accumulated rate of change of leverage on the outcome Y1. In short, an institution that experienced growth in its leverage ratio over two years greater than mean level by one standard deviation should have expected a more than average decline in stock market price by 8.26 percent. However, if it was lower than the mean level by one standard deviation it should have expected a lower than average decline in stock market price by the same amount. In addition, the model indicated that the correlation between the accumulated rate of change and the average level of financial leverage was 0.33 .

The multivariable fractional polynomials technique introduced in model 2 predicted stock market effects of systemic crisis as the best-fit model as shown in equation (2). The model found one negative significant nonlinear relationships at the level of $\alpha=0.05$ between the average level of leverage ratio and stock market effects of systemic crisis. For a firm that had a leverage ratio at one standard deviation higher than the mean level when a crisis hit (i.e. $S D=0.18$ and mean $=0.82$ ), the model found a greater than average decline in stock market price by 23.7 percent or a lower than 
average decline in stock market price by only 16.9 percent if it was one standard deviation lower than the mean level. Equivalently in a debt multiplier terms, the leverage ratio of 1 (total capital was equal to total debt), the model found a more than average drop in stock market price by 23.7 percent, and at a ratio of 1.56 (total capital was higher than debt level by 56 percent), there was a less than average drop in stock market price by 16.9 percent. Thus, the model showed a larger negative effect on an individual institution stock market price change than positive effect for one standard deviation in either direction. This reveals the economic explanation for having cubed leverage ratio in this model.

Another positive linear significant relationship was found between the accumulated rate of change of current ratio and change in stock market price. If a firm's current assets grew at rate faster than that of current liabilities, that leads to a higher growth rate of the current ratio and improves the institution's ability to meet its current obligations. Therefore, for a firm that maintained a positive accumulated current ratio higher than the mean level (i.e. -0.0374 ) by one standard deviation (i.e. $S D=0.22$ ), the model found that a less than average drop in stock price by 13.73 percent or a more than average drop by 13.55 percent if it was one standard deviation below the mean. In short, we found the multivariable fractional polynomials technique and model 2 to be more reliable and plausible relative to the structural equation modeling technique and model SEM3-8Q due to higher $R^{2}$ (i.e. 52 percent versus 34 percent respectively) and because of its simplicity.

To some extent the out-of-sample tests supported our conclusion. First, the eight quarters lagged model showed the highest explanatory power (i.e. $R^{2}=43.6$ percent). 
Second, the only significant predictor in the out-of-sample tests was the current ratio which was shown only in model 2 of the second approach (MFP) as another predictor alongside leverage ratio. The out-of-sample model found a positive significant linear relationship between the accumulated rate of change of current ratio and the change in stock market price, while in model 2 the relationship was between the average level of current ratio and the outcome. Yet, that still entailed a similar impact in terms of expected sign. For example, if the average current asset was higher than the average current liability by 79 percent, a higher than average rise in stock market price by 10 percent would occur. However, if the current asset was almost equal to the current liability, the possible effect on stock market price would be a lower than average rise by 11 percent which indicates that a firm will not be able to liquidate all current asset when required to meet its obligations as shown in Figure 6.1 and in equation (7). In addition, the out-of-sample results confirmed that the changes in pre-crisis stock prices are less sensitive to the leverage ratio but more sensitive during crisis as argued by many scholars.

\subsection{POLICY IMPLICATIONS}

Off-balance sheet items would play a crucial role in measuring and managing risk if they were pointed out and disclosed due to their expected large effects on various financial ratios. Thus, off-balance sheet items certainly increase financial risks and uncertainty. Consequently, more information about a financial institution's position and performance would improve our prediction of quantifying the damage to a firm had a systemic crisis occurred. Studying off-balance sheet and cash flow items where positive cash flow (or liquidity) is the key to survival as creditors can be paid provides a good 
opportunity to take preventive measures to keep an entity from heading into bankruptcy. Thus, they are potentially promising aspects for future research that would help minimize the effects of externality problems.

Finally, financial regulators such as the Securities and Exchange Commission need to impose policies to ensure the reliability and accuracy of the information in financial statements. For example, hidden risks associate with off-balance sheet items, risks associated with counterparties, and the effectiveness of risk management in each firm should be disclosed in these reports. On the other side, regulating committees such as the Basel Committee need to impose rules to ensure firms' ability to meet the need of capital during crises. However, many of the financial firms during the systemic crisis in 2008 were in compliance with the minimum capital requirements imposed by the Basel Committee, which indicated the importance of role of capital ratio and leverage requirements in an attempt to keep the banks from making too many risky investments. In fact, the massive rescues of these firms led to modify such capital requirements through introducing Basel III by implementing a 1/N rule for leverage ratio. In 2010, Basel Committee introduced a Tier I leverage ratio at three percent, which meant that an individual firm can leverage its equity up to 33 times. However, the total risk-adjusted capital requirement stays the same as before at 8 percent. The Tier I capital requirement will increase to 6 percent by 2019, and banks can use capital from Tier II to fill the gap between Tier I and total capital requirements. Andrew Haldane (2012) argued that a 7 percent leverage ratio instead of 3 percent was needed in order for large banks to survive the financial crisis in 2008 , and a 4 percent leverage ratio is required to minimized Type I and II crisis errors. Therefore, more analysis and 
investigation on capital structure ratio, which defined the relationship between equity and total capital, and the liquidity ratio, which proved to be an important predictor of firms' performance during the crisis and post-crisis periods, are two potential promising fields for future research that would help minimize the effects of unexpected financial risks. 


\section{APPENDIX A}

This table contains the names and codes of the U.S. financial firms covered in this dissertation.

\begin{tabular}{|c|c|c|c|}
\hline Number & Code & Name & Category \\
\hline 1 & AIG & American International Group Inc & Insurance \\
\hline 2 & ALL & The Allstate Corporation & Insurance \\
\hline 3 & AMP & Ameriprise Financial, Inc. & Others \\
\hline 4 & AXP & American Express Company & Others \\
\hline 5 & BAC & Bank of America Corp & Banks \\
\hline 6 & BBT & BB\&T Corporation & Banks \\
\hline 7 & $\mathrm{BK}$ & $\begin{array}{l}\text { The Bank of New York Mellon } \\
\text { Corporation }\end{array}$ & Banks \\
\hline 8 & BLK & BlackRock, Inc. & Others \\
\hline 9 & BRK & Berkshire Hathaway Inc. & Insurance \\
\hline 10 & C & Citigroup Inc & Banks \\
\hline 11 & CB & The Chubb Corporation & Insurance \\
\hline 12 & $\mathrm{CBH}$ & Commerce Bancorp Inc. & Banks \\
\hline 13 & CMA & Comerica Incorporated & Banks \\
\hline 14 & CME & $\begin{array}{l}\text { Chicago Mercantile Exchange } \\
\text { Holdings Inc. }\end{array}$ & Others \\
\hline 15 & ETFC & E TRADE Financial Corporation & Brokers \\
\hline 16 & FIS & Fidelity National Information Services & Others \\
\hline 17 & FITB & Fifth Third Bancorp & Others \\
\hline 18 & FNMA & $\begin{array}{l}\text { Federal National Mortgage } \\
\text { Association }\end{array}$ & Others \\
\hline 19 & GS & Goldman Sachs Group Inc & Brokers \\
\hline 20 & HBAN & Huntington Bancshares Incorporated & Banks \\
\hline 21 & HCBK & Hudson City Bancorp, Inc. & Banks \\
\hline 22 & HIG & Hartford Financial Services Group & Insurance \\
\hline
\end{tabular}




\begin{tabular}{|c|c|c|c|}
\hline & & Inc. & \\
\hline 23 & HUM & Humana Inc. & Insurance \\
\hline 24 & JPM & JPMorgan Chase \& Co. & Banks \\
\hline 25 & KEY & KeyCorp & Banks \\
\hline 26 & $\mathrm{~L}$ & Loews Corp. & Insurance \\
\hline 27 & LEHMQ & Lehman Brothers Holdings Inc & Brokers \\
\hline 28 & MA & MasterCard Inc. & Others \\
\hline 29 & MER & Merrill Lynch and Co. Inc. & Brokers \\
\hline 30 & MI & Marshall \& Ilsley Corp. & Others \\
\hline 31 & MS & Morgan Stanley & Brokers \\
\hline 32 & MTB & M\&T Bank Corporation & Banks \\
\hline 33 & $\mathrm{NCC}$ & National City Corporation & Banks \\
\hline 34 & NTRS & Northern Trust Corporation & Banks \\
\hline 35 & NYB & New York Community Bancorp Inc. & Banks \\
\hline 36 & PBCT & People's United Financial, Inc. & Banks \\
\hline 37 & PGR & The Progressive Corporation & Insurance \\
\hline 38 & PNC & Financial Services Inc. & Banks \\
\hline 39 & RF & Regions Financial Corporation & Banks \\
\hline 40 & SCHW & Charles Schwab Corp & Brokers \\
\hline 41 & SNV & Synovus Financial Corp. & Banks \\
\hline 42 & STI & SunTrust Banks, Inc. & Banks \\
\hline 43 & STT & State Street Corporation & Banks \\
\hline 44 & TROW & T. Rowe Price Group, Inc. & Brokers \\
\hline 45 & TRV & Travelers Companies Inc & Insurance \\
\hline 46 & UB & Unionbancal Corp. & Banks \\
\hline 47 & UNP & Union Pacific Corporation & Others \\
\hline 48 & WAMUQ & Washington Mutual Inc. & Banks \\
\hline
\end{tabular}




\begin{tabular}{llll}
\hline 49 & WB & Wachovia Corp. & Banks \\
50 & WFC & Wells Fargo \& Co & Banks \\
51 & WU & The Western Union Company & Banks \\
52 & ZION & Zions Bancorporation & Banks \\
\hline
\end{tabular}




\section{APPENDIX B}

This table shows the descriptions of all dependent and independent variables included in models implemented by both techniques covered in this study over two years lag.

\begin{tabular}{|c|c|}
\hline Variables & Description \\
\hline Y1 & $\begin{array}{l}\text { Percent change in stock market price between max-point and min-point } \\
\text { during the financial crisis from } 2007 q 3 \text { to } 2009 q 1 \text {. }\end{array}$ \\
\hline Y2 & $\begin{array}{l}\text { Percent change in stock market price between average max-point and } \\
\text { average min-point during the financial crisis from } 2007 q 3 \text { to } 2009 q 1 \text {. }\end{array}$ \\
\hline $\mathrm{m} 2 \mathrm{~L}$ & Average level of financial leverage ratio. \\
\hline $\mathrm{m} 20$ & Average level of operating cash flow ratio. \\
\hline $\mathrm{m} 2 \mathrm{~F}$ & Average level of financing cash flow ratio. \\
\hline m2IF & Average level of investing cash flow ratio. \\
\hline $\mathrm{m} 2 \mathrm{R}$ & Average level of asset turnover ratio. \\
\hline $\mathrm{m} 2 \mathrm{Cr}$ & Average level of current ratio. \\
\hline $\mathrm{m} 2 \mathrm{l}$ & Average level of return on asset ratio. \\
\hline$m 2 \log A$ & Natural logarithm of book-valued assets. \\
\hline $\mathrm{m} 2 \mathrm{~A} 2 \mathrm{a}$ & Average level of short- and long-term investment assets ratio. \\
\hline rr8qL & Accumulated time-weighted rate of change of financial leverage ratio. \\
\hline $\mathrm{rr8qO}$ & Accumulated time-weighted rate of change of operating cash flow ratio. \\
\hline rr8qF & Accumulated time-weighted rate of change of financing cash flow ratio. \\
\hline rr8qlF & Accumulated time-weighted rate of change of investing cash flow ratio. \\
\hline $\operatorname{rr} 8 \mathrm{qR}$ & Accumulated time-weighted rate of change of asset turnover ratio. \\
\hline $\mathrm{rr} 8 \mathrm{qCr}$ & Accumulated time-weighted rate of change of current ratio. \\
\hline rr8ql & Accumulated time-weighted rate of change of return on asset ratio. \\
\hline $\operatorname{rr} 8 q A 2 a$ & $\begin{array}{l}\text { Accumulated time-weighted rate of change of short- and long-term } \\
\text { investment assets ratio. }\end{array}$ \\
\hline
\end{tabular}




\section{APPENDIX C}

Table 3.4: This table shows the correlation coefficients between variables included in both techniques SEM and MFP over two years lag.

\begin{tabular}{|c|c|c|c|c|c|c|c|c|c|c|c|c|}
\hline & Y1 & Y2 & $\mathrm{m} 2 \mathrm{~L}$ & $\mathrm{~m} 20$ & $\mathrm{~m} 2 \mathrm{~F}$ & $\mathrm{~m} 2 \mathrm{IF}$ & $\mathrm{m} 2 \mathrm{R}$ & $\mathrm{m} 2 \mathrm{Cr}$ & $\mathrm{m} 2 \mathrm{I}$ & $\mathrm{m} 2 \log A$ & $\mathrm{~m} 2 \mathrm{~A} 2 \mathrm{a}$ & $r r 8 q L$ \\
\hline Y1 & 1.0000 & & & & & & & & & & & \\
\hline Y2 & 0.7431 & 1.0000 & & & & & & & & & & \\
\hline $\mathrm{m} 2 \mathrm{~L}$ & -0.4639 & -0.3345 & 1.0000 & & & & & & & & & \\
\hline $\mathrm{m} 20$ & 0.3189 & 0.2556 & -0.7693 & 1.0000 & & & & & & & & \\
\hline $\mathrm{m} 2 \mathrm{~F}$ & -0.0451 & -0.0580 & 0.4352 & -0.3438 & 1.0000 & & & & & & & \\
\hline $\mathrm{m} 2 \mathrm{IF}$ & -0.1522 & -0.1338 & 0.1414 & -0.3430 & -0.6702 & 1.0000 & & & & & & \\
\hline $\mathrm{m} 2 \mathrm{Cr}$ & 0.2888 & 0.1317 & -0.7806 & 0.6355 & -0.3126 & -0.1392 & 0.4851 & 1.0000 & & & & \\
\hline $\mathrm{m} 2 \mathrm{I}$ & 0.3321 & 0.2396 & -0.8791 & 0.8056 & -0.4224 & -0.1595 & 0.5105 & 0.8879 & 1.0000 & & & \\
\hline$m 2 \log A$ & -0.4395 & -0.4015 & 0.6051 & -0.7149 & 0.2072 & 0.2641 & -0.4692 & -0.3318 & -0.6051 & 1.0000 & & \\
\hline $\mathrm{m} 2 \mathrm{~A} 2 \mathrm{a}$ & -0.3670 & -0.2322 & 0.7411 & -0.5988 & 0.3506 & 0.1362 & -0.4827 & -0.4836 & -0.5524 & 0.3769 & 1.0000 & \\
\hline rr8qL & -0.2746 & -0.1555 & 0.3189 & 0.0856 & 0.1903 & -0.2230 & 0.1694 & -0.0651 & -0.1264 & 0.2284 & 0.3040 & 1.0000 \\
\hline rr8q0 & -0.1247 & -0.1622 & 0.0390 & -0.0958 & -0.1852 & 0.2909 & -0.0222 & -0.0318 & -0.0352 & 0.0098 & 0.0815 & 0.0145 \\
\hline $\mathrm{rr} 8 \mathrm{qF}$ & 0.0013 & 0.1305 & 0.1100 & -0.0950 & 0.0935 & -0.0440 & -0.0624 & -0.1359 & -0.0959 & 0.1881 & 0.0705 & 0.0204 \\
\hline rr8qR & -0.0591 & -0.1231 & 0.2952 & -0.2547 & 0.1844 & 0.0742 & -0.2450 & -0.0275 & -0.2001 & 0.4276 & 0.2350 & 0.3479 \\
\hline $\mathrm{rr} 8 \mathrm{qCr}$ & 0.4240 & 0.2469 & -0.2006 & 0.0312 & 0.0054 & 0.1573 & 0.0096 & 0.1629 & 0.1622 & -0.1607 & -0.2015 & -0.5141 \\
\hline rr8qI & 0.1433 & 0.0653 & -0.0319 & -0.0524 & 0.0901 & -0.0400 & 0.0111 & 0.1047 & 0.0278 & 0.1681 & -0.0637 & 0.0782 \\
\hline \multirow[t]{2}{*}{ rr8qA2a } & -0.3306 & -0.1474 & 0.0724 & 0.0212 & 0.0277 & -0.0505 & -0.1183 & 0.2415 & 0.1284 & 0.2315 & 0.2512 & 0.5970 \\
\hline & rr8q0 & rr8qF & rr8qIF & rr8qR & $\mathrm{rr} 8 \mathrm{qCr}$ & rr8qI & rr8qA2a & & & & & \\
\hline rr8q0 & 1.0000 & & & & & & & & & & & \\
\hline$r r 8 q F$ & -0.0013 & 1.0000 & & & & & & & & & & \\
\hline rr8qIF & -0.0080 & -0.0248 & 1.0000 & & & & & & & & & \\
\hline rr8qR & -0.0723 & 0.0490 & -0.0276 & 1.0000 & & & & & & & & \\
\hline $\mathrm{rr} 8 \mathrm{qCr}$ & -0.0038 & 0.1122 & 0.0676 & -0.0544 & 1.0000 & & & & & & & \\
\hline rr8qI & -0.0224 & 0.0065 & 0.0112 & 0.3018 & 0.0082 & 1.0000 & & & & & & \\
\hline rr8qA2a & 0.0293 & -0.0295 & -0.0869 & 0.5052 & -0.3403 & 0.1467 & 1.0000 & & & & & \\
\hline
\end{tabular}

Table 3.5: This table reports the summary statistics of the two measures of systemic crisis effects as presented by percent change in stock market price between max- and min-point $(\mathrm{Y} 1)$ and percent change in stock market price between average-max- and average-min-point (Y2).

\begin{tabular}{|c|c|c|c|c|c|c|c|c|c|c|}
\hline variable & mean & sd & skewness & kurtosis & $\min$ & $\max$ & p5 & $\mathrm{p} 50$ & p75 & p95 \\
\hline Y1 & -.6175488 & .3063824 & .4385721 & 2.256917 & -1 & .131851 & -1 & $-.9036094-.6326801$ & -.3802816 & -.0973291 \\
\hline Y2 & -.4404002 & .3097637 & -.0265341 & 2.783467 & -1 & .4076407 & -1 & $-.6505669-.4468667$ & -.2057838 & -.0411814 \\
\hline
\end{tabular}


Table 3.6: This table reports the summary statistics of quarterly average levels of financial ratios over eight quarters lag.

\begin{tabular}{|c|c|c|c|c|c|c|c|c|c|c|c|}
\hline variable & mean & sd & skewness & kurtosis & $\min$ & $\max$ & p5 & $\mathrm{p} 25$ & p50 & p75 & p95 \\
\hline $\mathrm{m} 2 \mathrm{R}$ & .0534731 & .0927994 & 3.59769 & 18.46179 & .0028784 & .5595704 & .0060968 & .0124471 & .0141236 & .0558978 & .2185627 \\
\hline $\mathrm{m} 2 \mathrm{I}$ & .0077326 & .0101048 & 2.681981 & 10.2471 & .0014979 & .052131 & .0017857 & .002796 & .0034481 & .0076071 & .0343078 \\
\hline$m 2 \log A$ & 11.351 & 1.645882 & -.1027042 & 2.462259 & 7.867062 & 14.36913 & 8.531396 & 10.48935 & 11.47463 & 12.49797 & 14.091 \\
\hline $\mathrm{m} 2 \mathrm{~A} 2 \mathrm{a}$ & .7475525 & .2277978 & -1.486322 & 4.222622 & .051604 & .9817715 & .2335908 & .6908845 & .8503312 & .8759125 & .9650185 \\
\hline $\mathrm{m} 2 \mathrm{~L}$ & .8209321 & .1860514 & -1.947439 & 6.244827 & .1356153 & 1.039279 & .4038329 & .8106228 & .8964493 & .9160139 & .9612442 \\
\hline $\mathrm{m} 2 \mathrm{Cr}$ & .9798077 & 1.332739 & 4.13471 & 22.95396 & .147479 & 8.636918 & .1811194 & .2830393 & .6050249 & 1.215891 & 2.522109 \\
\hline m20 & .0083867 & .0161757 & 1.508364 & 5.429089 & -.0179863 & .0617878 & -.0130767 & .0017081 & .0040334 & .009848 & .0456184 \\
\hline $\mathrm{m} 2 \mathrm{~F}$ & .0075889 & .0173835 & .506368 & 3.979907 & -.0334844 & .0614396 & -.0184197 & -.0043603 & .004762 & .0177593 & .0424687 \\
\hline $\mathrm{m} 2 \mathrm{IF}$ & -.0138349 & .0151521 & -.9621272 & 4.358696 & -.0640147 & .0148109 & -.0467937 & -.0202635 & -.010928 & -.0036618 & .0076367 \\
\hline
\end{tabular}

Table 3.7: This table reports the summary statistics of quarterly accumulated timeweighted rate of change of financial ratios over eight quarters lag.

\begin{tabular}{|c|c|c|c|c|c|c|c|c|c|c|c|}
\hline variable & mean & sd & skewness & kurtosis & $\min$ & $\max$ & p5 & p25 & p50 & p75 & p95 \\
\hline rr8qR & -.087408 & .4948336 & -4.409453 & 27.14594 & -3.03447 & .7714185 & -.6566904 & -.0986376 & -.0199621 & .0682176 & .2976477 \\
\hline rr8qI & -.2048734 & 1.421793 & -2.739468 & 11.72925 & -5.959261 & 2.490877 & -3.996121 & -.2237224 & .0038831 & .1747086 & .8932959 \\
\hline rr8qA2a & -.0168037 & .1451427 & -.3845392 & 7.625019 & -.474646 & .4781195 & -.2755856 & -.0325033 & -.0103976 & .0180983 & .2169541 \\
\hline rr8qL & -.014796 & .1135865 & -3.77755 & 23.62547 & -.6635126 & .2423602 & -.1015183 & -.0196134 & -.0013072 & .008327 & .1027454 \\
\hline $\mathrm{rr} 8 \mathrm{qCr}$ & -.0374583 & .2275125 & 1.402547 & 10.76119 & -.6480256 & .994159 & -.3429099 & -.1539696 & -.0266435 & .0630403 & .1934873 \\
\hline rr8q0 & 12.63988 & 227.1277 & 5.034445 & 32.3063 & -330.3799 & 1426.156 & -173.8326 & -2.619771 & -.3354729 & 1.709112 & 15.90511 \\
\hline $\mathrm{rr} 8 \mathrm{qF}$ & 910.378 & 7141.731 & 6.643512 & 45.46565 & -3505.449 & 49211.14 & -835.7147 & -6.404725 & -.5600202 & 11.74677 & 92.4893 \\
\hline rr8qIF & 7722.719 & 55994.19 & 6.692399 & 45.87327 & -15565.92 & 387272.8 & -521.4584 & -16.60224 & -.9684458 & 3.742968 & 255.7206 \\
\hline
\end{tabular}




\section{APPENDIX D}

Figure 4.1: This figure shows the concepts behind a set of models discussed in SEM1. This set of models examines the effect of both assets turnover ratio and time-weighted rate of change of current ratio upon both average level and accumulated rate of change of financial leverage ratios in order to predict the changes in stock market prices (\%Y1 and \%Y2) over three different lags. Also, it shows the standardized outputs for model SEM1-Y1 over two years lag.

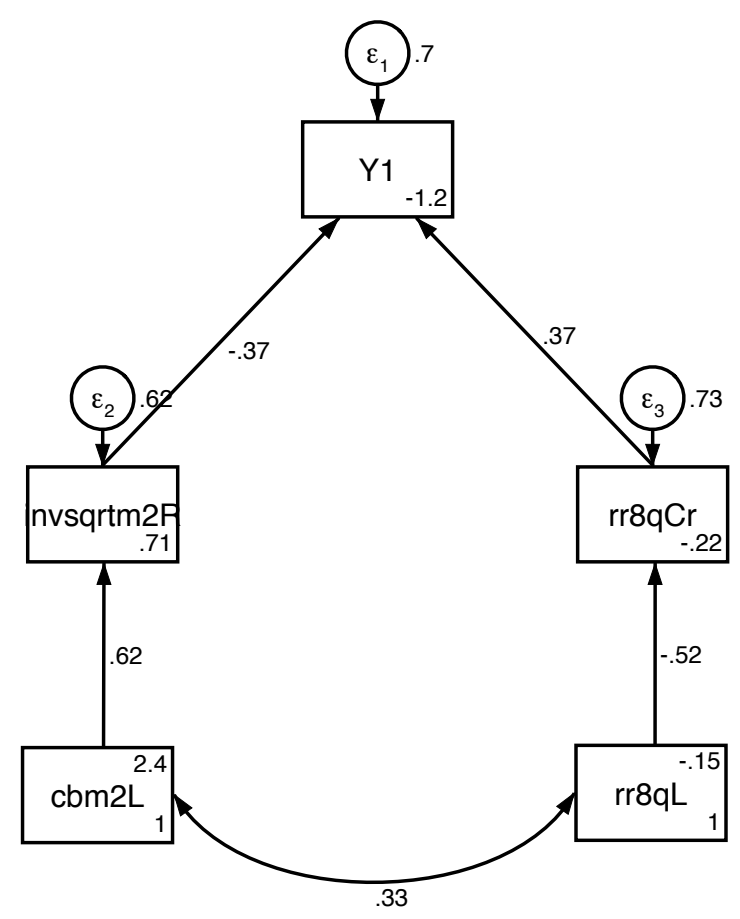


Figure 4.2: This figure shows the concepts behind a set of models discussed in SEM2. This set of models examines the effect of both assets turnover ratio and time-weighted rate of change of current ratio upon both average level and accumulated rate of change of financial leverage ratios, and adding another predictor variable, the natural log of firm's asset $(\log \mathrm{A})$ in order to predict the changes in stock market prices $(\% \mathrm{Y} 1$ and $\%$ Y) over three different lags. Also, it shows the standardized outputs for model SEM2$\mathrm{Y} 1$ over two years lag.

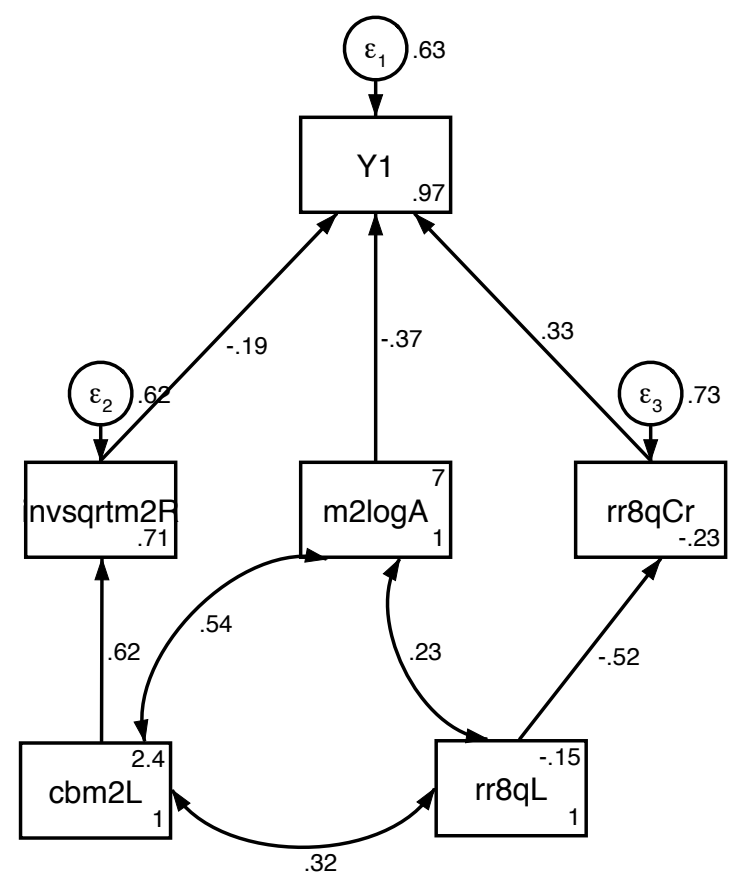


Figure 4.3: This figure shows the concepts behind a set of models discussed in SEM3. This set of models examines the effect of assets turnover ratio and time-weighted rate of change of current ratio and rate of change of short- and long-term investment assets ratio upon both average level and accumulated rate of change of financial leverage ratios in order to predict the changes in stock market prices (\%Y1 and \%Y2) over three different lags. Also, it shows the standardized outputs for model SEM3-Y1 over two years lag.

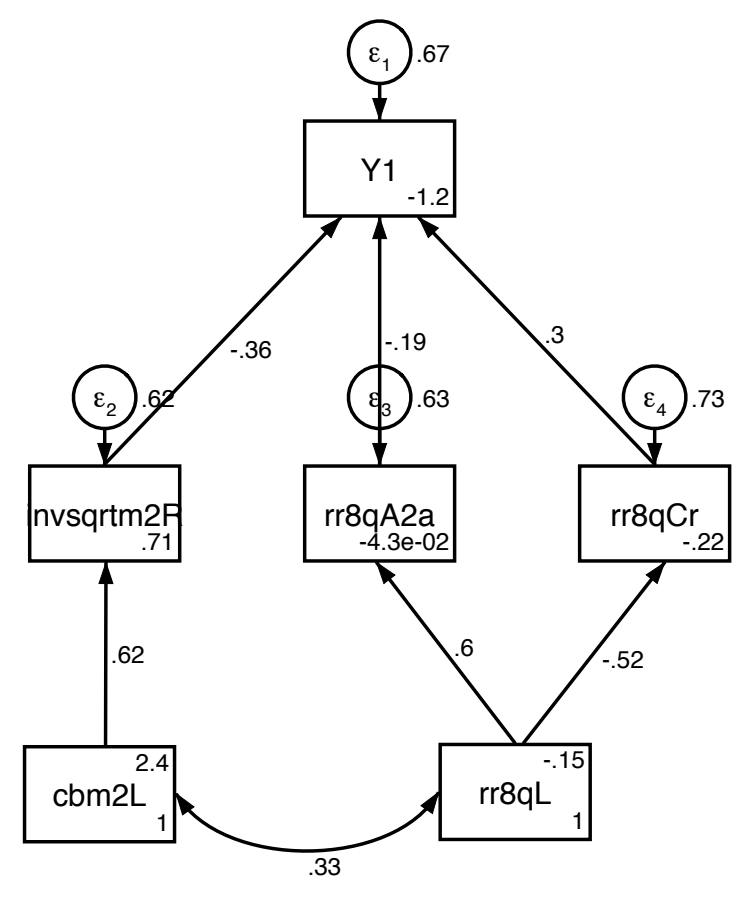


Table 4.1: This table shows Fit Indices for models constructed by Structural Equation Modeling Technique forecasting the percent change in stock market price between max- and min-point (Y1) and percent change in stock market price between averagemax- and average-min-point ( $\mathrm{Y} 2)$ based on varying lags (4, 8, and 12 quarters lags) of firms' characteristics variables at level of significance 0.05 . This set of models shares the same hypothetical view of the relationships between these variables as discussed in SEM1 models.

\begin{tabular}{lcccccc}
\hline & \multicolumn{3}{c}{ DV=Y1 } & & \multicolumn{3}{c}{ DV=Y2 } \\
\hline Fit Indices & $\begin{array}{c}\text { SEM1- } \\
\text { 4QY1 }\end{array}$ & SEM1- & SEM1- & SEM1- & SEM1- & SEM1- \\
& $8 Q Y 1$ & $12 Q Y 1$ & $4 Q Y 2$ & $8 Q Y 2$ & $12 Q Y 2$ \\
$X^{2}$ & 9.85 & 8.49 & 25.2 & 2.98 & 3.32 & 19.8 \\
P-value & 0.079 & 0.131 & 0.000 & 0.702 & 0.650 & 0.001 \\
RMSEA & 0.137 & 0.116 & 0.279 & 0.000 & 0.000 & 0.239 \\
Pclose & 0.12 & 0.185 & 0.000 & 0.757 & 0.711 & 0.003 \\
AIC & 234 & 189 & 248 & 243 & 200 & 254 \\
BIC & 264 & 218 & 278 & 273 & 229 & 284 \\
CFI & 0.915 & 0.939 & 0.63 & 1.00 & 1.00 & 0.67 \\
TLI & 0.847 & 0.891 & 0.34 & 1.00 & 1.07 & 0.409 \\
CD & 0.52 & 0.54 & 0.41 & 0.52 & 0.54 & 0.41 \\
\hline
\end{tabular}


Table 4.2: This table shows Fit Indices for models constructed by Structural Equation Modeling Technique forecasting the percent change in stock market price between max- and min-point (Y1) and percent change in stock market price between averagemax- and average-min-point (Y2) based on varying lags (4, 8, and 12 quarters lags) of firms' characteristics variables at level of significance 0.05 . This set of models shares the same hypothetical view of the relationships between these variables as discussed in SEM2 models.

\begin{tabular}{lllllll}
\hline & \multicolumn{3}{c}{ DV=Y1 } & & \multicolumn{2}{c}{ DV=Y2 } \\
\hline Fit Indices & SEM2- & SEM2- & SEM2- & SEM2- & SEM2- & SEM2- \\
& $4 Q Y 1$ & $8 Q Y 1$ & $12 Q Y 1$ & $4 Q Y 2$ & $8 Q Y 2$ & $12 Q Y 2$ \\
$X^{2}$ & 12.79 & 9.78 & 29.8 & 7.22 & 6.21 & 25.6 \\
P-value & 0.077 & 0.201 & 0.000 & 0.406 & 0.515 & 0.001 \\
RMSEA & 0.126 & 0.088 & 0.251 & 0.025 & 0.000 & 0.226 \\
Pclose & 0.124 & 0.278 & 0.000 & 0.496 & 0.601 & 0.002 \\
AIC & 418 & 371 & 432 & 427 & 384 & 440 \\
BIC & 457 & 410 & 471 & 466 & 423 & 479 \\
CFI & 0.909 & 0.956 & 0.647 & 0.996 & 1.00 & 0.656 \\
TLI & 0.843 & 0.925 & 0.394 & 0.992 & 1.028 & 0.410 \\
CD & 0.58 & 0.61 & 0.51 & 0.58 & 0.60 & 0.49 \\
\hline
\end{tabular}


Table 4.3: This table shows Fit Indices for models constructed by Structural Equation Modeling Technique forecasting the percent change in stock market price between max- and min-point (Y1) and percent change in stock market price between averagemax- and average-min-point (Y2) based on varying lags (4, 8, and 12 quarters lags) of firms' characteristics variables at level of significance 0.05 . This set of models shares the same hypothetical view of the relationships between these variables as discussed in SEM3 models.

\begin{tabular}{lllllll}
\hline & \multicolumn{3}{c}{ DV=Y1 } & & \multicolumn{2}{c}{ DV=Y2 } \\
\hline Fit Indices & SEM3- & SEM3- & SEM3- & SEM3- & SEM3- & SEM3- \\
& $4 Q Y 1$ & $8 Q Y 1$ & $12 Q Y 1$ & $4 Q Y 2$ & $8 Q Y 2$ & $12 Q Y 2$ \\
$X^{2}$ & 10.6 & 8.96 & 24.92 & 4.18 & 3.43 & 21.04 \\
P-value & 0.221 & 0.345 & 0.002 & 0.840 & 0.904 & 0.007 \\
RMSEA & 0.080 & 0.048 & 0.202 & 0.000 & 0.000 & 0.177 \\
Pclose & 0.306 & 0.441 & 0.005 & 0.884 & 0.933 & 0.016 \\
AIC & 144 & 122 & 232 & 153 & 135 & 240 \\
BIC & 181 & 159 & 269 & 190 & 172 & 277 \\
CFI & 0.964 & 0.987 & 0.745 & 1.00 & 1.00 & 0.769 \\
TLI & 0.937 & 0.978 & 0.562 & 1.112 & 1.135 & 0.595 \\
CD & 0.647 & 0.677 & 0.562 & 0.647 & 0.672 & 0.56 \\
\hline
\end{tabular}


Table 4.4: This table shows the standardized coefficients for three models which present three different hypothetical views (SEM1, SEM2, and SEM3) that describe the expected relationships between financial ratios to predict the outcome. These three models regress the percent change in stock market price between the max- and minpoint (Y1) on financial institutions' characteristics (ATR: average level of asset turn over, rrCR: accumulated rate of change of current ratio, rrA2a: accumulated rate of change of short- and long-term investment assets, logA: natural log of total assets, Lev: average level of leverage ratio, and rrLev: accumulated rate of change of leverage ratio). All models regressed over 4 quarters lag by the use of Structural Equation Modeling Technique.

\begin{tabular}{|c|c|c|c|c|c|c|c|c|c|c|}
\hline & & SEM1-4 & & & SEN & $2-4 Q$ & & & EM3-4Q & \\
\hline $\begin{array}{l}\text { DV } \\
\text { IV }\end{array}$ & rrCR & ATR $^{-0.5}$ & $\mathrm{Y1}$ & rrCR & ATR $^{-0.5}$ & $\mathrm{Y1}$ & rrA2a & rrCR & $\mathrm{ATR}^{-0.5}$ & $\overline{Y 1}$ \\
\hline ATR $^{-0.5}$ & & & $\begin{array}{c}- \\
0.3866 \\
* * * \\
(0.108)\end{array}$ & & & $\begin{array}{c}- \\
0.2364 \\
(0.127)\end{array}$ & & & & $\begin{array}{c}- \\
0.3929 \\
* * * \\
(0.107)\end{array}$ \\
\hline $\mathrm{rrA} 2 \mathrm{a}$ & & & & & & & & & & $\begin{array}{c}- \\
0.1078 \\
(0.121)\end{array}$ \\
\hline $\mathrm{rrCR}$ & & & $\underset{* *}{0.3556}$ & & & $\underset{* *}{0.3021}$ & & & & $\underset{* *}{0.3186}$ \\
\hline & & & $(0.110)$ & & & $(0.112)$ & & & & $(0.118)$ \\
\hline $\log A$ & & & & & & $\begin{array}{c}- \\
\substack{* * \\
* *} \\
(0.128)\end{array}$ & & & & \\
\hline Lev $^{3}$ & & $\begin{array}{l}0.5837 \\
* * * \\
(0.091)\end{array}$ & & & $\begin{array}{l}\underset{* * *}{0.5837} \\
(0.091)\end{array}$ & & & & $\begin{array}{l}0.5837 \\
* * * \\
(0.091)\end{array}$ & \\
\hline rrLev & $\begin{array}{c}- \\
0.5266 \\
* * * \\
(0.101)\end{array}$ & & & $\begin{array}{c}- \\
0.5272 \\
* * * \\
(0.101)\end{array}$ & & & $\begin{array}{l}\underset{* * * *}{0.5767} \\
(0.093)\end{array}$ & $\begin{array}{c}- \\
0.5263 \\
(0.101)\end{array}$ & & \\
\hline Const. & $\begin{array}{c}- \\
0.0012\end{array}$ & $\underset{*}{0.6915}$ & $\underset{* *}{-}$ & $\begin{array}{c}- \\
0.0037\end{array}$ & $\underset{*}{0.6915}$ & $\begin{array}{c}0.850 \\
(0.828)\end{array}$ & $\begin{array}{c}- \\
0.0737\end{array}$ & $\overline{-}-\overline{0013}$ & $\underset{*}{0.6915}$ & $\underset{* *}{-}$ \\
\hline
\end{tabular}




\begin{tabular}{|c|c|c|c|c|c|c|c|}
\hline & $(0.119)$ & $\begin{array}{ll}(0.338) & (0.349)\end{array}$ & $(0.119)$ & $(0.338)$ & $(0.115) \quad(0.119)$ & $(0.338)$ & $(0.337)$ \\
\hline$x^{2}$ & & 0.0793 & & 0.0773 & & 0.2207 & \\
\hline
\end{tabular}

Note: ${ }^{*} p<0.05 ;{ }^{* \star} p<0.01 ;{ }^{* *} p<0.001$

Standard errors in parenthesis

Dependent Variables: the percent change in stock market price between max- and min-point (Y1) during the financial crisis from 2007q3 until 2009q1

Table 4.5: This table shows the standardized coefficients for three models which present three different hypothetical views (SEM1, SEM2, and SEM3) that describe the expected relationships between financial ratios to predict the outcome. These three models regress the percent change in stock market price between the max- and minpoint (Y1) on financial institutions' characteristics (ATR: average level of asset turn over, rrCR: accumulated rate of change of current ratio, rrA2a: accumulated rate of change of short- and long-term investment assets, logA: natural log of total assets, Lev: average level of leverage ratio, and rrLev: accumulated rate of change of leverage ratio). All models regressed over 8 quarters lag by the use of Structural Equation Modeling Technique.

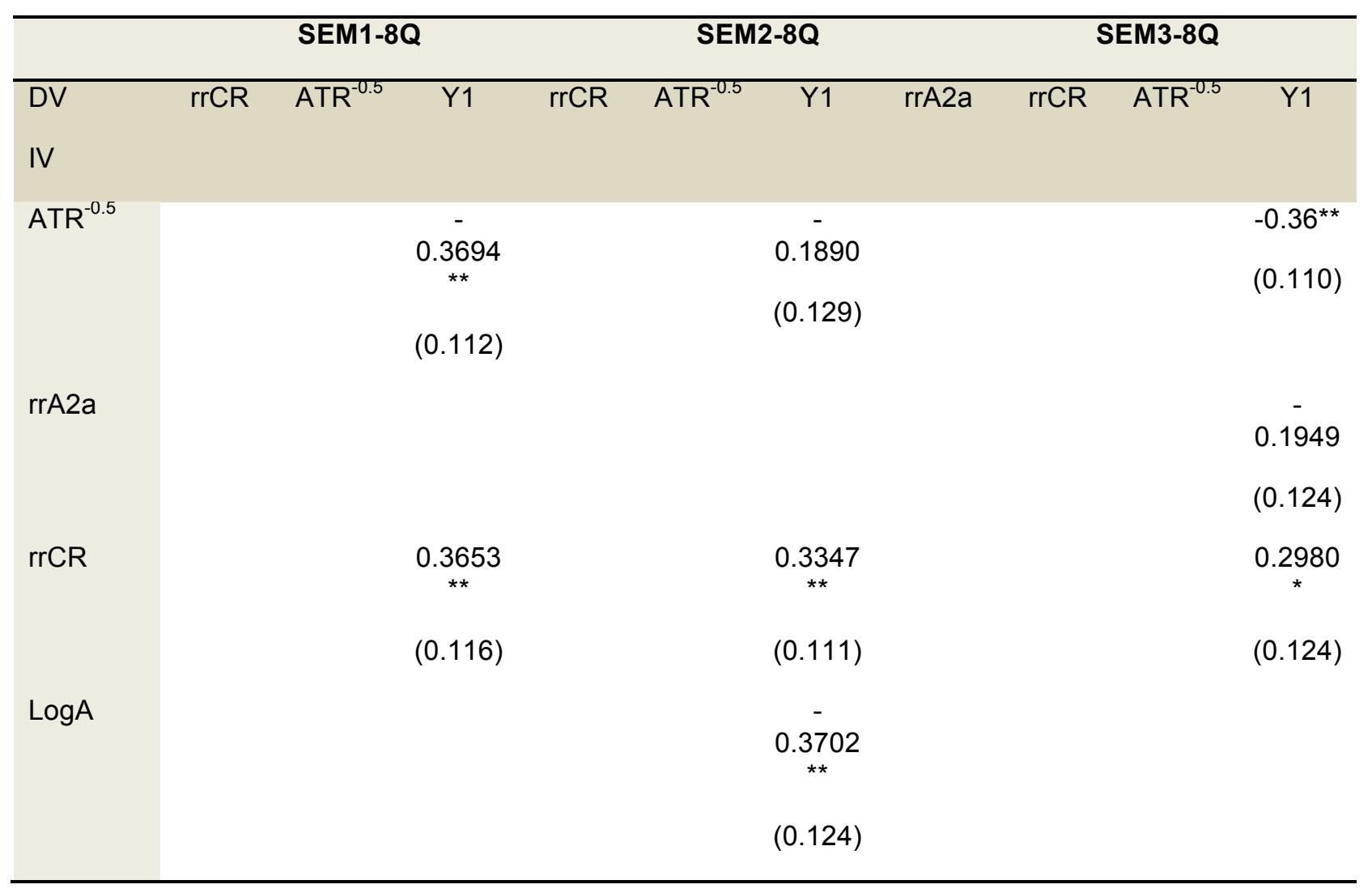




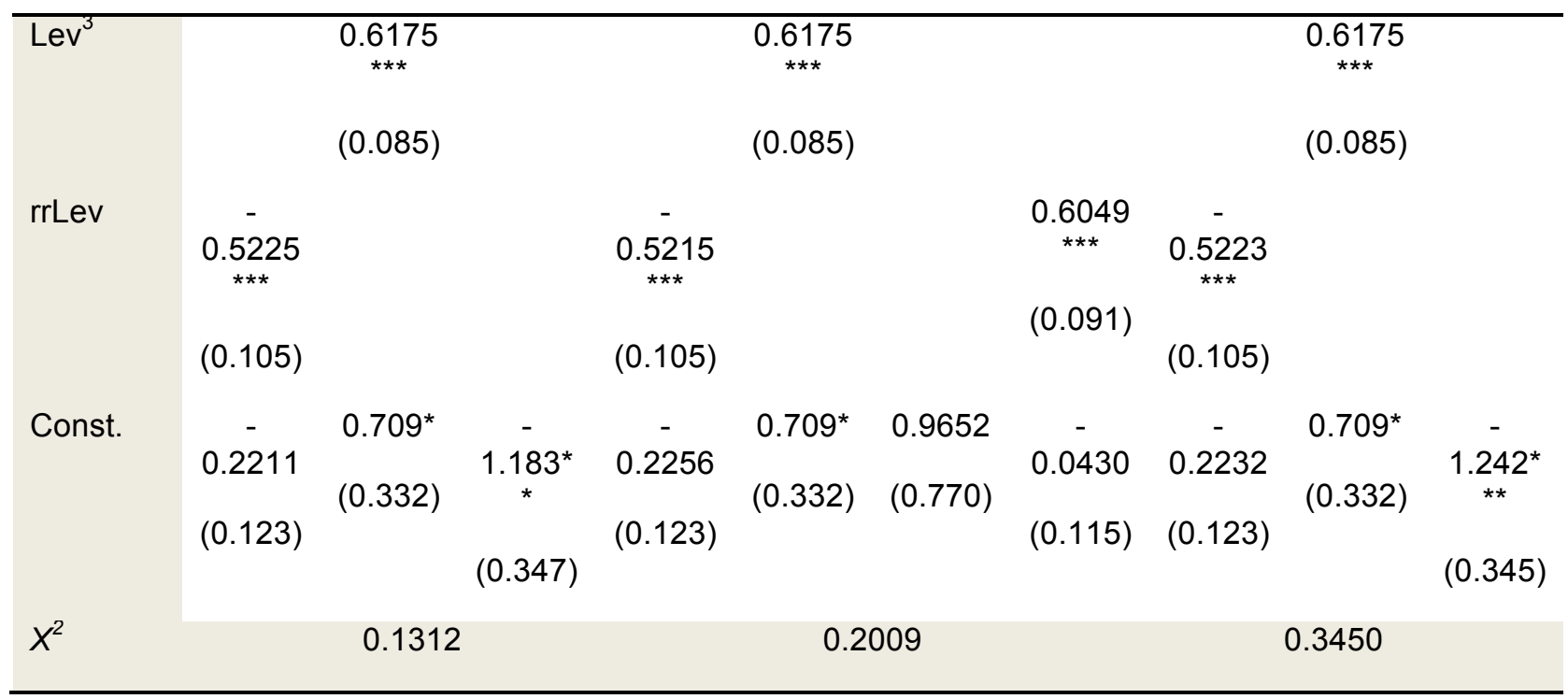

Note: ${ }^{*} p<0.05 ;{ }^{* *} p<0.01 ;{ }^{* *} p<0.001$

Standard errors in parenthesis

Dependent Variables: the percent change in stock market price between max- and min-point (Y1) during the financial crisis from 2007q3 until 2009q1

Table 4.6: This table shows the standardized coefficients for three models which present three different hypothetical views (SEM1, SEM2, and SEM3) that describe the expected relationships between financial ratios to predict the outcome. These three models regress the percent change in stock market price between the max- and minpoint (Y1) on financial institutions' characteristics (ATR: average level of asset turn over, rrCR: accumulated rate of change of current ratio, rrA2a: accumulated rate of change of short- and long-term investment assets, logA: natural log of total assets, Lev: average level of leverage ratio, and rrLev: accumulated rate of change of leverage ratio). All models regressed over 12 quarters lag by the use of Structural Equation Modeling Technique.

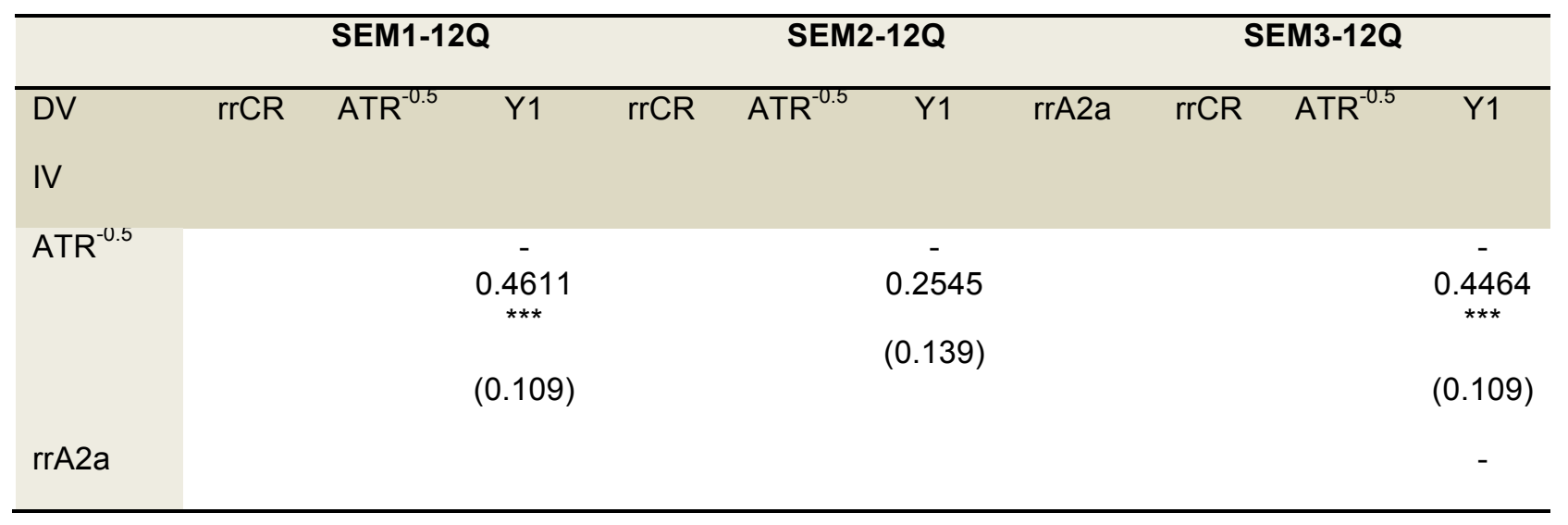




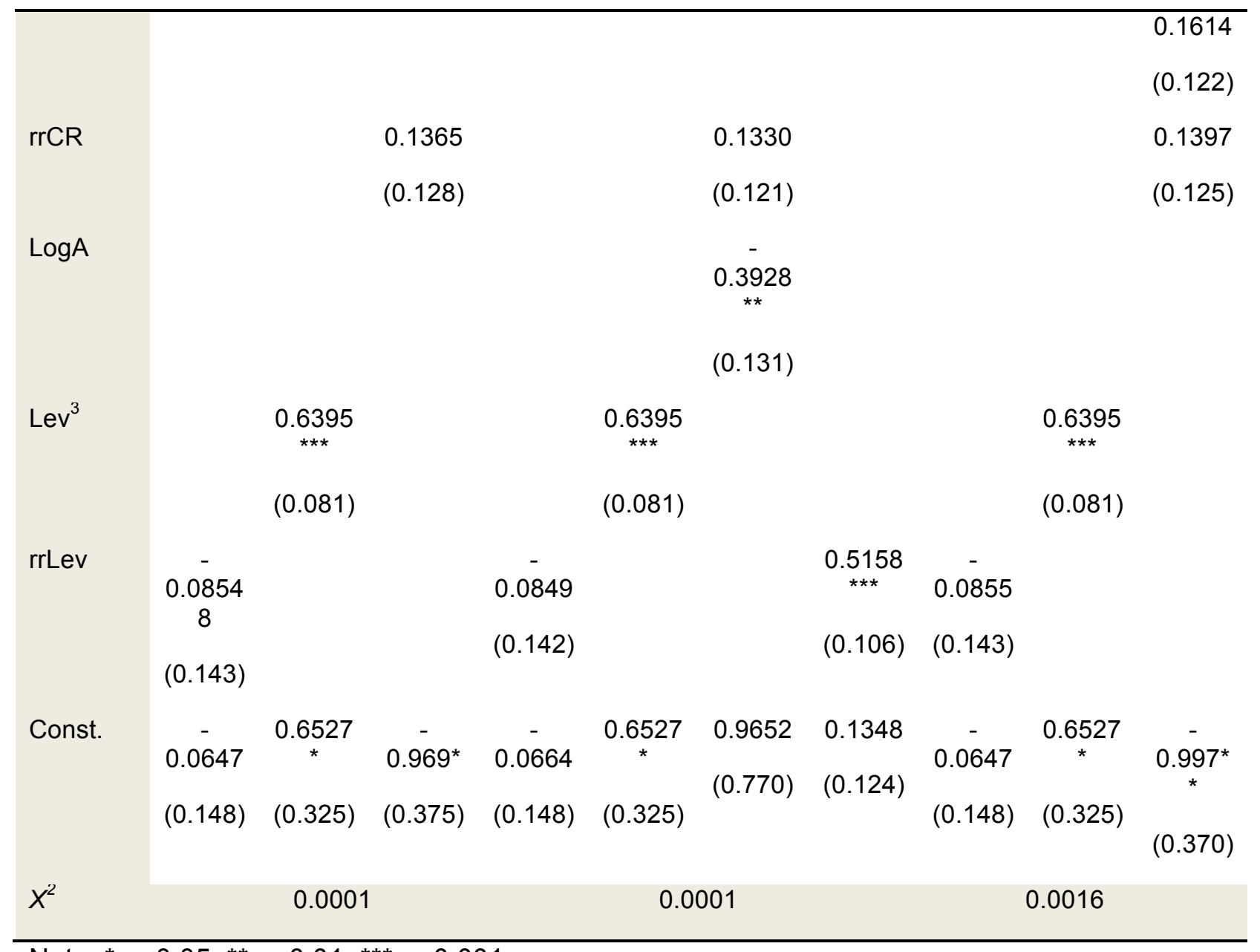

Note: * $p<0.05 ;{ }^{* *} p<0.01 ;{ }^{* * *} p<0.001$

Standard errors in parenthesis

Dependent Variables: the percent change in stock market price between max- and min-point (Y1) during the financial crisis from 2007q3 until 2009q1 
Table 4.7: This table shows the standardized coefficients for three models which present three different hypothetical views (SEM1, SEM2, and SEM3) that describe the expected relationships between financial ratios to predict the outcome. These three models regress the percent change in stock market price between average-max- and average-min-point (Y2) on financial institutions' characteristics (ATR: average level of asset turn over, rrCR: accumulated rate of change of current ratio, rrA2a: accumulated rate of change of short- and long-term investment assets, logA: natural log of total assets, Lev: average level of leverage ratio, and rrLev: accumulated rate of change of leverage ratio). All models regressed over 4 quarters lag by the use of Structural Equation Modeling Technique.

\begin{tabular}{|c|c|c|c|c|c|c|c|c|c|c|}
\hline & \multicolumn{4}{|c|}{ SEM1-4Q } & \multicolumn{3}{|c|}{ SEM2-4Q } & \multicolumn{3}{|c|}{ SEM3-4Q } \\
\hline $\begin{array}{l}\text { DV } \\
\text { IV }\end{array}$ & $\mathrm{rrCR}$ & $\mathrm{ATR}^{-0.5}$ & $\mathrm{Y} 2$ & $\mathrm{rrCR}$ & $\mathrm{ATR}^{-0.5}$ & $\bar{Y} 2$ & rrA2a & rrCR & $\operatorname{ATR}^{-0.5}$ & $\bar{Y} 2$ \\
\hline ATR $^{-0.5}$ & & & $\begin{array}{c}- \\
0.3193 \\
* * \\
(0.119)\end{array}$ & & & $\begin{array}{c}- \\
0.1627 \\
(0.138)\end{array}$ & & & & $\begin{array}{c}- \\
0.3221 \\
* * \\
(0.119)\end{array}$ \\
\hline $\mathrm{rrA} 2 \mathrm{a}$ & & & & & & & & & & $\begin{array}{c}- \\
0.0447 \\
(0.132)\end{array}$ \\
\hline $\mathrm{rrCR}$ & & & $\begin{array}{c}0.2577 \\
* \\
(0.121)\end{array}$ & & & $\begin{array}{l}0.1988 \\
(0.123)\end{array}$ & & & & $\begin{array}{l}0.2426 \\
(0.130)\end{array}$ \\
\hline $\log A$ & & & & & & $\begin{array}{c}- \\
0.345^{*} \\
(0.136)\end{array}$ & & & & \\
\hline $\operatorname{Lev}^{3}$ & & $\begin{array}{l}0.5837 \\
* * * \\
(0.091)\end{array}$ & & & $\begin{array}{l}0.5837 \\
* * * \\
(0.091)\end{array}$ & & & & $\begin{array}{l}0.5837 \\
* * * \\
(0.091)\end{array}$ & \\
\hline rrLev & $\begin{array}{c}- \\
\underset{* *}{526^{*}} \\
(0.101)\end{array}$ & & & $\begin{array}{c}- \\
\underset{* *}{*} \\
(0.101)\end{array}$ & & & $\begin{array}{l}\underset{* *}{0.577^{*}} \\
(0.093)\end{array}$ & $\begin{array}{c}- \\
\substack{* *\\
} \\
(0.101)\end{array}$ & & \\
\hline Const. & $\begin{array}{c}- \\
0.0014 \\
(0.119)\end{array}$ & $\begin{array}{c}0.6915 \\
* \\
(0.338)\end{array}$ & $\begin{array}{l}-0.78^{*} \\
(0.328)\end{array}$ & $\begin{array}{c}- \\
0.0037 \\
(0.119)\end{array}$ & $\begin{array}{c}0.6915 \\
* \\
(0.338)\end{array}$ & $\begin{array}{l}1.3419 \\
(0.874)\end{array}$ & $\begin{array}{c}- \\
0.0734 \\
(0.115)\end{array}$ & $\begin{array}{c}- \\
0.0014 \\
(0.119)\end{array}$ & $\begin{array}{c}0.6915 \\
* \\
(0.338)\end{array}$ & $\begin{array}{c}- \\
0.7768 \\
(0.327)\end{array}$ \\
\hline
\end{tabular}




\begin{tabular}{|c|c|c|c|}
\hline $\bar{X}^{2}$ & 0.7021 & 0.4062 & 0.8398 \\
\hline
\end{tabular}

Note: ${ }^{*} p<0.05 ;{ }^{* *} p<0.01 ;{ }^{* *} p<0.001$

Standard errors in parenthesis

Dependent Variables: the percent change in stock market price between average-max- and average-min-point (Y2) during the financial crisis from 2007q3 until 2009q1

Table 4.8: This table shows the standardized coefficients for three models which present three different hypothetical views (SEM1, SEM2, and SEM3) that describe the expected relationships between financial ratios to predict the outcome. These three models regress the percent change in stock market price between average-max- and average-min-point (Y2) on financial institutions' characteristics (ATR: average level of asset turn over, rrCR: accumulated rate of change of current ratio, rrA2a: accumulated rate of change of short- and long-term investment assets, logA: natural $\log$ of total assets, Lev: average level of leverage ratio, and rLev: accumulated rate of change of leverage ratio). All models regressed over 8 quarters lag by the use of Structural Equation Modeling Technique.

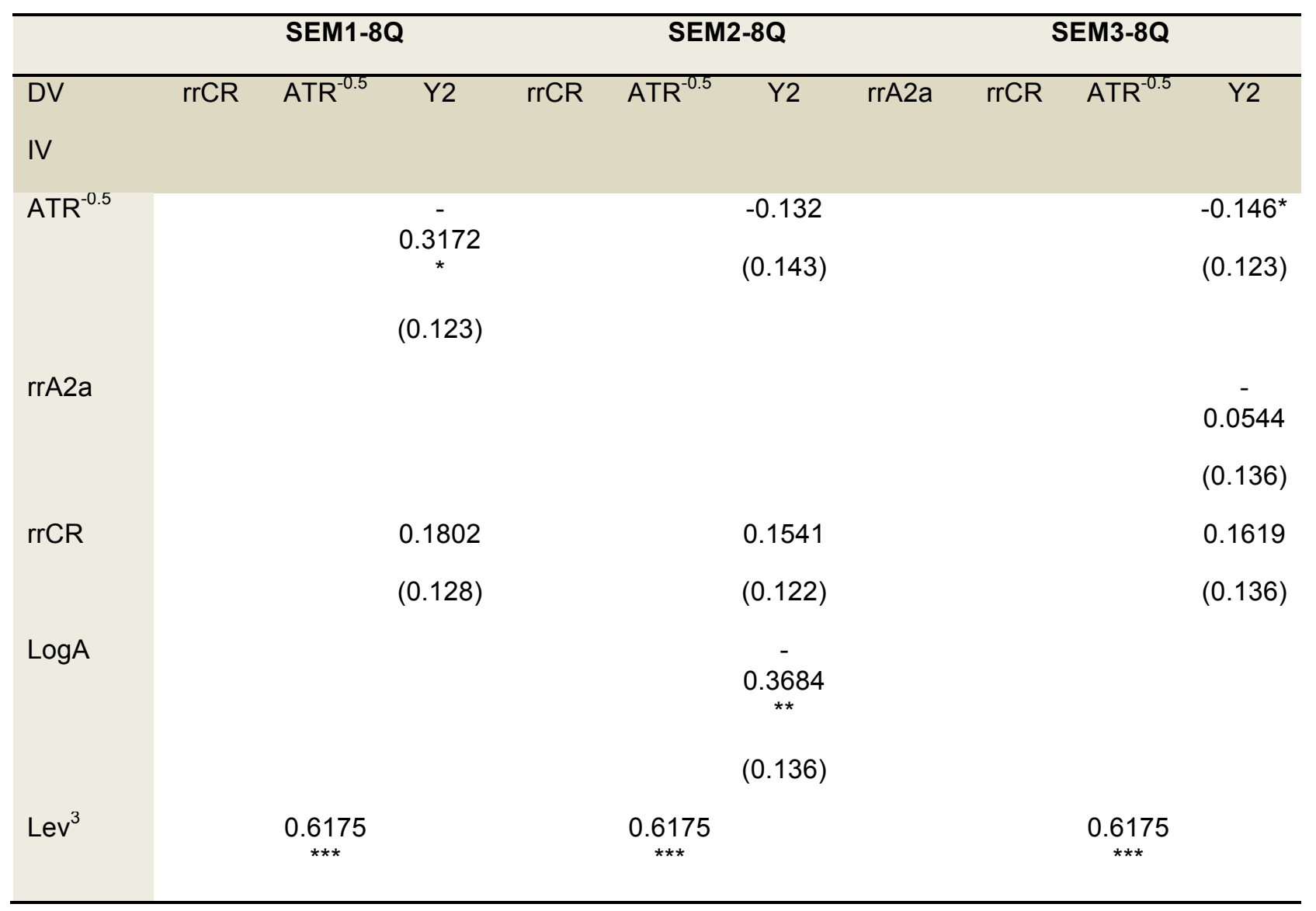




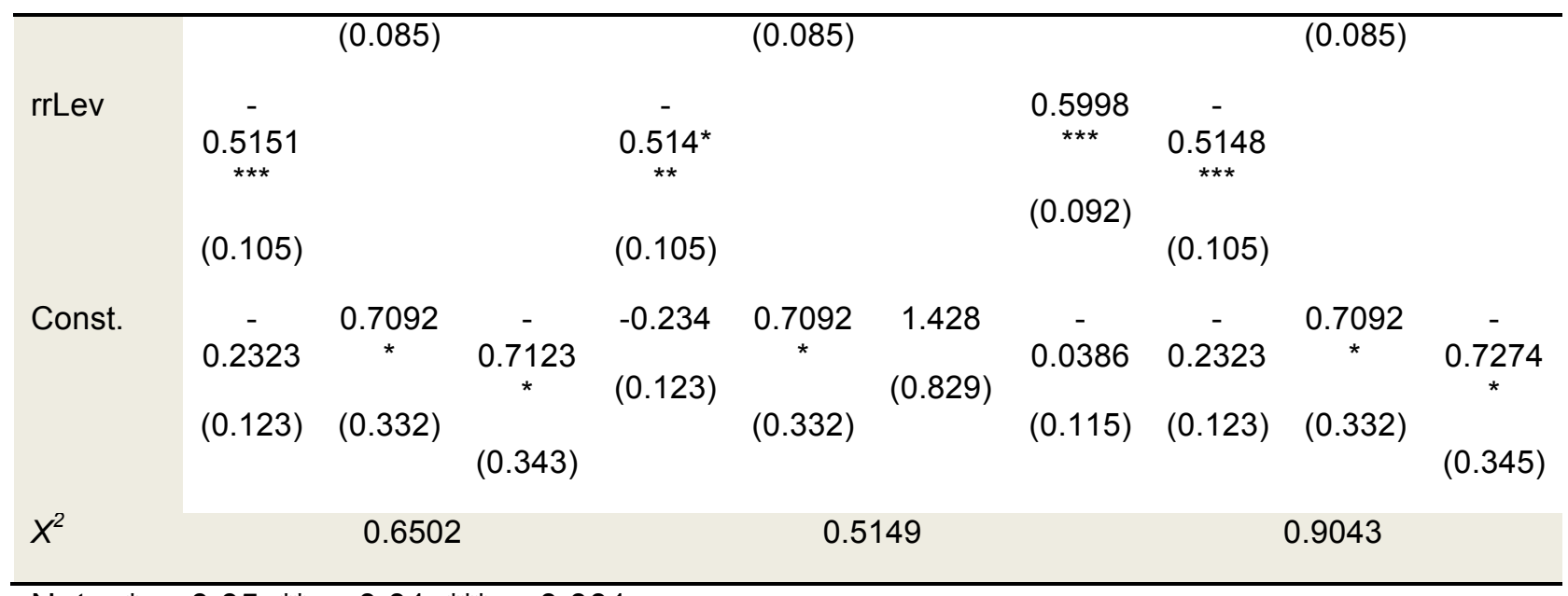

Note: ${ }^{*} p<0.05 ;{ }^{* *} p<0.01 ;{ }^{* * *} p<0.001$

Standard errors in parenthesis

Dependent Variables: the percent change in stock market price between average-max- and average-min-point (Y2) during the financial crisis from 2007q3 until 2009q1

Table 4.9: This table shows the standardized coefficients for three models which present three different hypothetical views (SEM1, SEM2, and SEM3) that describe the expected relationships between financial ratios to predict the outcome. These three models regress the percent change in stock market price between average-max- and average-min-point (Y2) on financial institutions' characteristics (ATR: average level of asset turn over, rrCR: accumulated rate of change of current ratio, rrA2a: accumulated rate of change of short- and long-term investment assets, $\log A$ : natural $\log$ of total assets, Lev: average level of leverage ratio, and rrLev: accumulated rate of change of leverage ratio). All models regressed over 12 quarters lag by the use of Structural Equation Modeling Technique.

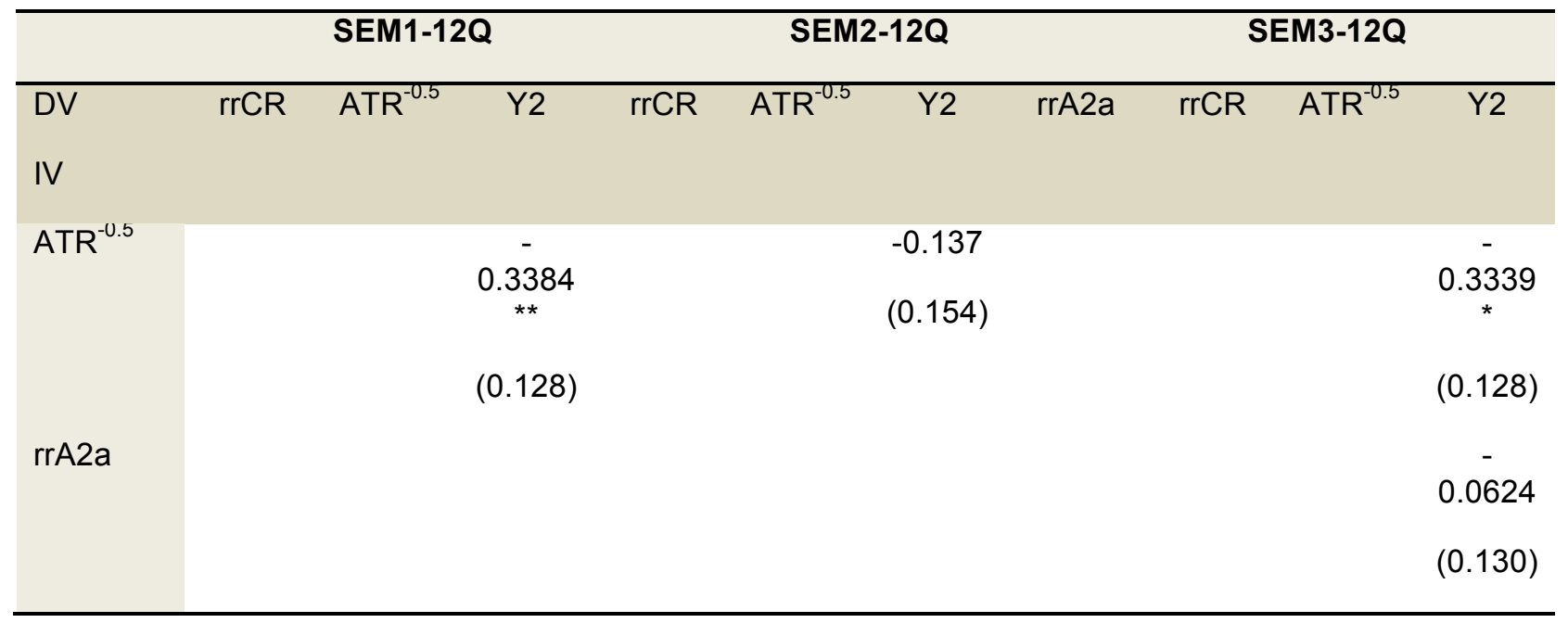




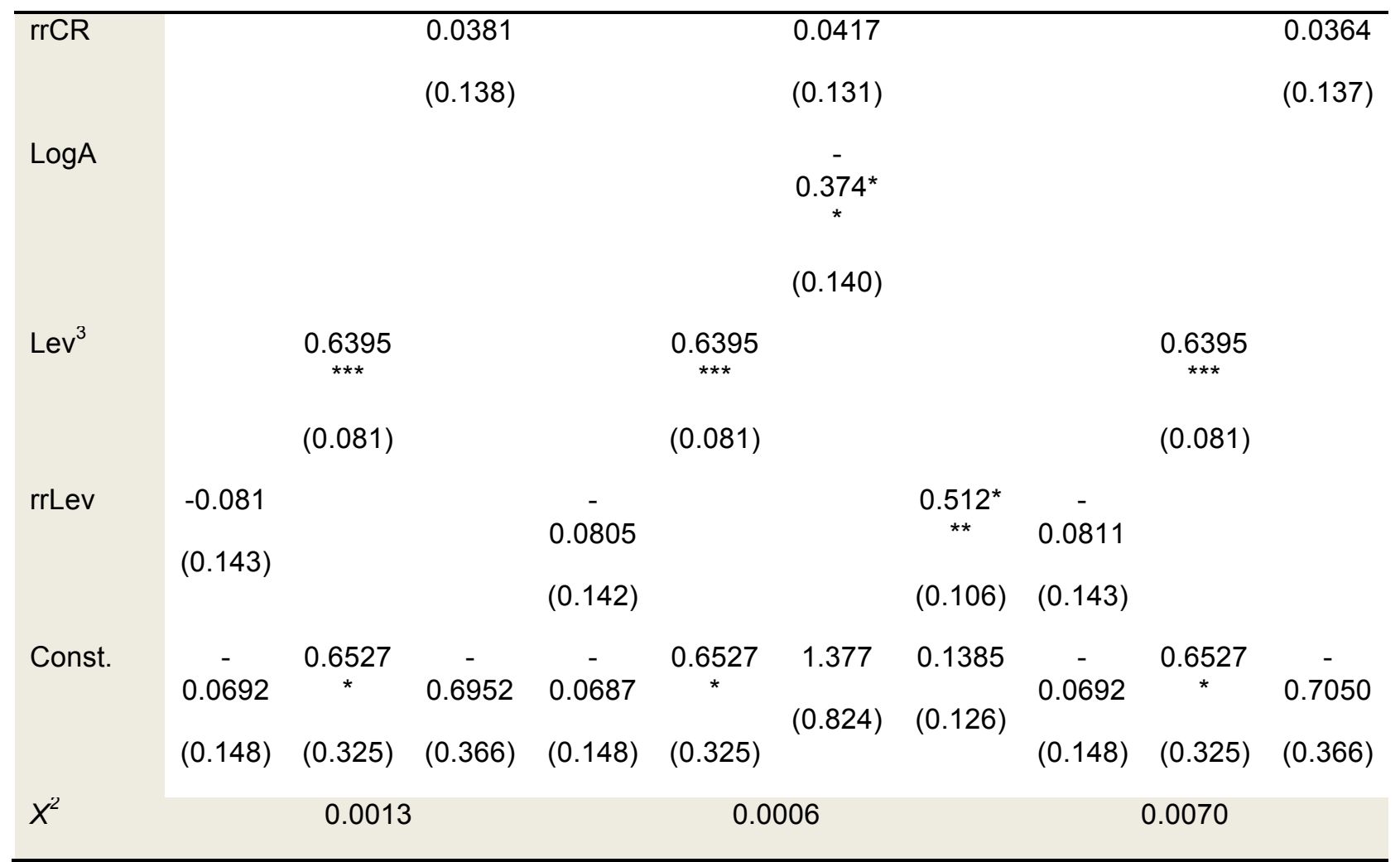

Note: ${ }^{*} p<0.05 ;{ }^{* *} p<0.01 ;{ }^{* *} p<0.001$

Standard errors in parenthesis

Dependent Variables: the percent change in stock market price between average-max- and average-min-point (Y2) during the financial crisis from 2007q3 until 2009q1 
Figure 4.4: Average Level of Asset Turnover Ratio versus Y1

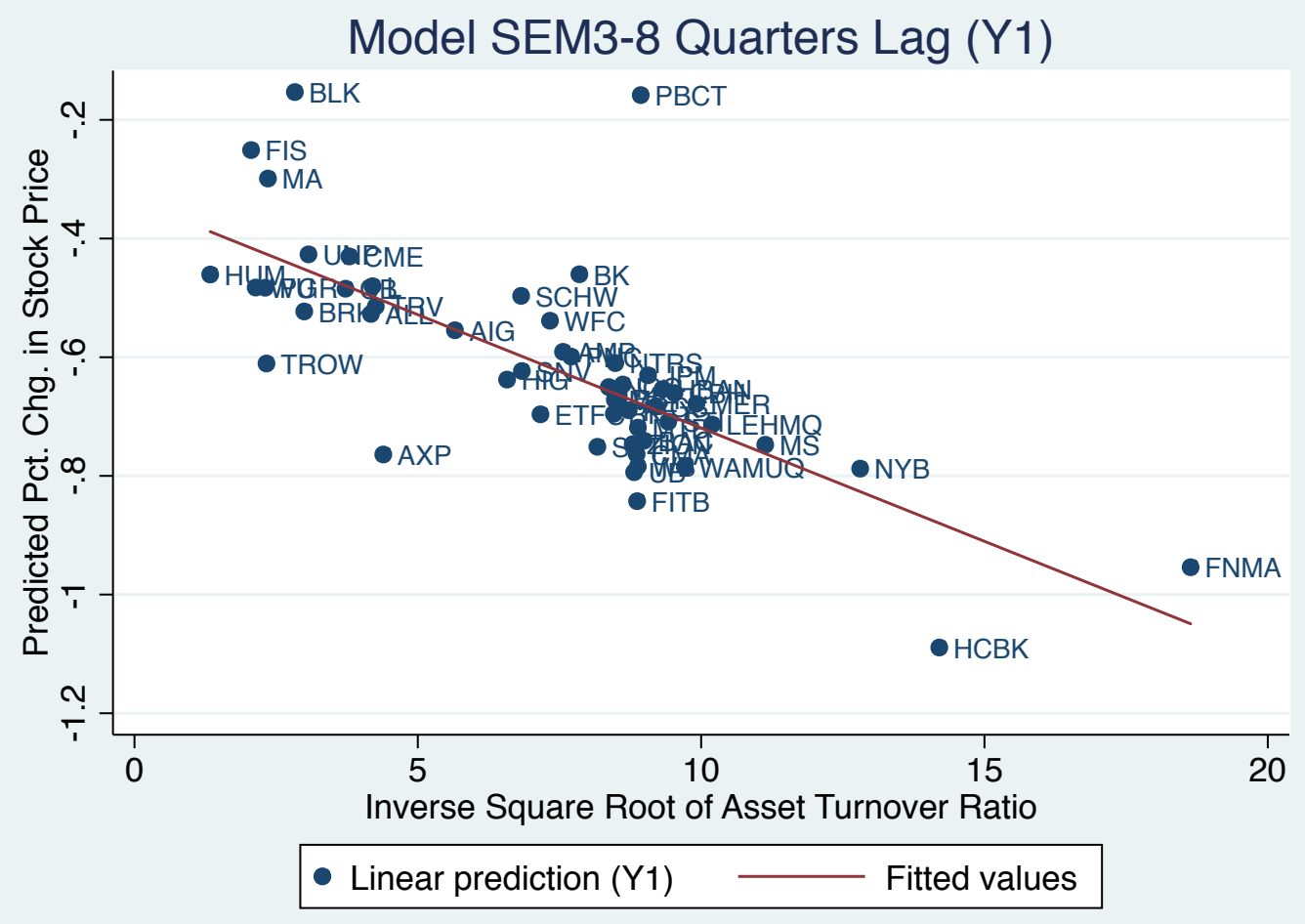

Figure 4.5: Accumulated Rate of Change of Short- and Long-term Investment Assets Ratio versus $Y 1$

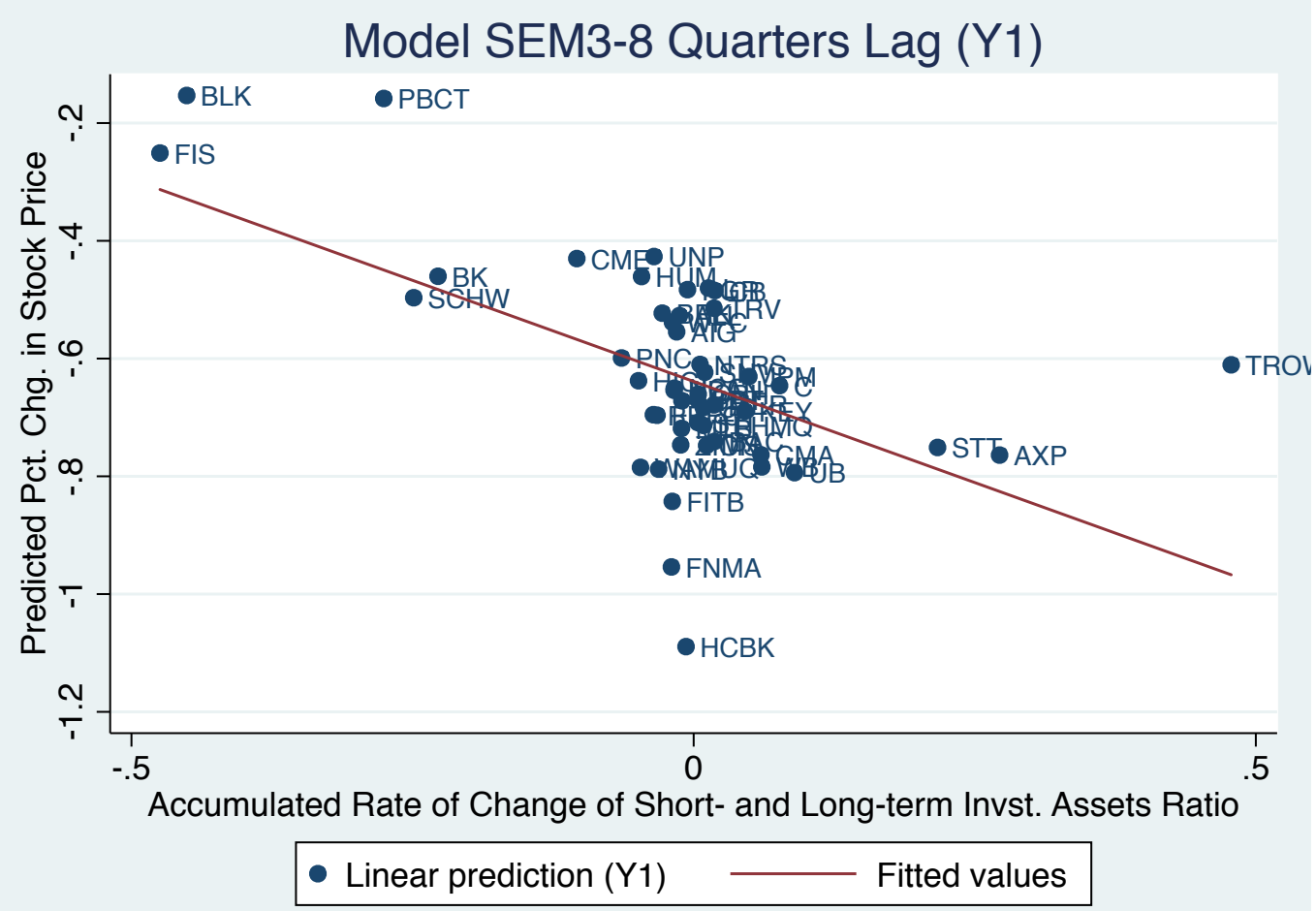


Figure 4.6: Accumulated Rate of Change of Current Ratio versus Y1

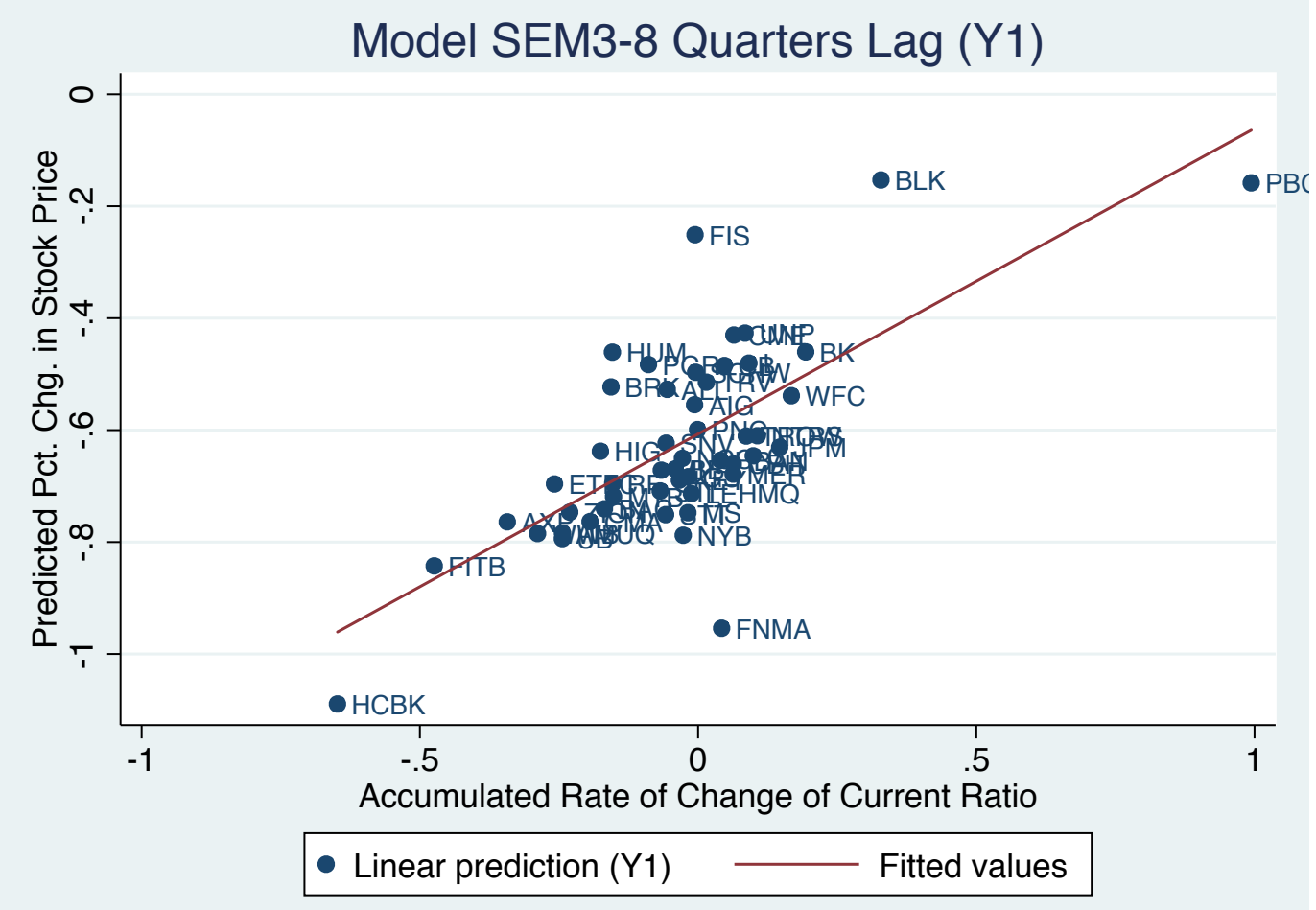

Figure 4.7: Average Level of Leverage Ratio versus Y1

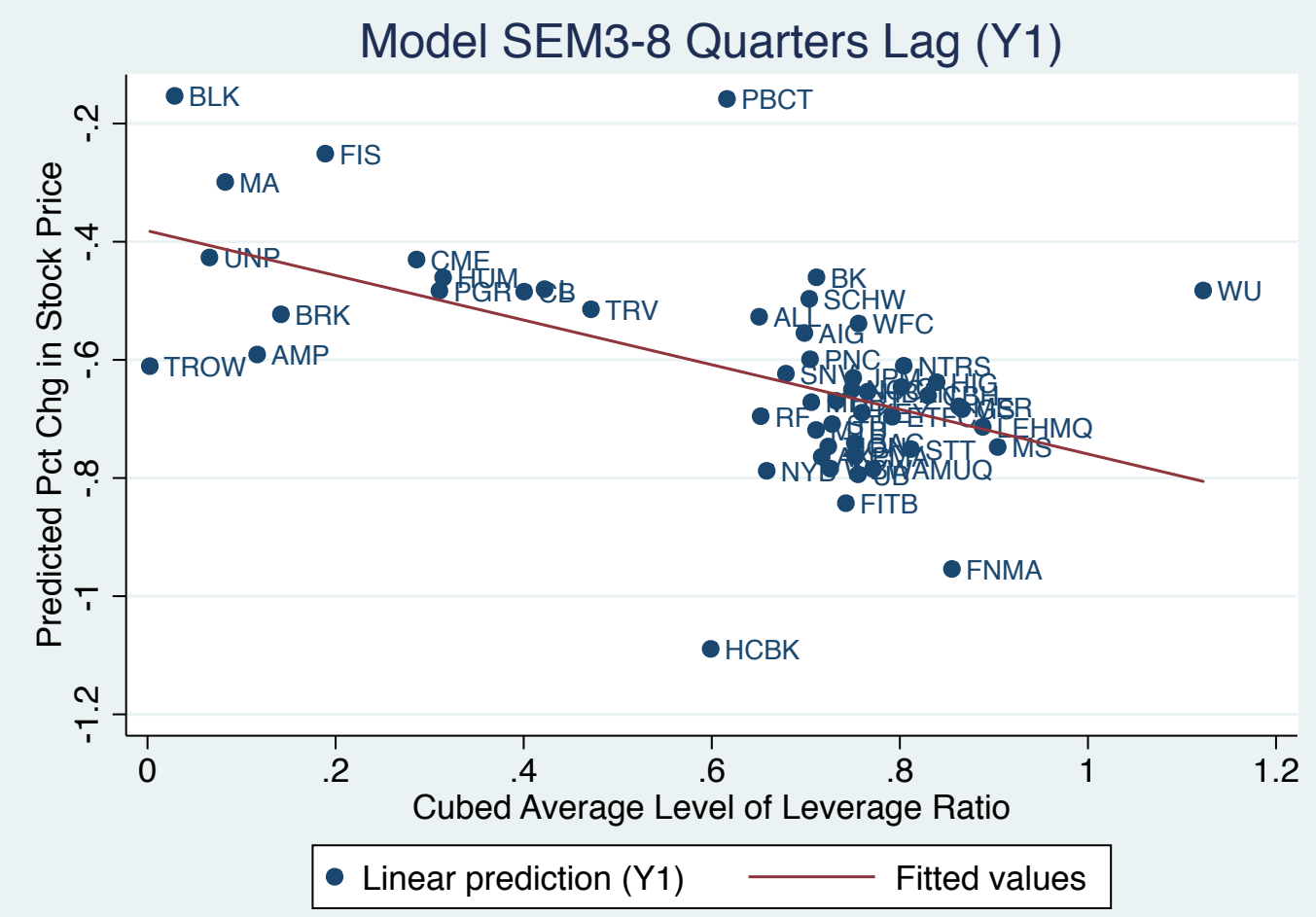


Figure 4.8: Accumulated Rate of Change of Leverage Ratio versus Y1

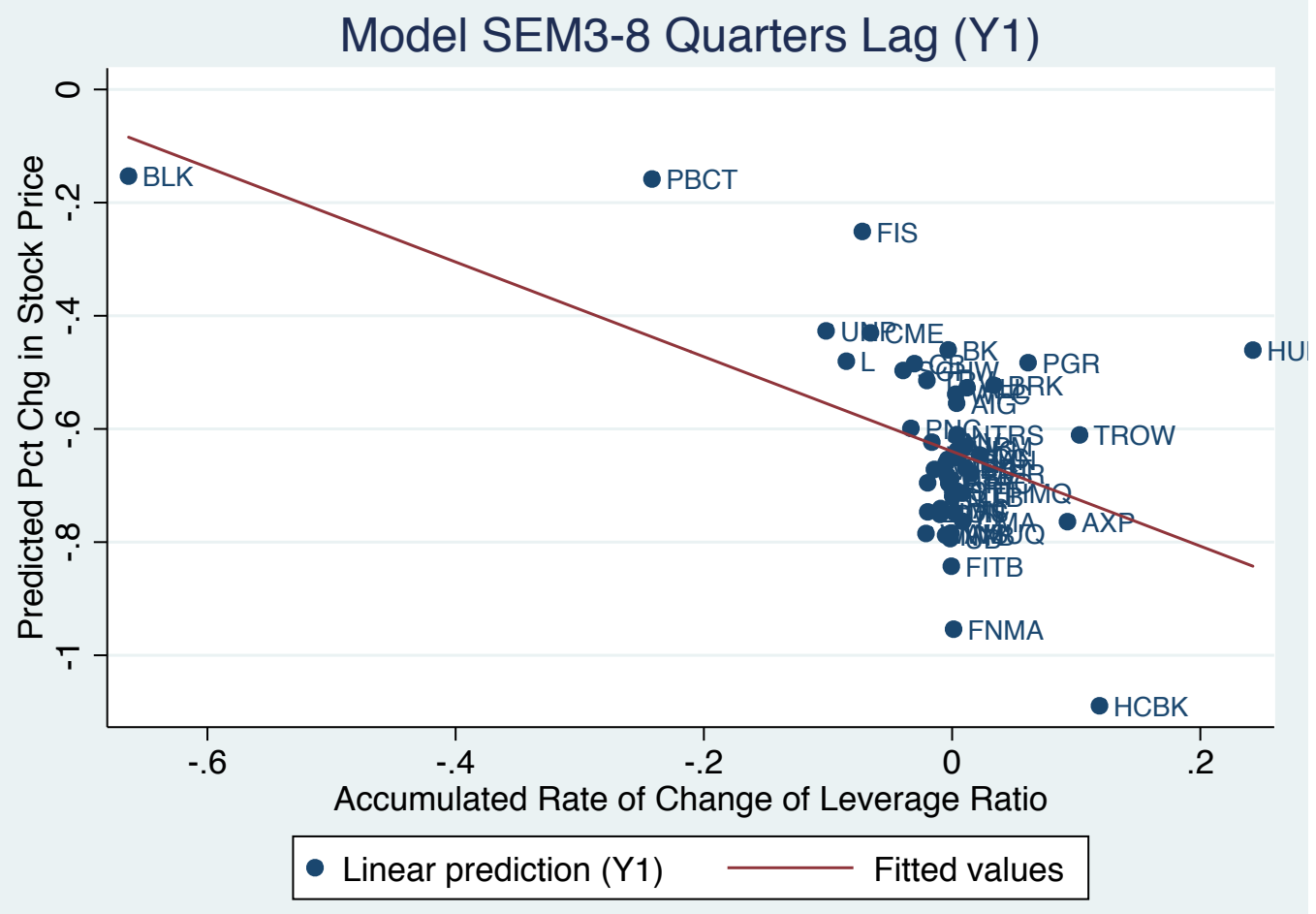


Table 4.10: This table shows mean levels of each predictor, their values at one standard deviation away from mean level in both directions, and the predicted change from the average in stock market price by model SEM3-8Q to predict $\mathrm{Y} 1$ accordingly.

\begin{tabular}{|c|c|c|}
\hline Predictor Variables & Values & Predicted $\% \Delta$ in Stock Price \\
\hline & $\begin{array}{l}(\mathrm{Lev})^{3} @ \text { mean }+1 \mathrm{SD}=0.886 \\
\text { Lev @ } 0.96(+12.38 \%)\end{array}$ & $-6.8 \%$ \\
\hline \multirow[t]{3}{*}{$\begin{array}{l}\text { Leverage Ratio: } \\
\text { (Total Debt / Total Capital) }\end{array}$} & $\begin{array}{l}(\text { Lev })^{3} @ \text { mean = } 0.6246 \\
\text { Lev @ } 0.854\end{array}$ & 0.0 \\
\hline & $\begin{array}{l}(\mathrm{Lev})^{3} @ \text { mean }-1 \mathrm{SD}=0.362 \\
\text { Lev @ } 0.713(-16.57 \%)\end{array}$ & $+6.8 \%$ \\
\hline & rrLev@ mean +1SD = 0.98 & $-8.26 \%$ \\
\hline \multirow{3}{*}{$\begin{array}{l}\text { Accumulated Rate of Change } \\
\text { of Leverage Ratio }\end{array}$} & rrLev @ mean = -0.014 & 0.0 \\
\hline & rrLev@ mean -1SD = -0.127 & $+8.26 \%$ \\
\hline & $\begin{array}{l}(\text { ATR })^{-0.5} @ \text { mean }+1 S D= \\
10.70 \\
\text { ATR @ } 0.0087(-53.07 \%)\end{array}$ & $-11.01 \%$ \\
\hline \multirow{5}{*}{$\begin{array}{l}\text { Asset Turnover Ratio } \\
\text { (Total Revenue / Average } \\
\text { Asset) }\end{array}$} & $(\mathrm{ATR})^{-0.5} @$ mean = 7.336 & 0.0 \\
\hline & ATR@ @ 0.0185 & \\
\hline & $\begin{array}{l}(\mathrm{ATR})^{-0.5} @ \text { mean -1SD = } \\
3.963\end{array}$ & $+11.016 \%$ \\
\hline & ATR @ 0.0636 (+242.6\%) & \\
\hline & rrCR @ mean +1SD = 0.19 & $9.18 \%$ \\
\hline \multirow{3}{*}{$\begin{array}{l}\text { Accumulated Rate of Change } \\
\text { of Current Ratio: }\end{array}$} & rrCR @ mean = -0.037 & 0.0 \\
\hline & rrCR @ mean -1SD = -0.264 & $-9.18 \%$ \\
\hline & rrA2a @ mean +1SD = 0.129 & $-5.81 \%$ \\
\hline \multirow{2}{*}{$\begin{array}{l}\text { Accumulated Rate of Change } \\
\text { of Short- and Long-term } \\
\text { Investment Assets Ratio }\end{array}$} & rrA2a@ mean = -0.016 & 0.0 \\
\hline & rrA2a @ mean -1SD = -0.161 & $+5.81 \%$ \\
\hline
\end{tabular}




\section{APPENDIX E}

Table 5.1: This table shows Fit Indices for Multivariable Fractional Polynomials Models 1 Through 6 predicting the percent change in stock market price between max- and min-point $(\mathrm{Y} 1)$ and percent change in stock market price between average-max- and average-min-point (Y2) during the systemic crisis in 2008.

\begin{tabular}{lllllllllll}
\hline Model & $\#$ & $R^{2}$ & $a R^{2}$ & Swilk & $\begin{array}{l}\text { Root } \\
\text { MSE }\end{array}$ & $\begin{array}{l}\text { F-stat } \\
p \text {-valu }\end{array}$ & $\begin{array}{l}\text { Im } p- \\
\text { value }\end{array}$ & $\begin{array}{l}\text { Het } p- \\
\text { valu }\end{array}$ & $\begin{array}{l}\text { Link } \\
p \text {-valu }\end{array}$ & $\begin{array}{l}\text { Ov } p-~ \\
\text { value }\end{array}$ \\
\hline MFP4QY1 & 1 & 0.21 & 0.20 & 0.005 & 0.26 & 0.0006 & 0.23 & 0.62 & 0.019 & 0.07 \\
MFP8QY1 & 2 & 0.52 & 0.49 & 0.260 & 0.20 & 0.0000 & 0.44 & 0.93 & 0.317 & 0.22 \\
MFP12QY1 & 3 & 0.21 & 0.19 & 0.009 & 0.27 & 0.0016 & 0.02 & 0.27 & 0.077 & 0.26 \\
MFP4QY2 & 4 & 0.11 & 0.09 & 0.21 & 0.29 & 0.0185 & 0.49 & 0.12 & 0.063 & 0.04 \\
MFP8QY2 & 5 & 0.11 & 0.09 & 0.28 & 0.29 & 0.02 & 0.52 & 0.15 & 0.055 & 0.07 \\
MFP12QY2 & 6 & 0.28 & 0.25 & 0.29 & 0.27 & 0.0011 & 0.43 & 0.80 & 0.483 & 0.86 \\
\hline
\end{tabular}


Table 5.2: This table reports the coefficients of regressing two measures of systemic effects (the percent change in stock market price between max- and min-point (Y1) and percent change in stock market price between average-max- and average-min-point (Y2)) on one-year, two-years, and three-years lagged financial institutions' ratios by using fractional polynomials regression technique at level of significance 0.05 .

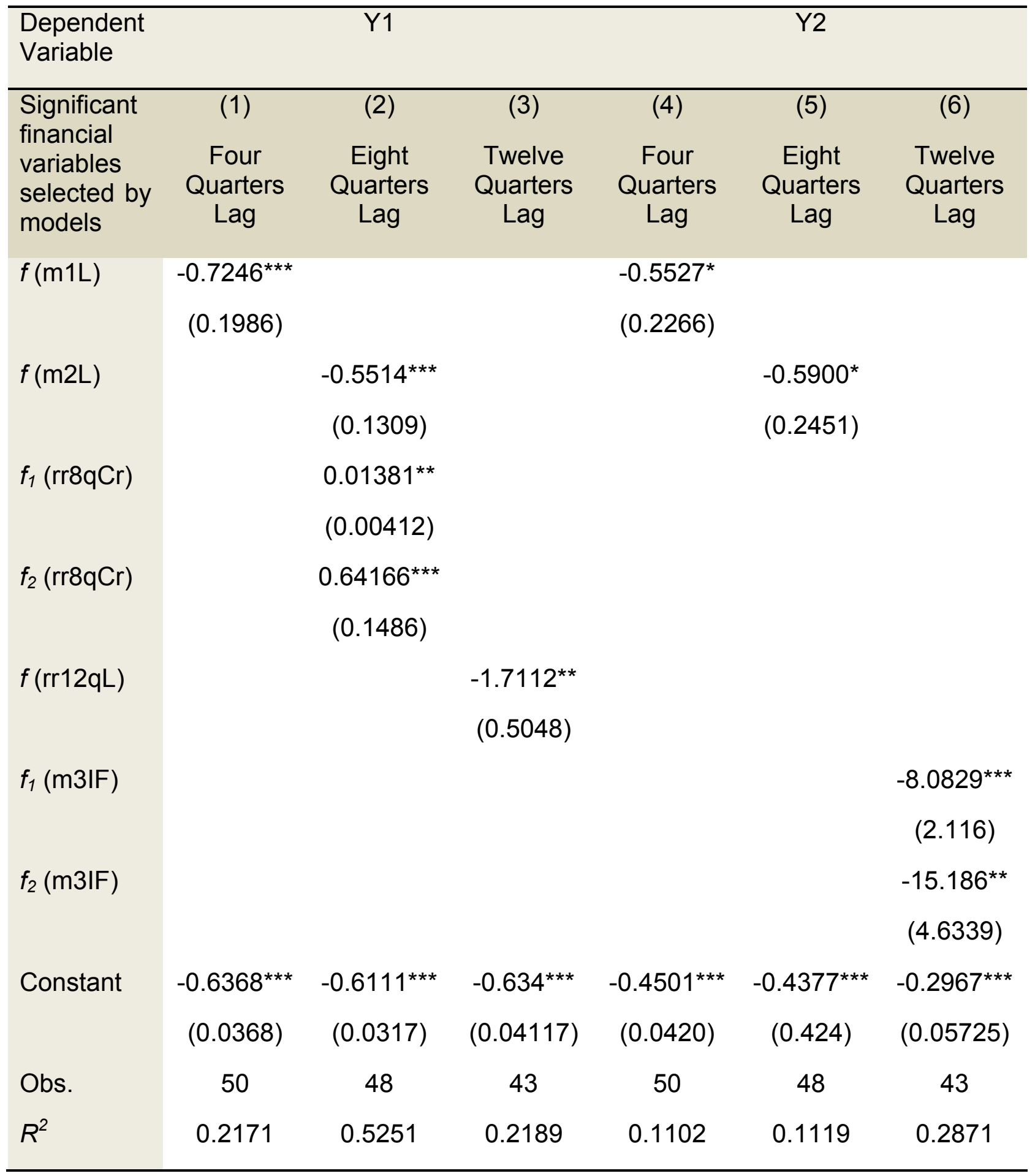




\begin{tabular}{lllllll}
\hline Adj. $R^{2}$ & 0.2008 & 0.4927 & 0.1998 & 0.0917 & 0.0926 & 0.2515
\end{tabular}

Note: ${ }^{*} p<0.05 ;{ }^{* *} p<0.01 ;{ }^{* * *} p<0.001$

Standard errors in parenthesis

Dependent Variables: the percent change in stock market price between max- and min-point (Y1) and percent change in stock market price between average-max- and average-min-point (Y2) during the financial crisis from 2007q3 until 2009q1.

Independent Variables: every model starts with the total of 17 independent variables over the same lag to end up with the selected significant variables as shown in the table above in the transformed forms as presented in each equation accordingly. 
Figure 5.1: Average Level of Leverage Ratio versus Y1

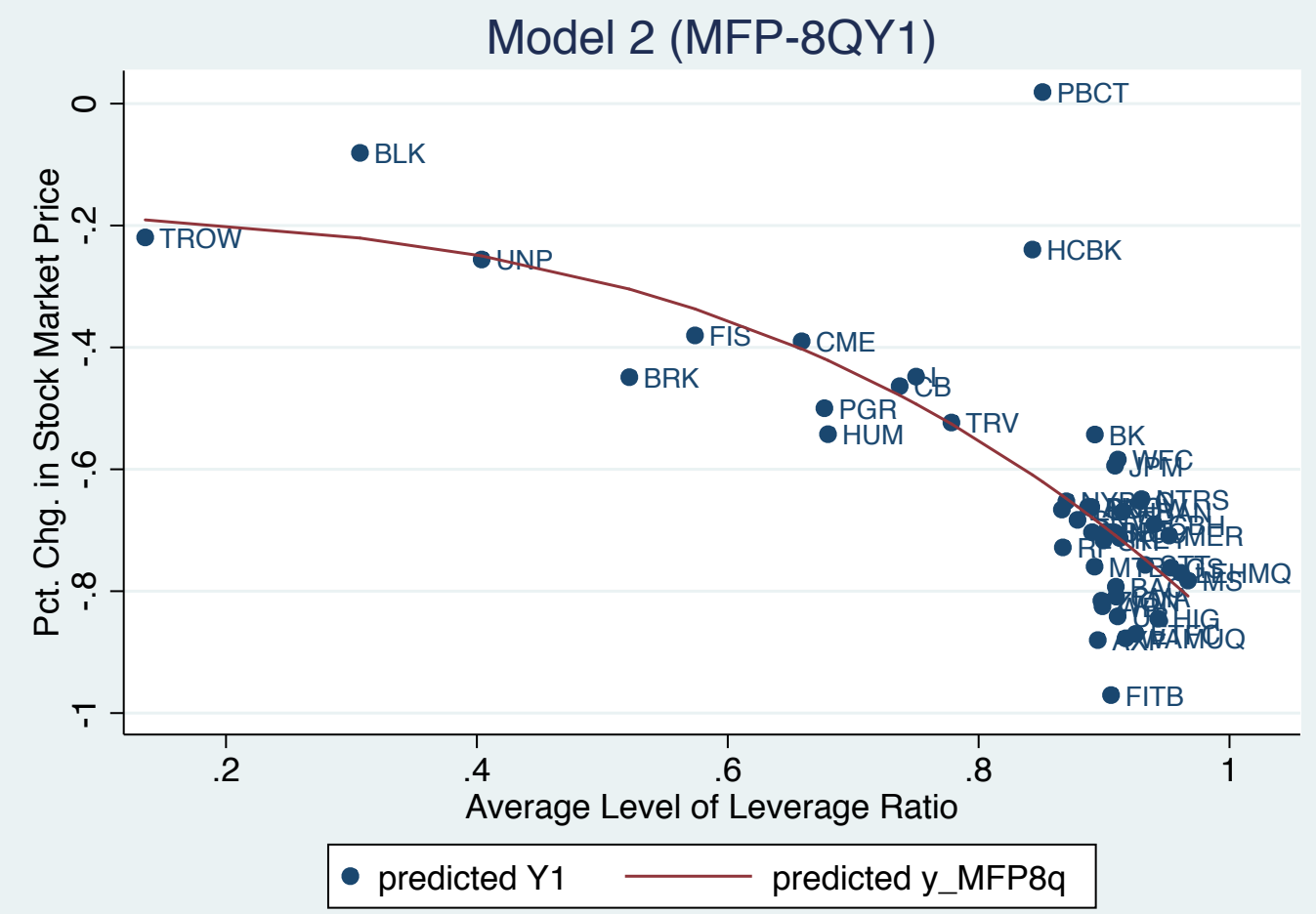

Figure 5.2: Accumulated Rate of Change of Current Ratio versus Y1

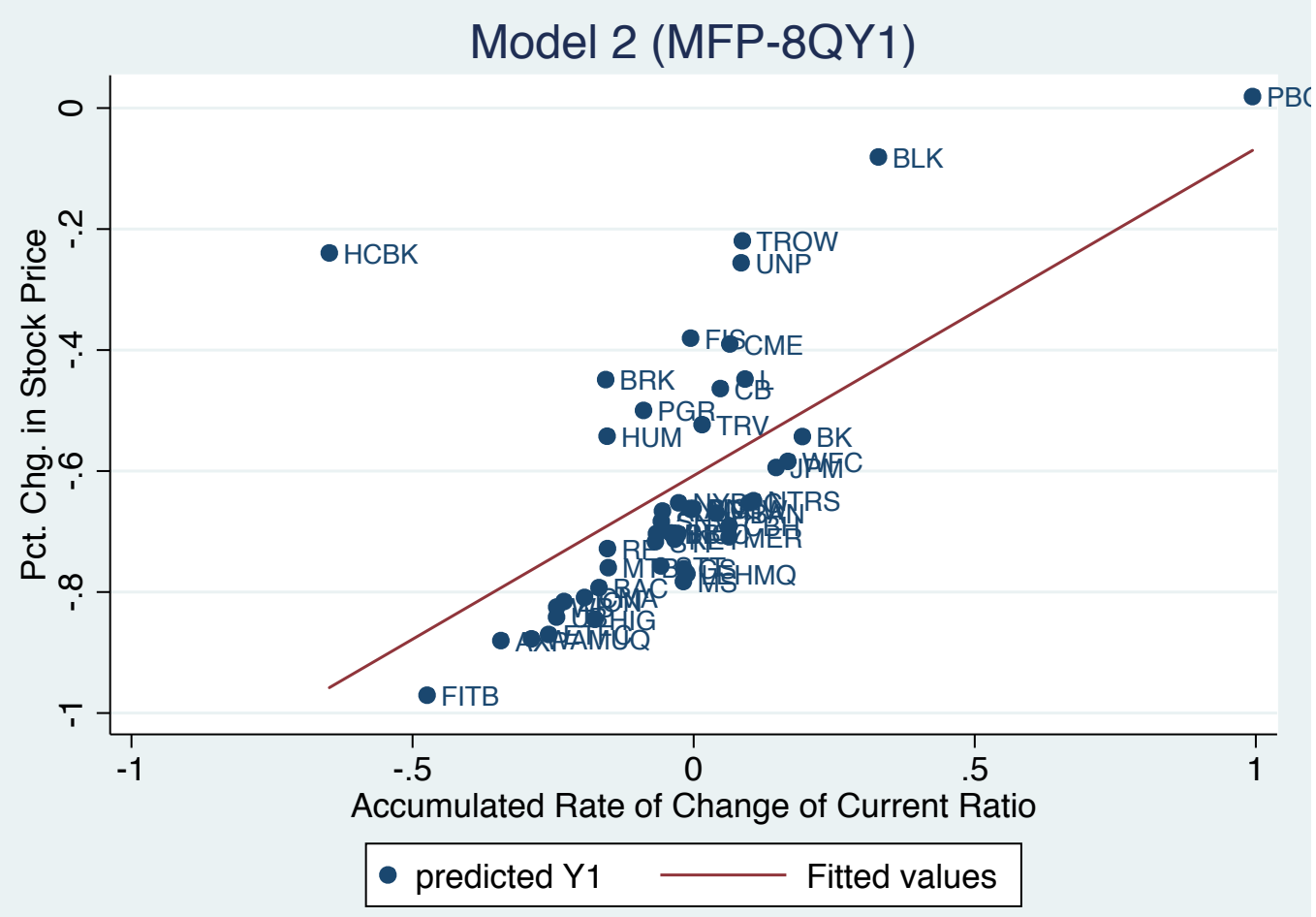


Figure 5.3: The predicted drops in stock market prices starting from the highest to the least according to Model 2 by the use of MFP Technique as of 2007Q2

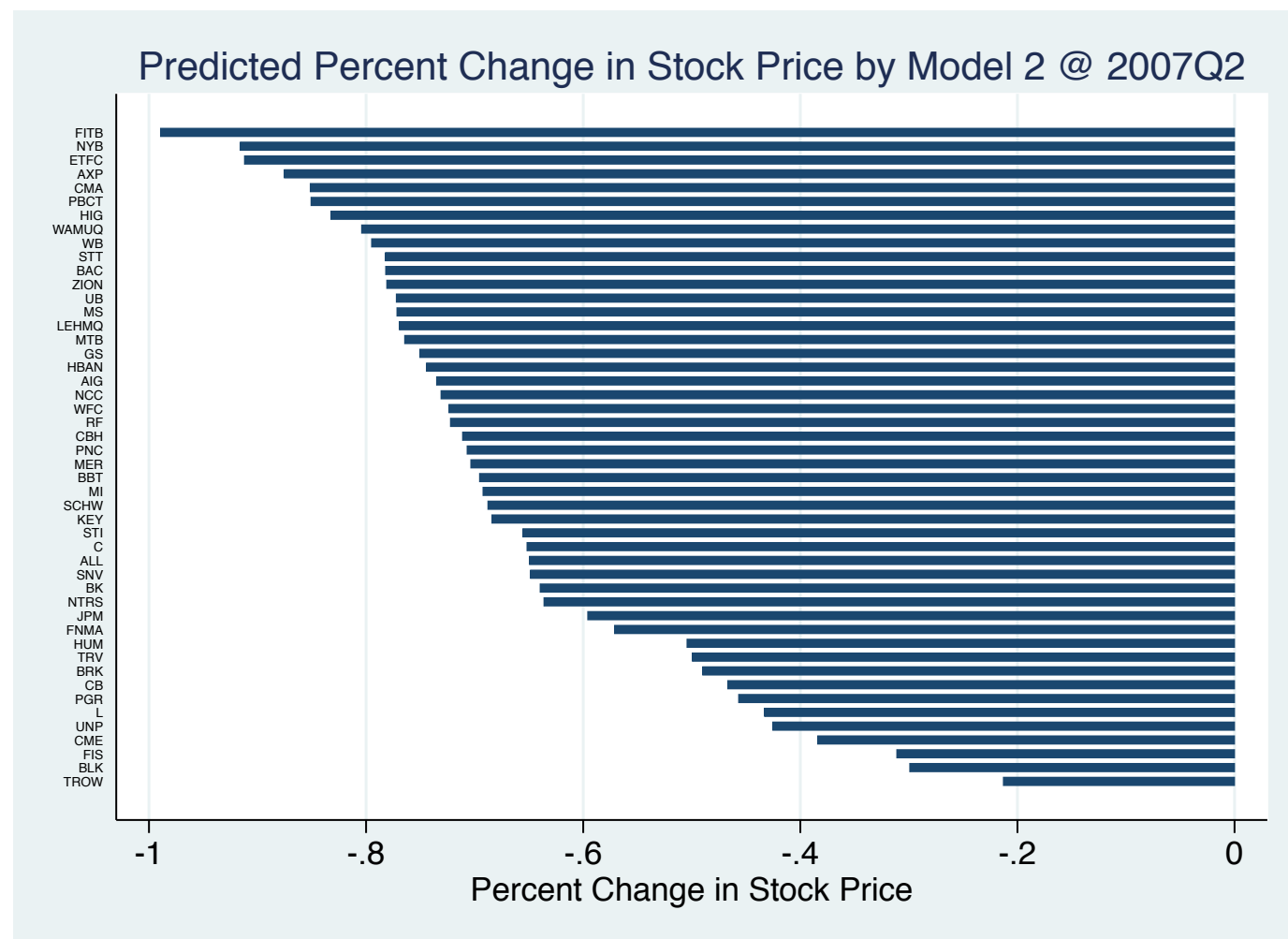


Figure 5.4: The predicted drops in stock market prices starting from the highest to the least according to Model 2 by the use of MFP Technique as of 2007Q3

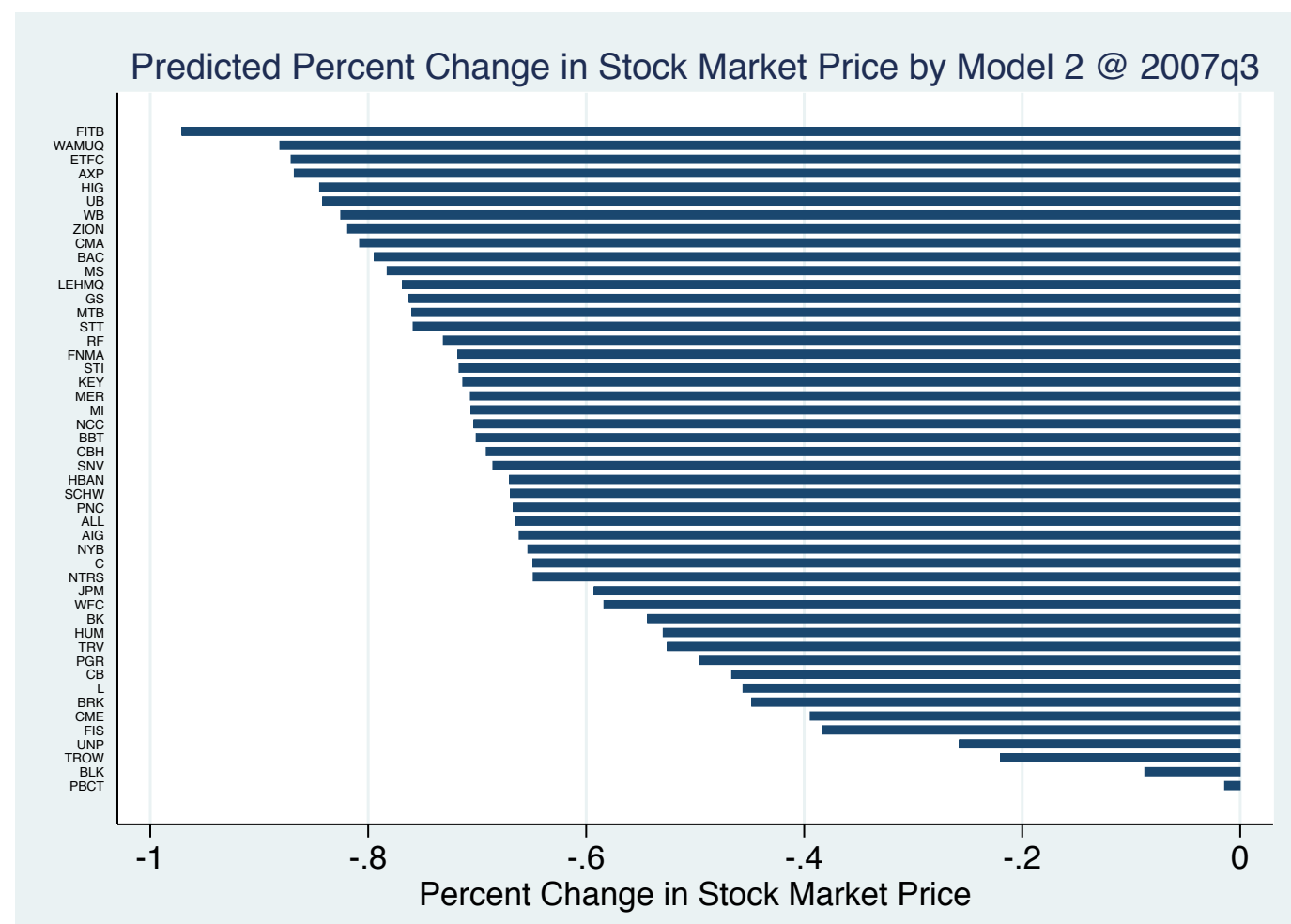




\section{APPENDIX F}

Table 6.1: This table shows the coefficients from Multivariable Fractional Polynomials Techniques forecasting the percent change in stock market price between min- and max-point (2010q2 - 2011q1) based on one-year, two-years, and three-years lags of financial institutions characteristics.

\begin{tabular}{lccc}
\hline $\begin{array}{l}\text { Dependent } \\
\text { Variable }\end{array}$ & \multicolumn{1}{l}{ Y1 } \\
\hline $\begin{array}{l}\text { Significant } \\
\text { Financial } \\
\text { Variables }\end{array}$ & Four Quarters Lag & Eight Quarters Lag & Twelve Quarters Lag \\
& & & \\
$f(\mathrm{Cr})$ & $0.1159^{* * *}$ & $0.1180^{* * *}$ & $0.1152^{* * *}$ \\
& $(0.02)$ & $(0.02)$ & $(0.02)$ \\
Constant & $0.1869^{* * *}$ & $0.1869^{* * *}$ & $0.1869^{* * *}$ \\
& $(0.02)$ & $(0.02)$ & $(0.02)$ \\
Obs. & 45 & 45 & 45 \\
$R^{2}$ & 0.4281 & 0.4364 & 0.4314 \\
\hline
\end{tabular}

Note: ${ }^{*} p<0.05 ;{ }^{* *} p<0.01 ;{ }^{* * *} p<0.001$

Standard errors in parenthesis

Dependent Variables: the percent change in stock market price between min- and max-point (2010q2 - 2011q1)

Independent Variables: every model starts with the total of 17 independent variables over the same lag to end up with the selected significant variables as shown in the table above in the transformed forms as presented in the equation (7). 
Figure 6.1: Average Level of Current Ratio versus Y1 (Out-of-Sample Test)

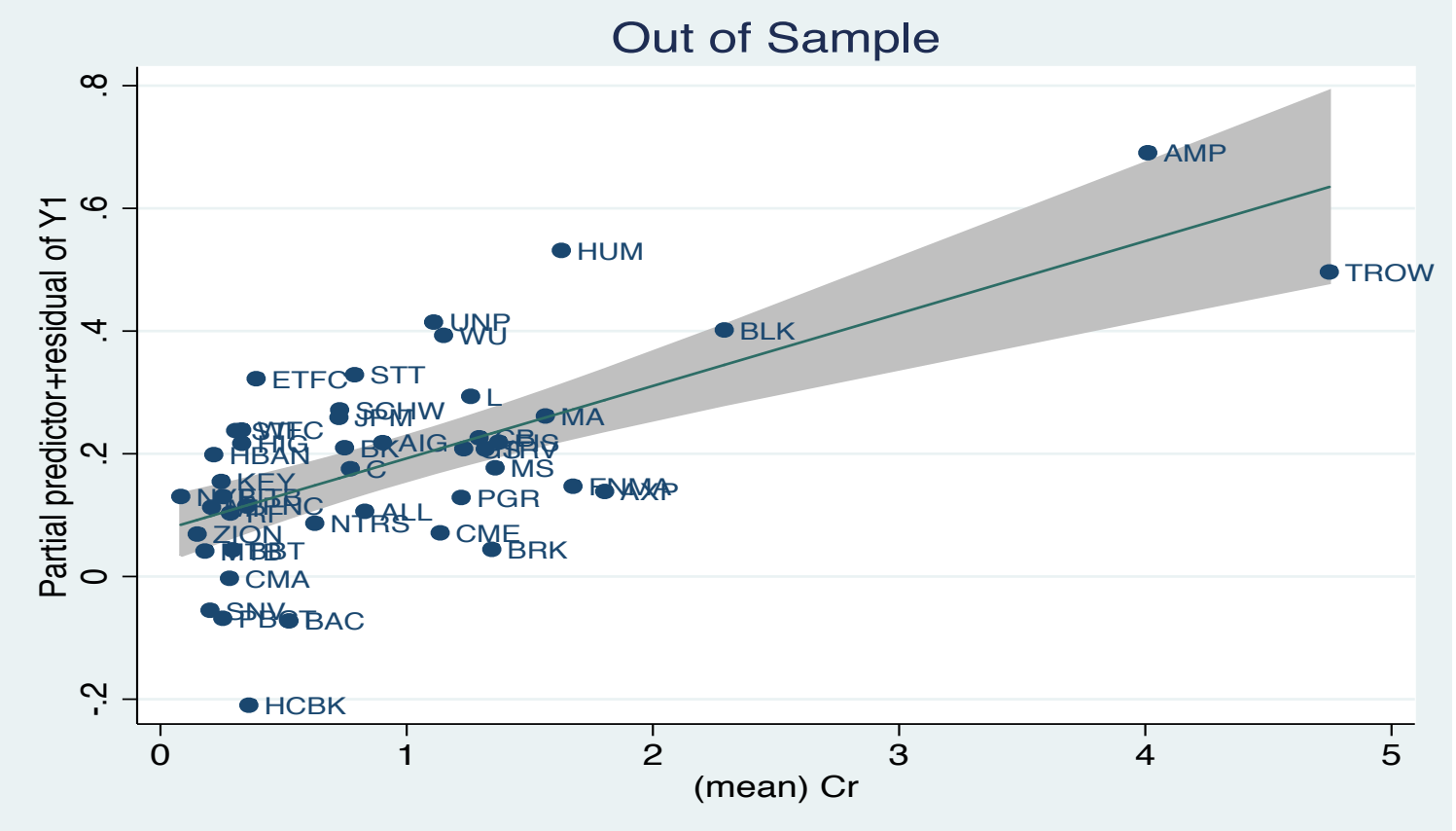




\section{REFERENCES}

Acharya, Viral V., Pedersen, Lasse H., Philippon, T., and Richardson, Matthew. "Measuring Systemic Risk." Working Paper, New York University, 2010.

Adrian, Tobian and Brunnermeier, Markus K. "CoVaR." Working Paper, 2011.

Altman, E., Haldeman, R. and Narayanan, P. "ZETA Analysis: A New Model to Identify Bankruptcy Risk of Corporations." Journal of Banking and Finance, Jan 1977.

Altman, Edward I. "Financial Ratios, Discriminant Analysis and the Prediction of Corporate Bankruptcy." Journal of Finance, September 1968.

Angkinand, Apanard P., Wihlborg, Clas \& Willett, Thomas D. "Market Discipline for Financial Insititutions and Markets for Information." In Forthcoming in Research Handbook on International Banking and Governance, by Chen Lin and Clas Wihlborg (Eds.) James R. Barth. Edward Elgar, 2011.

Beaver, W. "Financial Ratios as Predictors of Failures ." Journal of Accounting Research , January 1967.

Beck, T., Demirguc-Kunt, A., and Levine, R. "Bank concentration, competition, and crises: First result." Journal of Banking and Finance 30 (2006): 1581-1603.

Beltratti, A., and Stulz, R. M. "Why did some banks perform better?" Journal of Financial Economics 105 (2012): 1-17.

Bentler, P. M. "Comparative Fit Indexes in Structural Models." Psychological Bulletin, 1990: 238-246.

Berger, Allen N. \& Bouwman, Christa H. S. "Bank Capital, Survival, and Performance around Financial Crisis." 2009.

Black, G. and Scholes, M. "The Pricing of Options and Corporate Liabilities." Political Economics 81, no. 3 (1973): 637-654.

Blundell-Wignall, Adrian and Roulet, Caroline. "Business models of banks, leverage and the distance-to-default." OECD Journal:Financial Market Trends, January 2013.

Bodie, Zvi, Kane, Alex, \& Marcus, Alan J. Investments. 5th. Mc Graw-Hill Irwin, 2001.

Bollen, Kenneth A. and Long, J. Scott. Testing Structural Equation Models. SAGE Focus. Vol. 154. ISBN 0-8039-4507-8 vols. 1993.

Boyd, J. H., De Nicolo, G., and Smith, B. "Crises in competitive versus monopolistic banking systems." Journal of Money, Credit and Banking 36 (2004): 487-506. 
Browne, M. W., and Cudeck, R. "Alternative ways of assessing model fit." In Testing Structural Equation Models, edited by K. A. Bollen and J. S. Long, 136-162. Newbury Park, CA: Sage, 1993.

Brunnermeier, M., Dong, G., and Palia, D. "Banks' non-interest income and systemic risk." Working Paper, 2012.

Burmeister, E. and McElroy, M.B. "Joint Estimation of Factor Sensitivities and Risk Premia for the Asset Pricing Theory ." Journal of Finance 43 (1988): 721-733.

Calomiris, C. W., and Kahn, C.M. "The role of demandable debt in structuring optimal banking arrangements." American Economic Review, 1991: 497-513.

Caprio, G., Demirguc-Kunt, A. and Kane, E. "The 2007 Meltdown in Structured Securitization: Searching for Lessons, not Scapegoats." The World Bank Research Observer, 2010: 125-155.

Chen, N., Roll, R., Ross, S.A. "Economic Forces and the Stock Market." Journal of Business 59, no. 3 (July 1986): 383-403.

Deakin, E. B. "A Discriminant Analysis of Predictors of Business Failure." Journal of Accounting Research, March 1972.

Demirguc-Kunt, A., Detragiache, E. \& Merrouche, O. "Bank Capital: Lessons from the Financial Crisis." IMF Working Paper, The International Monetary Fund, 2010.

Diamond, D. W. "Financial intermediation and delegated monitoring." 1984: 393-414.

Diamond, D. W., and Rajan, R. G. "Liquidity risk, liquidity creation and financial fragility: A theory of banking ." Journal of Political Economy 109 (2001): 287-327.

Fama, Eugene F. and French, Kenneth R. "The Cross-section of Expected Stock Return." Journal of Finance 47, no. 2 (1992): 427-465.

Freixas, X. and Rochet, J. Microeconomics of Banking. 2nd Edition. London: MIT Press, 2008.

French, Craig W. "The Treynor Capital Asset Pricing Model." Journal of Investment Management 1, no. 2 (2003): 60-72.

Gregor N. F. Weib, Denefa Bostandzic, and Sascha Neumann. "What factors drive systemic risk during international financial crises? ." May 17, 2013.

Gujarati, Damodar. Basic Econometrics. 4th. McGraw-Hill, 2002.

Haldane, Andrew G. "The Dog and the Frisbee." Bank of Englan, 2012. 
Hartmann, P., S. Straetmans, and C. G. De Vries. "Asset Market Linkages in Crisis periods." Review of Economics and Statistics 86, no. 1 (2004): 313-326.

Heine, Max L. "Predicting Financial Distress of Companies." Stern School of Business, New York University, 2000.

Investor.com, Contrary. "The Mistakes Of Our Grandparents?" Contrary Investor.com. February 2004.

Matutes, C. and Vives, X. "Imperfect competition, risk taking, and regulation in banking." European Economic Review, 2000: 1-34.

Merrouche, Ouarda and Nier, Erland. "What Caused the Global Financial Crisis? Evidence on the Drivers of Financial Imbalances 1999-2007." IMF Working Paper, IMF, 2010.

Merton, R. "Theory of Rational Option Pricing." Economic Management 4 (1973): 141 183.

O'Brien, Robert M. Quality \& Quantity. Vol. 41. 2007.

Papa, Vincent T. and Peters, Sandra J. "User Perspectives on Financial Instrument Risk Disclosures Under International Financial Reporting Standards." CFA, 2011.

Ramsey, J. B. "Test for specification errors in classical linear least-squares regression analysis." Journal of the Royal Statistical Society 31, no. B (1969): 350-371.

Royston, P., and Altman, D. G. "Regression using fractional polynomials of continous covariates." Journal of the Royal Statistical Society (Series A) 43, no. 3 (1994): 429467.

Sauerbrei, W., and Royston, P. "Building Multivariables Prognostic and Diagnostic Models." Journal of the Royal Statistical Society (Series A) 162, no. 1 (1999): 71-94.

Stadtmuller, R. Schimdt and U. "Nonparametric estimation of tail dependence." Scandinavian Journal of Statistics 33 (2006): 307-335.

Vinals, J., Fiechter, J., Pazarbasioglu, C., Kodres, L., Narain, A., and Moretti, M. "Shaping the New Financial System." IMF Staff Position Note, Monetary and Capital Markets Department, IMF, 2010.

Willett, T. "The Role of Defective Mental Models in the Global Financial Crises." Journal of Financial Economic Policy 4, no. 1 (2009): 41-57. 